\title{
TRANSFERÊNCIA DO GENE atacina A PARA PLANTAS DE MARACUJÁ AMARELO (Passiflora edulis Sims f. flavicarpa Deg.) POR BIOBALÍSTICA
}

\author{
ELIZABETE KEIKO TAKAHASHI
}

Tese apresentada à Escola Superior de Agricultura "Luiz de Queiroz", Universidade de São Paulo, para obtenção do título de Doutor em Agronomia, Área de Concentração: Genética e Melhoramento de Plantas.

P I R A C I C A B A

Estado de São Paulo - Brasil

Julho - 2002 


\title{
TRANSFERÊNCIA DO GENE atacina A PARA PLANTAS DE MARACUJÁ AMARELO (Passiflora edulis Sims f. flavicarpa Deg.) POR BIOBALÍSTICA
}

\author{
ELIZABETE KEIKO TAKAHASHI \\ Bióloga
}

Orientadora: Profa. Dra. MARIA LÚCIA CARNEIRO VIEIRA

Tese apresentada à Escola Superior de Agricultura "Luiz de Queiroz", Universidade de São Paulo, para obtenção do título de Doutor em Agronomia, Área de Concentração: Genética e Melhoramento de Plantas.

\author{
PIR A C I C A B A \\ Estado de São Paulo - Brasil \\ Julho - 2002
}




\section{Dados Internacionais de Catalogação na Publicação (CIP)}

DIVISÃO DE BIBLIOTECA E DOCUMENTAÇÃO - ESALQ/USP

Takahashi, Elizabete Keiko

Transferência do gene atacina a para plantas de maracujá amarelo (Passiflora edulis

Sims f. Flavicarpa Deg.) por biobalística / Elizabete Keiko Takahashi. - - Piracicaba, 2002.

137 p. : il.

Tese (doutorado) - Escola Superior de Agricultura Luiz de Queiroz, 2002.

Bibliografia.

1. Bacteriose vegetal 2. Biolística 3. Maracujá 4. Resistência genética vegetal 5.

Transferência de genes I. Título

CDD 634.425

"Permitida a cópia total ou parcial deste documento, desde que citada a fonte O autor" 
Meus pais,

Keiji Takahashi (In memoriam)

Shinobu Takahashi

e ao Adhemar

Com amor,

Dedico 


\section{AGRADECIMENTOS}

Quero agradecer a todos de uma forma direta ou indiretamente tornaram possível a realização desta tese e, especialmente:

À Escola Superior de Agricultura "Luiz de Queiroz" (ESALQ), particularmente ao Departamento de Genética,

Ao Conselho Nacional de Desenvolvimento Científico e Tecnológico CNPq, pela concessão da bolsa de estudo durante o curso.

À Profa Dra. Maria Lúcia Carneiro Vieira pela orientação, confiança, sugestões e apoio durante toda a etapa da realização deste trabalho.

À Profa. Dra. Beatriz Appezzato-da-Glória, do Departamento de Ciências Biológicas de ESALQ, por colocar o laboratório à disposição para realização das análises histológicas e pelo auxílio na documentação fotográfica.

Ao Prof. Dr. Márcio de Castro Silva e Filho pelas valiosas sugestões, apoio constante e por colocar o seu laboratório à disposição.

Ao Dr. Luiz Gonzaga Esteves Vieira e ao Dr. Luiz Filipe Pereira pelas valiosas sugestões e discussões constantes, apoio e amizade.

Aos professores pelo ensinamento e sabedoria.

À Dra. Vera Maria Quecini, Dra. Maria Cristina Falco e ao Dr. Adilson Kenji Kobayashi, pelas constantes sugestões, críticas e amizade durante todas as fases do trabalho.

Aos companheiros do Programa de Pós-Graduação em Genética e Melhoramento de Plantas pelo incentivo e apoio constante nessa nossa caminhada. 
Aos funcionários do Departamento de Genética pelo apoio e amizade.

Aos meus amigos, minha família em Piracicaba, em especial: Adriano, Alessandra, Américo, Aurélio, Carlinhos, Fernando, Frederico, Juliana, Juliano, Lucianinha, Maria Imaculada, Maria Rita, Maria Teresa, Mariza, Michel, Monalisa, Ricardo, Salete, Silvana, pela constante amizade e apoio que foram para mim um estímulo e um exemplo a seguir.

À secretária Léia pela dedicação ao seu trabalho, pela eficiência e paciência, e principalmente pelo apoio constante.

À bibliotecária Silvana pelo apoio, pela paciência e confiança, e principalmente pela amizade.

Ao Adhemar pela amizade, companheirismo, compreensão imensurável, paciência, carinho e amor que me dedicou desde o início, principalmente na fase final da tese.

À minha família pela amizade, amor, compreensão e carinho que sempre me dedicou.

A DEUS por tudo. 


\section{SUMÁRIO}

Página

LISTA DE FIGURAS .......................................................................... ix

LISTA DE TABELAS ....................................................................

LISTA DE ABREVIATURAS E SÍMBOLOS........................................... xiv

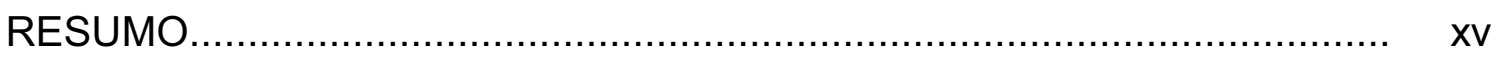

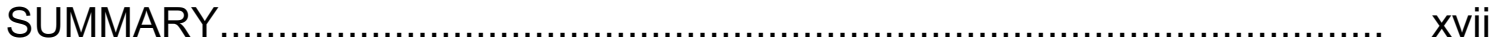

1 INTRODUÇÃO

2 REVISÃO DE LITERATURA............................................................

2.1 A cultura do maracujazeiro ........................................................ 3

2.2 Bacteriose: um problema da cultura do maracujazeiro......................... 5

2.3 Melhoramento de maracujazeiro para resistência à bacteriose.............. 8

2.4 Morfogênese vegetal................................................................ 9

2.4.1 Organogênese in vitro............................................................... 11

2.4.2 Cultura de tecidos do gênero Passiflora........................................... 15

2.5 Marcadores seletivos em transformação de plantas.............................. 18

2.6 Transformação genética de plantas por bombardeamento de partículas

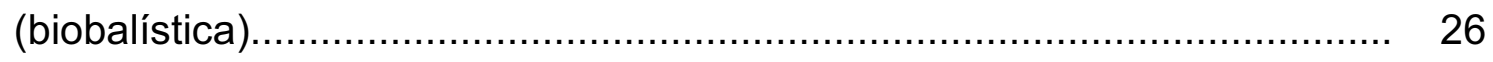

2.6.1 Transformação genética em espécies frutíferas.............................. 31 
2.7 Estratégias para obtenção de resistência à bacteriose através da engenharia genética e expressão de proteínas heterólogas antibacterianas.

2.8 Atacinas como agentes bactericidas............................................. 35

2.8.1 Transformação de plantas com o gene da atacina............................ 37

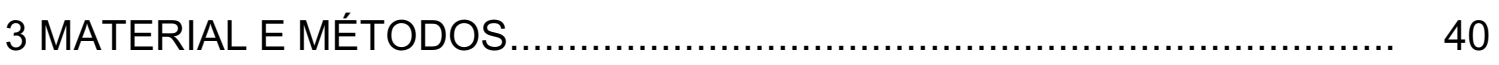

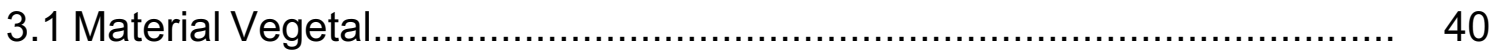

3.2 Morfogênese in vitro.............................................................. 41

3.2.1 Organogênese direta............................................................... 41

3.2.2 Organogênese indireta........................................................ 42

3.2.3 Análises histológicas das estruturas diferenciadas a partir de hipocóticos e segmentos entrenodais.............................................. 42

3.2.4 Análises ultra-estruturais da organogênese indireta.......................... 43

3.3 Agente seletivo ..................................................................... 43

3.4 Construção do vetor de expressão................................................. 44

3.4.1 Etapa 1- Construção de pFFatacina.............................................. 44

3.4.2 Etapa 2- Construção de pCatacina 1300 e pCatacina 2300................ 45

3.4.3 Cepas bacterianas................................................................... 46

3.4.4 Análise dos transformantes bacterianos ("Screening" por PCR).......... 46

3.5 Construção dos oligonucleotídeos iniciadores ("primers")..................... 47

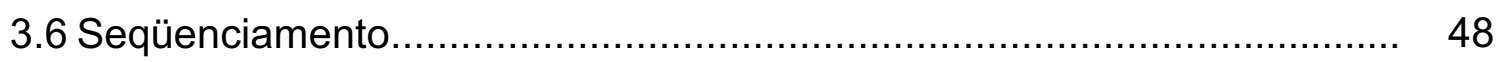

3.7 Plasmídeos....................................................................... 49

3.8 Transformação por biobalística.................................................. 50

3.9 Ensaio histoquímico de GUS ..................................................... 52

3.9.1 Localização anatômica da expressão transiente do gene uidA........... 52

3.10 Análise molecular dos transformantes primários por reação em cadeia da polimerase (PCR) .................................................................. 52

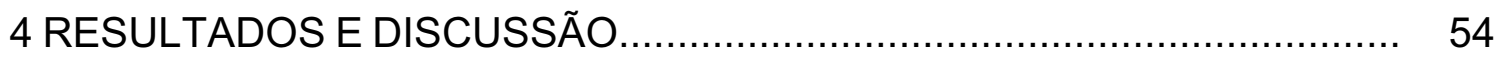

4.1 Obtenção do material vegetal....................................................... 54

4.2 Morfogênese in vitro................................................................ 54 


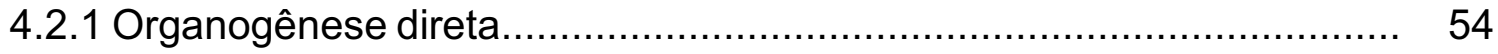

4.2.2 Organogênese indireta......................................................... 60

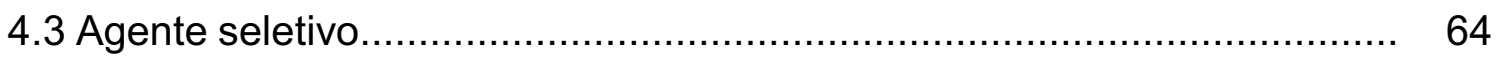

4.4 Construção dos cassetes de expressão............................................ 69

4.4.1 Etapa 1: Construção do vetor pFFatacina........................................ 69

4.4.2 Etapa 2: Construção do vetor pCatacina 1300 e pCatacina 2300........ 76

4.5 Transformação por biobalística........................................................ 83

4.5.1 Otimização dos parâmetros para transformação do maracujazeiro por biobalística analisada pela expressão transiente de uidA.......................... 83

4.5.1.1 Parâmetros biológicos.............................................................. 83

4.5.1.2 Parâmetros físicos....................................................................... 87

4.6 Transformação de maracujazeiro com o gene atacina A...................... 90

4.6.1 Co-bombardeamento utilizando 2 plasmídeos................................. 90

4.6.2 Bombardeamento utilizando um único plasmídeo................................ 94

4.6.3 Síntese dos experimentos de transformação e perspectivas

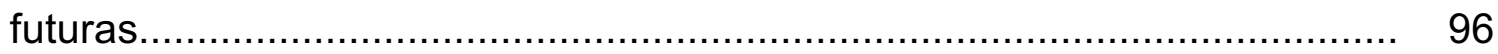

4.6.4 Maracujá transgênico: riscos e recomendações................................ 98

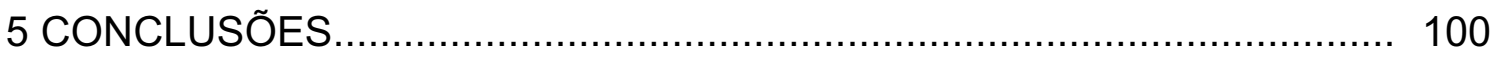

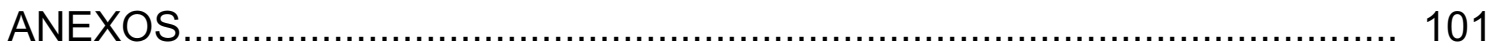

REFERÊNCIAS BIBLIOGRÁFICAS ................................................. 107 


\section{LISTA DE FIGURAS}

Página

1 Esquema hipotético de organogênese in vitro de Arabidopsis

2 Construções utilizadas para transformação de maçã ("Galaxy" e M.26) mediada por Agrobacterium tumefaciens (EHA105)

3 Germinação de sementes de Passiflora edulis Sims f. flavicarpa Deg., população Sul Brasil.....

4 Resposta organogênica a partir de discos foliares de Passiflora edulis Sims f. flavicarpa Deg., população Sul Brasil, sob tratamento fatorial....

5 Organogênese direta a partir de disco foliar de Passiflora edulis Sims f. flavicarpa Deg., população Sul Brasil................................................

6 Organogênese indireta a partir de segmentos entrenodais de P.edulis Sims f. flavicarpa Deg.

7 Cortes histológicos (A, B, C, D e E) e microscopia eletrônica de varredura $(F$ e $G$ ) de segmentos entrenodais de Passiflora edulis Sims f. flavicarpa Deg. aos 18 dias de cultura em meio MSB(A). 
8 Discos foliares de $P$. edulis Sims f. flavicarpa Deg. cultivados em meio $\operatorname{MSB}(A)$ suplementado com diferentes concentrações (em mg/L) de antibióticos ou herbicida (fosfinotricina), após 7 dias no escuro $(A)$ e após 28 dias sob luz $(\mathrm{B})$

9 Seqüência do gene atacina $A$ isolado de Trichoplusia ni.

10 Alinhamento das sequências do gene atacina $A$ de Trichoplusa ni utilizando o programa "Clustal X (1.81) Multiple Sequence Alignment"..

11 Construção do vetor pFFatacina (Etapa 1)

12 Construção dos vetores pCatacina 1300 e pCatacina 2300 (Etapa 2)... 77

13 Caracterização dos vetores pCatacina 1300 e pCatacina 2300

14 Caracterização dos vetores por enzimas de restrição

15 Mapas de restrição dos vetores, obtidos por clivagem com EcoRI, Xhol, HindIII, e combinação entre elas (em pb).

16 Caracterização da transferência dos vetores pCatacina 1300 e pCatacina 2300 para Agrobacterium tumefaciens: estirpes EHA105 (A) e LBA 4404 (B)

17 Expressão transiente de GUS em diferentes explantes e idades de cultura de $P$. edulis Sims f. flavicarpa Deg. 
18 Expressão transiente de GUS, utilizando os vetores pBI426 e

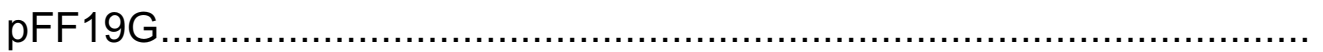

19 Seleção e regeneração de plantas de $P$. edulis Sims f. flavicarpa Deg. em meio $\operatorname{MSB}(A) K(A-C)$, e análise por $P C R$ das plantas transgênicas para o gene atacina $A$ de Trichoplusia ni (D-E) 


\section{LISTA DE TABELAS}

Página

1 Sumário dos efeitos de vários agentes seletivos e os genes de resistência correspondentes

2 Principais culturas transgênicas e os genes introduzidos......

3 Seqüência de oligonucleotídeos iniciadores ("primers") construídos visando às análises por PCR.

4 Seqüência de oligonucleotídeos iniciadores ("primers") utilizados nas análises por PCR para análises da transgenia.

5 Análise conjunta da resposta organogênica em relação aos recipientes utilizados

6 Regeneração, expansão e morte de discos foliares de Passiflora edulis f. flavicarpa Deg., população Sul Brasil, em resposta a diferentes concentrações dos agentes seletivos: higromicina, canamicina, geneticina e fosfinotricina

7 Expressão transiente de GUS (número de pontos azuis) em função da a pressão de gás Hélio (psi) e distância de vôo das micropartículas até o alvo $(\mathrm{cm})$ em calos e discos foliares de $P$. edulis Sims $\mathrm{f}$. 


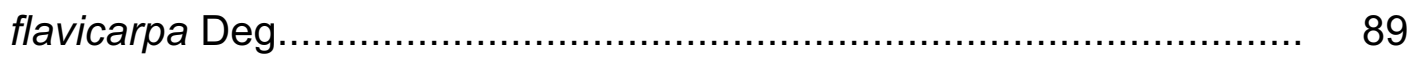

8 Resumo dos resultados de co-transformação com os vetores pBI426/pFFatacina e análise molecular de plantas transgênicas por

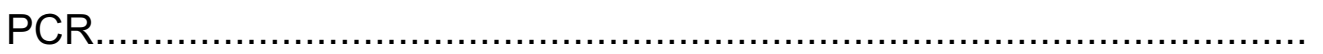

9 Resumo dos resultados de transformação com o vetor pCatacina 1300 e análise molecular de plantas transgênicas por PCR.................

10 Resumo geral de transformação por biobalística com o gene atacina $A$ (pFFatacina e pCatacina 1300)..................................................... 97 


\section{LISTA DE SIGLAS, ABREVIATURAS E SÍMBOLOS}

MS - meio MS (Murashige \& Skoog, 1962)

BA - benzilaminopurina

MSB(A) - meio MS contendo $0,5 \mathrm{mg} / \mathrm{L}$ de BA, $5 \%$ de água de coco, solidificado

com $0,6 \%$ de agar

$\mathrm{MSB}(\mathrm{A}) \mathrm{K}$ - meio $\mathrm{MSB}(\mathrm{A})$ contendo canamicina

$\operatorname{MSB}(\mathrm{A}) \mathrm{H}$ - meio $\mathrm{MSB}(\mathrm{A})$ contendo higromicina

PPT - fosfinotricina

PCR - reação em cadeia da polimerase

GUS - $\beta$-glucuronidase

EDTA - ácido etileno diamino tetracético

TRIS - tris-(hidroximetil)-aminometano

TE - tampão Tris-EDTA.

MCS - sítio de clonagem múltipla 


\title{
TRANSFERÊNCIA DO GENE atacina A PARA PLANTAS DE MARACUJÁ AMARELO (Passiflora edulis Sims f. flavicarpa Deg.) POR BIOBALÍSTICA
}

\author{
Autora: ELIZABETE KEIKO TAKAHASHI \\ Orientadora: Profa. Dra. MARIA LÚCIA CARNEIRO VIEIRA
}

\section{RESUMO}

O Brasil é o principal produtor de maracujá amarelo. Entretanto, a produtividade é baixa, cerca de $10.000 \mathrm{t}$ por hectare. A produção de frutos varia com o cultivar, condições climáticas, manejo e outros fatores, principalmente doenças causadas por bactérias e vírus. Metodologias de transformação genética são alternativas modernas para obter plantas resistentes. A proteína derivada de inseto, atacina A atua como bactericida, e tem sido utilizada para conferir resistência a espécies vegetais. Os objetivos do presente estudo foram (i) obter a regeneração de brotos in vitro, (ii) testar a eficiência de agentes seletivos durante o processo organogênico, (iii) construir o cassete contendo o gene atacina $A$, e (iv) determinar as condições físicas e biológicas para a transformação genética de plantas de maracujá amarelo utilizando o método de biobalística. Em relação a estudos in vitro, três recipientes de cultura foram avaliados como também diferentes concentrações de benzylaminopurina (BA) e água de coco que foram adicionadas ao meio basal. Phytagel e agar também foram testados como agentes solidificantes. As culturas foram avaliadas quanto à resposta morfogênica dos discos foliares. $O$ gene atacina $A$ foi sequenciado $e$ 
clonado para receber o promotor CaMV $35 \mathrm{~S}$ com um enhancer duplicado e o terminador $35 \mathrm{~S}$. Este vetor foi denominado pFFatacina. O cassete de expressão foi clonado nos vetores pCambia 1300 e pCambia 2300 que contêm os genes higromicina (hpt) e canamicina (nptll), respectivamente. Discos foliares, assim como segmentos entrenodais e hipocotiledonares que induzem calos, foram usados nos experimentos de biobalística. A expressão do gene uidA foi avaliada para testar os parâmetros de bombardeamento, pressão de gás Hélio (psi) e a distância da tela de retenção até o tecido alvo $(\mathrm{cm})$. A resposta organogênica dos discos foliares não diferiu quando placas de petri, tubos ou frascos foram usados, embora os tubos $(2,4 \times 8,5 \mathrm{~cm}, 30 \mathrm{ml})$ mostraram uma resposta ligeiramente melhor. O meio MS (Murashige \& Skoog, Physiologia Plantarum, 15,1962$)$ solidificado com agar $(0,6 \%)$ e suplementado com 0,5 $\mathrm{mg} / \mathrm{L}$ BA e $5 \%$ de água de coco $(\mathrm{w} / \mathrm{v})$ provou ser eficiente na indução de organgênese. Brotos foram obtidos após 30 dias. Segmentos entrenodais e hipocotiledonares produziram 300 estruturas semelhantes a gemas por explante. Microscopia de varredura e análises histológicas demonstraram ser estruturas foliares, as quais evoluíram em brotos após 50 dias em $1 / 2 \mathrm{MS}$. Higromicina a $5 \mathrm{mg} / \mathrm{L}$ provou ser um agente seletivo apropriado, inibindo organogênese em $60 \%$ dos explantes. Canamicina a $50 \mathrm{mg} / \mathrm{L}$ foi também efetiva. Calos morfogênicos de até 10 dias e discos foliares de 3 dias de cultivo mostraram elevados níveis de expressão transiente sob $800 / 6,5$ ou 1000/9,5 (psi de gás Hélio/cm de distância de vôo dos microprojéteis). Foram realizados experimentos de co-transformação com pBI426 $(8,7 \mathrm{~kb})$ que contém o gene nptll e pFFatacina $(5,25 \mathrm{~kb})$, como também utilizando-se um único vetor (pCatacina 1300). Freqüência de transformação estável de $0,85 \%$ foi obtida. A integração do transgene foi confirmada por PCR para o gene atacina A. Este é o primeiro trabalho que relata a transferência de um gene de interesse para plantas de maracujá amarelo por biobalística. 


\title{
Attacin A GENE TRANSFERENCE TO PLANTS OF YELLOW PASSION FRUIT (Passiflora edulis Sims f. flavicarpa Deg.) BY BIOLISTICS
}

\author{
Author: ELIZABETE KEIKO TAKAHASHI \\ Adviser: Profa. Dra. MARIA LÚCIA CARNEIRO VIEIRA
}

\section{SUMMARY}

Brazil is the leading producer of the yellow passion fruit. However, the productivity is fairly low, about 10,000 t per hectare. Fruit yields vary with cultivars, climatic conditions, management and other factors, namely bacterial and virus diseases. Genetic transformation methodologies are modern alternatives to obtain plant resistance. The insectderived protein, attacin $\mathrm{A}$ acts as bactericide, and it has been used to confer resistance to plant species. The objectives of the present study were (i) to obtain in vitro shoot regeneration, (ii) to test the efficiency of certain selective agents during the organogenesis process, (iii) to construct the cassette containing the attacin $A$ gene, and (iv) to determine the physical and biological conditions for genetic transformation of passion fruit plants by using the biolistic approach. Regarding the in vitro studies, three culture recipients were evaluated as well as different concentrations of benzylaminopurine (BA) and coconut water that supplemented the basal medium. Phytagel and agar were also tested as solidifying agents. Cultures were evaluated with respect to leaf discs morphogenic responses. The attacin $A$ gene was sequenced, and cloned to 
receive the CaMV 35 S promoter with a duplicated enhancer sequence, and the $35 \mathrm{~S}$ terminator. This vector was denoted pFFatacina. The cassette was cloned in pCambia 1300 and pCambia 2300 vectors that contain the hygromicin (hpt) and kanamycin (nptll) genes, respectively. Leaf discs, as well as internodal segments and hypocotyl-derived sections chosen to induce calli, were used in the biolistic experiments. The uidA gene expression was evaluated for testing bombardment parameters, namely the helium pressure (psi) and the distance from the stopping screen to the target tissue $(\mathrm{cm})$. The organogenic response of the leaf discs did not differ when petri dishes, tubes or culture vessels were used although the tubes $(2,4 \times 8,5 \mathrm{~cm}, 30 \mathrm{ml}$ capacity) showed to be slightly better. The agar (0.6\%)-solidified MS (Murashige \& Skoog, Physiologia Plantarum, 15, 1962) medium supplemented with $0.5 \mathrm{mg} / \mathrm{L}$ BA and $5 \%(\mathrm{w} / \mathrm{v})$ coconut water proved to be efficient to induce organogenesis. Shoots were obtained after 30 days. Internodal and hypocotyl-derived segments produced 300 bud-like structures per explant. Scanning microscopy and histological analyses provided evidences that they were leaf structures, which last 50 days in $1 / 2$ MS to evolve into shoots. Hygromicin at $5 \mathrm{mg} / \mathrm{L}$ proved to be proper as selective agent, inhibiting organogenesis in $60 \%$ of the explants. Kanamycin at $50 \mathrm{mg} / \mathrm{L}$ was also effective. Morphogenic calli up to 10 days old and 3 d-leaf discs showed high levels of transient uidA gene expression under $800 / 6.5$ or $1000 / 9.5$ helium pressure/distance from the stopping screen to the target tissue. Cotransformation experiments with pBI426 $(8.7 \mathrm{~kb})$ that contain the $n p t I$ gene and pFFatacina $(5.25 \mathrm{~kb})$ were carried on as well single vector transformation trials (pCatacina 1300). Stable transformation frequency of $0.85 \%$ was obtained. Transgene integration was confirmed by PCR for the attacin A gene. This is the first report on agronomically useful-gene transfer to yellow passion fruit plants by biolistics. 


\section{INTRODUÇÃO}

O gênero Passiflora compreende cerca de 24 subgêneros e 465 espécies (Vanderplank, 1996), sendo o Brasil o principal centro de diversidade genética. As espécies Passiflora edulis Sims. f. flavicarpa Deg. (maracujá amarelo) e $P$. edulis Sims. (maracujá roxo) são as mais cultivadas, com cerca de 44 mil hectares de área plantada em 1996. O Brasil também se destaca como o maior produtor mundial de maracujá, basicamente com pomares do tipo amarelo. A produção brasileira passou de 137,3 mil toneladas em 1996 para 317,15 mil toneladas em 1999 (FNP Consultoria \& Comércio, 2002).

A monocultura do maracujazeiro favoreceu o desenvolvimento de doenças, afetando consideravelmente a sua produção. Entre as doenças de maior relevância pode-se citar: morte prematura, murcha ou fusariose, bacteriose, antracnose, verrugose, septoriose, viroses e aquelas causadas por nematóides.

A bacteriose causada por Xanthomonas campestris. pv. passiflorae (Pereira, 1969) Dye tem se tornado um fator limitante para a expansão da cultura em diversas regiões do Brasil devido à forma severa com que ocorre sob condições de clima quente e úmido. Diversas medidas de controle dessa doença, como produção de mudas sadias, aplicação de produtos bactericidas não têm apresentado resultados satisfatórios. Consequentemente, a obtenção de materiais de maracujazeiro resistentes à bacteriose é a medida mais desejável para o seu controle.

O cultivo in vitro de células ou tecidos de maracujá amarelo está bem estabelecido, tendo sido relatada a otimização dos protocolos de organogênese 
direta, micropropagação, isolamento e cultivo de protoplastos com respectiva regeneração de plantas e suspensão celular embriogênica (Dornelas, 1995, Dornelas \& Vieira, 1994, Dornelas et al, 1995, Otoni, 1995; Passos, 1999, Biasi et al., 2000; Hall et al., 2000; Monteiro et al., 2000a e b; Barbosa et al., 2001; Reis, 2001). Devido à sua alta regenerabilidade, é possível a aplicação da tecnologia do DNA recombinante como ferramenta auxiliar ao melhoramento genético.

O presente trabalho teve como objetivo a otimização da organogênese in vitro para a população Sul Brasil, seleção de antibióticos e/ou herbicida como agentes seletivos, e transformação de plantas de $P$. edulis Sims. f. flavicarpa Deg. com o gene atacina $A$, que codifica o peptídeo atacina que tem propriedade bactericida. Foi utilizado o método direto de transformação (biobalística) visando obter resistência à bacteriose causada por Xanthomonas campestris. pv. passiflorae. 


\section{REVISÃO DE LITERATURA}

\subsection{A cultura do maracujazeiro}

A família Passifloraceae encontra-se largamente distribuída nos trópicos e inclui mais de 630 espécies, das quais a maior parte pertence ao gênero Passiflora e habita as regiões tropical e subtropical da América do Sul (Oliveira, 1987; Vanderplank, 1996). O gênero Passiflora compreende 24 subgêneros e 465 espécies, entre as quais cerca de 50 espécies produzem frutos comestíveis. A maioria das espécies do gênero Passiflora é oriunda das regiões Central e Norte do Brasil, com cerca de 150 espécies, considerado o principal centro de distribuição geográfica (Lopes, 1991). De outra parte, cerca de 20 espécies são originadas da Austrália, China, Malásia e Madagascar (Manica, 1997).

Apesar desse grande número de espécies, somente algumas têm importância econômica em função da qualidade dos frutos para consumo ou por apresentarem propriedades medicinais. As principais espécies que produzem frutos comestíveis são: $P$. edulis Sims f. flavicarpa Deg., $P$. edulis Sims, $P$. ligularis Juss., $P$. nitida (Kunth.), P. mollissima (HBK) Bailey, P. quadrangularis L., P. maliformis L., P. caerulea L., P. laurifolia Linn. e P. alata Dryand.

As duas formas de maracujá mais utilizadas comercialmente no mundo são o maracujá amarelo ( $P$. edulis Sims f. flavicarpa Deg.) e o maracujá roxo ( $P$. edulis Sims). No Brasil, o maracujá amarelo é mais adaptado a altitudes menores, e encontra-se nativo desde o Estado de Alagoas até o Paraná. O maracujá roxo é mais adaptado a maiores altitudes dos subtrópicos. 
À exceção da coloração dos frutos na maturação, as plantas das duas formas apresentam características e propriedades fisiológicas e morfológicas semelhantes.

Essas duas formas de maracujazeiro cruzam-se livremente e produzem descendentes férteis com características de coloração dos frutos intermediários aos genitores (Winks et al., 1988). Em alguns países, como na Austrália, a variedade roxa é mais cultivada por ser considerada superior em qualidade de suco e polpa. No Brasil, a variedade amarela é mais cultivada com vantagens sobre a roxa, como frutas maiores, maior produtividade, coloração mais atraente e suco mais ácido, permitindo à indústria maior flexibilidade para adição de açúcar (Bliska et al., 1994).

O Brasil é o maior produtor mundial de maracujá e entre os Estados mais produtivos destacam-se: Pará, Bahia, São Paulo, Minas Gerais e Sergipe (Meletti et al., 2000). Uma área de 44 mil hectares foi utilizada para produzir o maracujá no Brasil em 1996. A demanda de fruta comercial tem aumentado gradualmente. A produção brasileira passou de 137,3 mil toneladas em 1996 para 317,15 mil toneladas em 1999 (FNP Consultoria \& Comércio, 2002).

Os plantios comerciais são formados basicamente por maracujá amarelo que é responsável por $95 \%$ dos pomares brasileiros (Ruggiero et al., 1996; Meletti \& Maia, 1999).

A produção brasileira de maracujá amarelo tem sido destinada à produção de suco concentrado e à comercialização de frutas in natura. De acordo com estimativas da AFRUVEC (Associação dos Fruticultores da Região de Vera Cruz), baseadas na safra $1995 / 96$, aproximadamente $70 \%$ da produção paulista de maracujá é destinada ao consumo in natura e o restante é destinado à indústria. O Brasil, juntamente com Colômbia, Sri Lanka, Peru e Equador são os maiores exportadores de suco concentrado de maracujá (Ruggiero et al., 1996).

O Brasil possui excelentes condições ecológicas para o cultivo do maracujazeiro, mas a produtividade, de modo geral, ainda é baixa. Esse fato 
deve-se, principalmente, à falta de informações técnico-científicas e ao baixo nível tecnológico dos produtores no manejo da cultura na pré e pós-colheita (Melo et al., 2001). Oliveira \& Ferreira (1991) apontam a falta de um cultivar homogêneo e produtivo, tolerante às principais moléstias, como um entrave à qualidade e à produtividade dos pomares comerciais. Além disso, as variedades de maracujá comercial são, em sua maioria, suscetíveis a um grande número de pragas e doenças, além de pouco produtivas.

Os trabalhos de melhoramento genético ainda são escassos mas podem contribuir significativamente para o aumento da produtividade em função da grande variabilidade existente (Bruckner, 1997), e também para diminuir a oscilação na área plantada e conseqüente produção de frutos.

\subsection{Bacteriose: um problema da cultura do maracujazeiro}

As interações iniciais dos microrganismos com suas plantas hospedeiras são determinantes críticos no processo de infecção. No entanto, a maioria das infecções não leva à doença pois os microrganismos são, geralmente, repelidos por mecanismos de defesa de planta (Staskawicz et al., 2001).

Esses mecanismos de resposta induzidos pelas plantas sob ataque de patógeno, são de natureza estrutural e bioquímica. Entre eles estão (i) a síntese de enzimas hidrolíticas, tais como quitinase e $\beta$-glucanase e inibidores de proteinase; (ii) a modificação da parede celular por lignificação e acúmulo de calose, a $\beta$-1,3-glucan, e glicoproteínas ricas de hidroxiprolina (HRGPs); (iii) a síntese de fitoalexinas, compostos de baixo peso molecular com atividade antimicrobiana (Gualberto et al., 1989).

Staskawicz et al. (2001) relatam que uma etapa de vida epifítica (saprofítica) geralmente precede a entrada de bactérias fitopatogênicas na planta hospedeira, para então iniciar a patogenicidade. Por exemplo, os gêneros Pseudomonas e Xanthomonas podem colonizar as superfícies foliares 
de plantas e alcançar uma densa população bacteriana $\left(10^{7}\right.$ unidades formadoras de colônias (ufc) por $\mathrm{cm}^{2}$ ), sem causar doença. Sob determinadas condições ambientais, as bactérias entram no tecido vegetal através de aberturas naturais como estômatos, hidatódios ou ferimentos, caracterizando seu primeiro contato com o interior das células hospedeiras. As bactérias fitopatogênicas multiplicam-se nos espaços intercelulares (apoplasto) da célula, permanecendo também extracelularmente; diferentes de muitas bactérias patogênicas de células animais, as quais entram nas células hospedeiras e multiplicam-se intracelularmente (Staskawicz et al., 2001).

A bacteriose causada pela Xanthomonas campestris pv. passiflorae (Pereira, 1969) Dye, aumentou significativamente com a monocultura do maracujá. Essa bacteriose está entre os principais problemas fitossanitários que limitou a expansão dos maracujazeiros (Pereira, 1969; Yamashiro, 1987; Teixeira, 1994), pois essa doença tem se tornado um fator limitante para o seu cultivo em diversas regiões do Brasil devido à forma severa com que ocorre sob condições de clima quente e úmido (Yamashiro, 1980; Kuroda, 1981; Torres \& Ponte, 1994). A presença da bacteriose já foi relatada em todas as regiões produtoras de maracujá do Brasil (Kuroda, 1981; Teixeira, 1994).

Essa bactéria foi inicialmente denominada de Xanthomonas passiflorae. Mais tarde foi classificada por Dye et al. (1980), passando a ser denominada $X$. campestris pv. passiflorae, classificação em uso por vários autores (Takatsu, 2000). Gonçalves \& Rosato (2000), utilizando-se da técnica de hibridização DNA-DNA em 55 estirpes dessa bactéria, sugeriu uma nova designação: $X$. axonopodis pv. passiflorae. No presente trabalho a forma $X$. campestris pv. passiflorae será utilizada.

A transmissão do agente causal é feita pelo vento, por mudas contaminadas, caixas de colheita, ferramentas, utensílios, máquinas e sementes originárias de pomares contaminados (Meletti, 1999). A infecção ocorre através de aberturas naturais e lesões da planta, e resulta em invasão sistêmica como um todo. A bactéria ataca primeiramente as folhas. A infecção 
normalmente se estende para os feixes vasculares atingindo o pecíolo e ramo (Oliveira et al., 1988). As folhas doentes caem prematuramente e os ramos afetados secam e morrem (Pereira, 1969, Yamashiro, 1980). Os frutos também são atacados pela $X$. campestris pv. passiflorae. Os sintomas nos frutos são caracterizados pela formação de pequenas áreas verde-escuras e aquosas que evoluem para áreas circulares, oleosas e de cor pardacenta (Pereira, 1969; Teixeira, 1994). Os frutos afetados são impróprios para o comércio. Esta bactéria ataca as diferentes partes da planta em qualquer fase do seu desenvolvimento e a progressão vascular da doença normalmente leva a planta à morte.

Diversas medidas têm sido recomendadas para o controle da bacteriose, como a produção de mudas sadias, poda de limpeza e aplicação de produtos bactericidas (Teixeira, 1994; Torres \& Ponte, 1994; Yamashiro, 1980). Entretanto, essas medidas não têm apresentado resultados satisfatórios. Conseqüentemente, a obtenção de variedades de maracujazeiro resistentes à bacteriose é a medida mais desejável para o controle dessa doença.

Tem sido observada variação em Passiflora spp. na resposta à bacteriose causada por $X$. campestris. pv. passiflorae em estudos envolvendo diferentes acessos de Passiflora spp. As espécies $P$. molissima, $P$. cincinnata e P. foetida foram consideradas resistentes (Neto et al., 1984). P. maliformis também é considerada altamente resistente a essa doença (Kuroda, 1981). Em contraste, acessos de $P$. quadrangularis e $P$. alata são altamente suscetíveis (Neto et al., 1984). As formas amarelo e roxo de $P$. edulis têm se comportado como suscetíveis (Kuroda, 1981; Neto et al., 1984). A existência dessa variabilidade no germoplasma de Passiflora spp. abre possibilidade de obtenção de materiais comerciais resistentes, dependendo de um estudo mais amplo, detalhado e de um maior número de acessos a serem avaliados. 


\subsection{Melhoramento de maracujazeiro para resistência à bacteriose}

Com a intenção de explorar a variabilidade do germoplasma silvestre de Passiflora, Oliveira (1987) conduziu vários cruzamentos interespecíficos. Todavia, essa alternativa é bastante limitada em função de barreiras de incompatibilidade que existem entre as espécies de Passiflora, o que resulta na produção de poucas plantas híbridas com baixa ou nenhuma fertilidade, comprometendo assim seu aproveitamento em programas de melhoramento. Uma outra possibilidade para introgressão de genes a partir de espécies exóticas é a hibridação somática, via fusão de protoplastos. Esta técnica, por sua vez, além de laboriosa, requer um estudo detalhado que envolve a caracterização morfológica, estudo do comportamento meiótico e avaliações de natureza agronômica dos híbridos somáticos para delinear o seu potencial de aproveitamento em programas de melhoramento genético (Barbosa \& Vieira,1997; Vieira, 1997).

Wendland (1997) avaliou diferentes acessos de maracujá amarelo quanto à resposta $\mathrm{a} X$. campestris $\mathrm{pv}$. passiflorae e demonstrou a existência de diversos graus de resistência dentro da espécie. Assim, uma exploração mais refinada desta variabilidade permitirá uma melhor orientação aos programas de melhoramento, pois servirá para identificação de genótipos resistentes ou tolerantes à bacteriose.

Nakatani (2001) utilizou a população Sul Brasil de maracujá amarelo para avaliar a agressividade de 5 isolados de $X$. campestris pv. passiflorae, na qual discriminou os isolados mais agressivos. Esses isolados podem ser utilizados para discernir outros materiais resistentes e suscetíveis.

A construção de mapas de ligação tem importância no melhoramento genético pois permite a localização de genes envolvidos na produção e na resistência a patógenos e pragas, além de outros. Recentemente, Carneiro (2001) construiu o primeiro mapa genético em Passiflora edulis Sims f. flavicarpa com base em marcadores RAPD, utilizando a estratégia de 
mapeamento denominada "pseudo-testcross". Os genitores da população segregante para as marcas de RAPD são contrastantes quanto à resposta à inoculação por $X$. campestris pv. passiflorae, o que poderá ser útil para o mapeamento de genes de resistência nos grupos de ligação. Isso poderá facilitar procedimentos de seleção para resistência à bacteriose, assistida por marcadores moleculares.

Uma outra estratégia para se obter plantas resistentes, atualmente muito explorada, é a técnica de engenharia genética, em que um gene específico é diretamente introduzido em variedades elites. Essa estratégia tem sido empregada com sucesso em espécies frutíferas como a pera (Reynoird et al., 1999) e a maçã (Norelli et al., 1994; Ko et al., 2000), introduzindo-se genes que codificam proteínas bactericidas. Para o maracujazeiro, não há relato na literatura da utilização dessa estratégia. Sendo o controle e até a eliminação da bacteriose causada por $X$. campestris pv. passiflorae de extrema valia para a cultura, e de posse dos protocolos que precedem à geração de plantas transgênicas, isto é, de cultivo in vitro, justifica-se a importância da transferência molecular de genes para os maracujazeiros.

\subsection{Morfogênese vegetal}

A morfogênese vegetal é um processo complexo, em que a definição da forma e função dos tecidos da planta depende da habilidade da célula em se dividir e se diferenciar. Para uma célula entrar em divisão, manter-se competente para proliferação, tornar-se quiescente, expandir-se, diferenciar-se, ou entrar em apoptose, há vários sinais envolvidos, entre eles hormônios, nutrientes, luz e temperatura.

In vitro, células diferenciadas podem desdiferenciar-se para induzir à formação de embriões somáticos, brotos adventícios, ou raízes adventícias (Sugiyama, 2000). 
Sendo assim, a morfogênese in vitro também é dependente de vários fatores tais como: a) fonte, tamanho e idade do explante; b) condição fisiológica do órgão doador; c) condição ambiental na qual a planta doadora é mantida; d) o genótipo da planta (Vasil \& Thorpe, 1994).

Aspectos endógenos como (i) percepção/sinalização de fitohormônios; (ii) desdiferenciação celular para aquisição da competência; (iii) destino do processo, isto é, formação de um órgão específico ou embrião, são igualmente importantes no processo. O balanço hormonal inerente ao explante vai interagir com os estímulos ambientais fornecendo a resposta morfogênica. Todos estes componentes são essenciais e fundamentais para o desenvolvimento da planta in vitro (Passos, 1999; Sugiyama, 2000).

A morfogênese geralmente é controlada por fitorreguladores exogenamente suplementados, portanto, essa via é considerada dependente destes reguladores (Torres \& Caldas, 1990). Segundo Peres \& Kerbauy (1999), outro fator associado à competência organogenética, além da sensibilidade ao estímulo hormonal, seria o próprio metabolismo hormonal do explante, pois é ele que determinará, em última análise, o balanço hormonal endógeno para indução da organogênese. Desse modo, explantes com alta atividade de citocinina oxidase, enzima que degrada citocininas, podem não chegar a um balanço auxina/citocinina endógeno indutor da formação de gemas, memo que sejam adicionadas elevadas concentrações de citocininas ao meio de cultura. Finalmente, explantes comprometidos para vias particulares de desenvolvimento (elevada determinação para formar um órgão específico) podem falhar na alteração dessa via para assumir uma outra. Portanto, pode-se dizer que, quanto maior for a determinação de um explante para uma via de desenvolvimento (por exemplo, a formação de raízes), menor será a competência para formar outro tipo de órgão (por exemplo, gemas caulinares) (Peres, 2002). 
Pouco se conhece sobre os mecanismos chaves da morfogênese in vitro, de como os fitohormônios induzem à desdiferenciação e à morfogênese, assim como o fundamento da competência morfogenética.

\subsubsection{Organogênese in vitro}

Um dos notáveis feitos da pesquisa em fisiologia da organogênese in vitro foi a descoberta das citocininas e auxinas como determinantes no desenvolvimento de plantas in vitro (Skoog \& Miller, 1957). A proporção ou balanço auxina/citocinina em meio de cultura, há muito, é aceita como determinante para a resposta organogênica. Altas razões de auxina/citocinina geralmente induzem à formação de raiz, enquanto baixas proporções promovem à formação de brotos. Em meios com razões intermediárias de auxina/citocinina ocorre proliferação celular desorganizada, como calos.

Christianson \& Warnick $(1983,1984,1985)$ dividiram o processo de organogênese em 3 fases, baseados no requerimento temporal dos explantes no que tange ao balanço de fitorreguladores. Na primeira fase da organogênese, os explantes adquirem "competência" que é definida como a habilidade (não capacidade) de responder aos sinais de indução, como fitohormônios. Esta competência celular leva ao desenvolvimento de órgão específico, na segunda fase. Então, a morfogênese prossegue independentemente da suplementação por fitorreguladores na terceira fase. Essas fases são resumidas por Hicks (1994) e Ozawa et al. (1998) como: 'fase de aquisição de competência', 'fase de indução' (determinação), e 'fase de diferenciação morfológica'.

Se a competência é a habilidade de responder ao estímulo hormonal necessário à indução da formação do órgão, segundo Cary et al. (2001), a falha de competência de um tecido pode ser devida à falta de receptores para a classe hormonal que irá induzir o processo organogenético. Sendo assim, os recentes estudos relacionados com o isolamento de genes correspondentes a 
receptores, principalmente de citocininas, certamente contribuirão para um melhor entendimento do processo de aquisição de competência organogenética.

Embora os procedimentos para obtenção de organogênese in vitro variem entre espécies, em cultura de tecidos de Arabidopsis, por exemplo, a primeira fase é iniciada cultivando os explantes de hipocótilo ou raiz em meio de indução de calos (CIM) contendo 2,4-D. Em seguida, os explantes são cultivados em meio de indução de brotos (SIM) ou em meio de indução de raízes (RIM), os quais contêm uma taxa específica de fitorreguladores (Valvekens et al., 1988; Akama et al., 1992).

Três mutantes de Arabidopsis, srd1, srd2 e srd3 foram isolados e caracterizados para estudos de organogênese in vitro, incluindo o processo de desdiferenciação (Yasutani et al., 1994; Ozawa et al., 1998). Utilizando explantes radicular e hipocotiledonar excisados destes mutantes, concluiu-se que cada mutação srd afeta um estádio específico da organogênese adventícia, sendo que srd2 e srd3 interferem em eventos da fase de aquisição de competência. Entre os mutantes srd, srd2 é de particular interesse porque exibe, aparentemente, um fenótipo pleiotrópico, sendo que srd2 parece influenciar nas 3 fases do processo organogênico (Figura 1).

É indiscutível que as citocininas têm função predominante no processo organogênico. Já na década de 50, havia registros de que as citocininas induziam divisão celular, desenvolvimento de cloroplastos e formação de brotos (Skoog \& Miller, 1957). As citocininas atuam sinergicamente com as auxinas para induzir divisão celular e antagonicamente para promover à formação de brotos e raiz em culturas de calo (Skoog \& Miller, 1957). Parece razoável antecipar que os genes envolvidos na sinalização das citocininas possam regular a formação de brotos in vitro. Peres (2002) relata que os genes associados à capacidade de regeneração poderiam ser os próprios genes que codificam componentes da via de transdução de sinal ou as enzimas do metabolismo hormonal. Além disso, segundo o autor, para que um tecido se 
diferencie em um determinado órgão, faz-se necessário que ele possua a capacidade de expressão dos chamados "genes mestres", que coordenam a expressão dos vários genes que serão requeridos durante a organogênese.

Apesar da riqueza de informação em relação à propriedade química e fisiológica das citocininas, a transição das metodologias de caráter mais descritivo para molecular tem sido relativamente lenta comparada ao que ocorreu com outros hormônios, particularmente o etileno (Johnson \& Ecker, 1998; Kieber, 1997) e giberelina (Hedden \& Proebsting, 1999; Hooley, 1994; Swain \& Olszewski, 1996). Segundo Mok \& Mok (2001) isso ocorre pelo fato da ação de citocininas ser freqüentemente mascarada por interação com outros hormônios, os mutantes relacionados às citocininas não serem bem caracterizados, e da dificuldade em se distinguir mudanças metabólicas exclusivas à citocinina daquelas associadas à bioquímica das purinas (a citocinina é um derivado de adenina).

Kakimoto (1996) identificou o gene cki1, analisando mutantes de Arabidopsis, e sugeriu que ele tem uma função na detecção ou transdução de sinal (ou ambas) de citocininas. Quando o gene é superexpresso, na ausência de citocinina exógena, ocorre a formação de brotos e de calos esverdeados. Recentemente, genes para receptores de citocinina cre1/ahk4 foram identificados (Inoue et al., 2001; Ueguchi et al., 2001), os quais codificam para uma histidina quinase.

Estudos do genoma funcional de Arabidopsis também têm permitido a identificação de genes que podem estar envolvidos na organogênese in vitro, como esr1 (enhancer de genes relacionados à regeneração de brotos), cuja superexpressão confere a geração de brotos independente de citocinina, e também aumenta a eficiência de regeneração de brotos, na presença de citocinina (Banno et al., 2001). Os autores sugerem que os efeitos de esr1 na regeneração de brotos agem sinergicamente com aqueles de citocinina, e são específicos para a formação de brotos, já que esr1 não pode induzir à formação de calos ou à formação de raiz. Os resultados observados na expressão de 
esr1 em culturas de Arabidopsis suportam a hipótese lançada por Christianson \& Warnick $(1983,1984,1985)$ de que a organogênese de novo é formulada por 3 fases distintas.

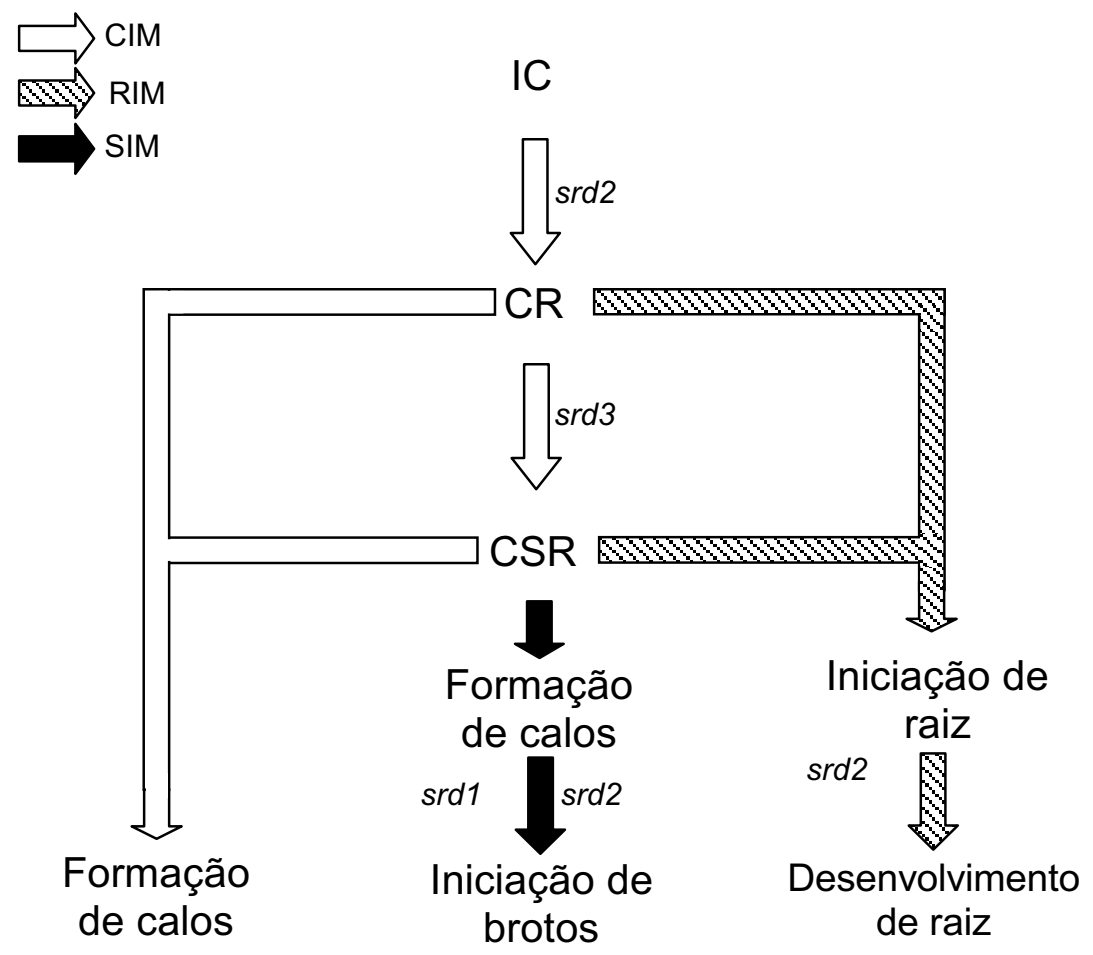

Figura 1 - Esquema hipotético de organogênese in vitro de Arabidopsis. * Fonte: Sugiyama (2000).

*IC: não competente para a organogênese e proliferação celular; CR: competência para rizogênese e proliferação celular; CSR: competência para brotação e rizogênese; CIM: meio de indução de calos; RIM: meio de indução de raízes; SIM: meio de indução de brotos. 


\subsubsection{Cultura de tecidos do gênero Passiflora}

Como visto, os principais elementos que controlam a morfogênese in vitro são os fitorreguladores, particularmente a organogênese in vitro de maracujazeiro é dependente de citocinina, principalmente da benzilaminopurina (BA).

A organogênese tem sido relatada para várias espécies de Passiflora, como $P$. amethystina, $P$. edulis $f$. flavicarpa, $P$. giberti, $P$. incarnata, $P$. maliformis, $P$. mollissima, $P$. nitida, $P$. quadrangularis e $P$. suberosa. Os efeitos de diferentes fontes de explante, reguladores de crescimento, concentração de água de coco e também radiação luminosa foram avaliadas, principalmente para $P$. edulis f. flavicarpa.

Tecidos cotiledonares, hipocotiledonares, e foliares têm sido usados como explantes para iniciar a formação de brotos em meio basal MS (Murashige \& Skoog, 1962) suplementado com BA. A organogênese pode ocorrer de calos (Mourad-Agha \& Dexheimer, 1979; Scorza \& Janick, 1980; Kantharajah \& Dodd, 1990; Monteiro et al., 2000a), como diretamente do explante (Kawata et al., 1995; Faria \& Segura, 1997; Appezzato-da-Gloria et al., 1999; Passos, 1999; Hall et al., 2000; Otahola, 2000). Culturas obtidas de segmentos entrenodais (Moran Robles, 1978, 1979; Biasi et al., 2000; Reis, 2001) mostram o mesmo padrão in vitro, com proliferação e gemas adventícias ocorrendo simultaneamente. Biasi et al. (2000) relataram que o desenvolvimento de gemas de maracujazeiro na superfície do explante é assincrônico e contínuo, e também que a citocinina residual pode promover grande número de gemas por explante, no entanto, desfavorece a elongação.

Dornelas \& Vieira (1994) reportaram que $1,0 \mathrm{mg} / \mathrm{L}$ de NAA inibiu a regeneração de brotos, com suplemento de $4,0 \mathrm{mg} / \mathrm{L}$ de BA. A condição ideal de regeneração de brotos foi observada em explantes de cotilédone, de folha e de hipocótilo cultivados sob $23 \mu \mathrm{mol} . \mathrm{m}^{-2} . \mathrm{s}^{-1}$ de radiação luminosa em meio de 
cultura contento no mínimo $1,0 \mathrm{mg} / \mathrm{L}$ de BA. No escuro, culturas de cotilédone também mostraram brotos em meio suplementado com $B A$, enquanto a rizogênese ocorreu na presença de 1,0 mg/L de NAA. Moran Robles (1978), Scorza \& Janick (1980) e Kantharajah \& Dodd (1990) relataram a influência de radiação luminosa no potencial morfogênico de explantes de Passiflora.

Monteiro et al. (2000a) reportaram a formação de calo induzida por BA em discos foliares de $P$. suberosa, mas enfatizou que organogênese ocorre somente após a transferência para o meio MSM suplementado com $\mathrm{GA}_{3}$. Este meio foi adaptado para cultivo in vitro de maracujazeiro amarelo. As mais importantes diferenças entre o meio MS e MSM são: uma aumento na concentração de $\mathrm{P}, \mathrm{Ca}$ (nitrato de $\mathrm{Ca}$ ), $\mathrm{Mg}, \mathrm{S}, \mathrm{Fe}, \mathrm{Mn}, \mathrm{Cu}, \mathrm{Na}$ e EDTA, um decréscimo na concentração de $\mathrm{Zn}$, e eliminação de $\mathrm{Cl}$ e I (Monteiro et al., 2000b).

Água de coco no meio de cultura causa um aumento na proliferação celular em P. quadrangularis (Mourad-Agha \& Dexheimer, 1979) e na formação de gemas adventícias em $P$. edulis Sims (Kantharajah \& Dodd, 1990) e em híbridos de $P$. edulis x $P$. edulis var. flavicarpa (Hall et al., 2000). Meio MS suplementado com 2,0 mg/L de BA e 10\% (v/v) de água de coco levou à maior regeneração de brotos após 56 dias de cultura (Dornelas \& Vieira, 1994).

A resposta morfogênica de cultura de Passiflora pode ser avaliada pelo número de brotos produzidos por explante e também pelo aumento na massa. Em geral, explantes responsivos desenvolvem-se muito bem e produzem um grande número de gemas adventícias.

Faria \& Segura (1997) investigaram o efeito de tiosulfato de prata (STS) na morfogênese e observaram que este significantemente aumentou a diferenciação e o desenvolvimento de gemas adventícias em explantes de hipocótilo e de follha de maracujazeiro. O uso de $8,8 \mu \mathrm{M}$ de STS favoreceu a formação de gemas adventícias como resultado da redução de etileno. Reis (2001) não observou melhora na resposta organogênica quando o STS foi utilizado. No entanto, uma influência foi observada utilizando-se o indutor de 
etileno ACC (ácido 1-amino-ciclopropano-1-carboxílico) em vários aspectos do desenvolvimento das culturas, com intensa calose e senescência dos explantes, confirmando o marcante efeito inibitório causado pelo etileno na morfogênese in vitro de maracujazeiro descrito por Barbosa et al. (2001).

De acordo com Dornelas \& Vieira (1994), no mínimo a metade das culturas de Passiflora derivadas de cotilédones formam brotos em meio MS contendo $2 \mathrm{mg} / \mathrm{L}$ de BA e $10 \%$ de água de coco. A porcentagem dos explantes que produziram brotos foram $56 \mathrm{em} P$. giberti, $70 \mathrm{em} P$. amethystina e $P$. mollissima, 90 em $P$. maliformis e 96 em $P$. edulis f. flavicarpa. O número médio de brotos por explante foi de 57,3, 18,2 e 46,0, provenientes de cotilédone, hipocótilo e folha, respectivamente para $P$. edulis f. flavicarpa. Previamente, Moran Robles $(1978,1979)$ observou o mesmo padrão de resposta em $P$. mollissima para produção de brotos oriundos de cotilédones. A porcentagem de brotos regenerados de $P$. edulis f. flavicarpa é sempre alta e sem formação de calo. Brotos de $1 \mathrm{~cm}$ são excisados e transferidos para meio $1 / 2 \mathrm{MS}$ para a sua elongação e enraizamento. Seguindo procedimentos convencionais para aclimatação, observa-se diferença na sobreviência em casa de vegetação dependendo da presença ou não de folhas nos regenerantes.

Passos (1999) observou organogênese direta a partir de discos foliares de $P$. nitida em meio contendo 0,5 ou $1,0 \mathrm{mg} / \mathrm{L}$ de $B A$, na ausência de água de coco. A recuperação de plântulas derivadas de gemas adventícias foi verificada 2 semanas após o primeiro subcultivo. Quando transferidos para o meio sem regulador, $40 \%$ das plantas enraizaram.

Organogênse direta a partir de discos foliares de $P$. edulis f. flavicarpa também foi relatada por Otahola (2000), utilizando baixas concentrações de BA (0; 0,3; 0,6; 0,9 e 1,2 mg/L). A melhor resposta foi observada após 35 dias em meio suplementado com $0,6 \mathrm{mg} / \mathrm{L}$ de BA, com $44 \%$ dos explantes com brotos. $O$ autor ressaltou a importância da presença de nervura central nos explantes e relata indução de calos proporcionada por BA, semelhantemente ao observado para $P$. suberosa (Monteiro et al., 2000a) . 
A via morfogênica direta relatada por Dornelas \& Vieira (1994) para as 5 espécies de Passiflora estudadas foi confirmada por estudos anatômicos (Appezzato-da-Gloria et al., 1999). Os explantes de disco foliar apresentaram alterações na região das bordas, após 7 dias de cultura. 0 mesofilo mostrou pequenas células com o citoplasma denso e núcleos conspícuos, associadas ou não à vascularização do explante. Aos 14 dias, observou-se o aparecimento de áreas meristemáticas, assim como divisões celulares em vários planos do parênquima fundamental na superfície adaxial da nervura central, principalmente nas camadas subepidérmicas que levou à formação de estruturas meristemáticas similares àquelas do mesofilo. $O$ desenvolvimento dessas estruturas se estendeu e a presença de vários brotos em diferentes fases de desenvolvimento foram observados aos 28 dias.

Muitos estudos reforçam a idéia de que a formação das gemas caulinares tende a ocorrer nas camadas superficiais do tecido do calo se a via for indireta, ou do tecido do explante, se a via for direta (Appezzato-da-Gloria, 1998). Desse modo, a utilização de técnica de transformação genética é bastante favorável para culturas que regeneram por via organogênica, por dois motivos. Primeiramente, pode-se adotar tanto métodos diretos (biobalística) como indiretos (Agrobacterium tumefaciens) de transformação, com alta possibilidade do gene ser integrado, uma vez que os meristemóides são formados superficialmente. A bactéria não consegue, por si só, alcançar regiões profundas do tecido. Outro aspecto diz respeito à variação somaclonal, que é evitada, principalmente quando a via organogênica é direta, sem fase de calo.

\subsection{Marcadores seletivos em transformação de plantas}

Outro requisito essencial em trabalhos de transformação de plantas é o estabelecimento do agente seletivo adequado (Tabela 1) e a determinação da sua concentração na qual a célula transformada será selecionada. A combinação do agente e sua concentração devem permitir somente o 
crescimento de células/tecidos transformados e evitar o escape dos não transformados. Por outro lado, a dosagem não pode ser excessiva a ponto de evitar também o crescimento dos explantes transformados.

Os agentes utilizados na seleção atuam diferentemente por detoxificação, modificação da enzima alvo ou decompondo substratos usados como fontes de carbono (Tabela 1).

Os genes de resistência a antibióticos de origem bacteriana, quando expressos sob promotores de plantas, têm sido efetivos em plantas. Os representantes da principal classe de antibióticos, os aminoglicosídeos, são amplamente utilizados em transformação de plantas. O mais conhecido dos antibióticos aminoglicosídeos é a canamicina, que é largamente aplicada como agente seletivo em experimentos de transformação. Outros agentes são gentamicina, geneticina, neomicina, paromomicina e higromicina (Wilmink \& Dons, 1993).

Todos os antibióticos aminoglicosídeos inibem a síntese de proteínas em células procariontes (Tabela 1). Canamicina, gentamicina e seu derivado geneticina, neomicina e paromomicina ligam-se à subunidade ribossomal 30S, inibindo a iniciação da tradução, e conseqüentemente a síntese de proteínas. A higromicina ocupa o sítio de ligação ribossomal do fator de elongação EF-2, inibindo a elongação da cadeia peptídica (Kors, 1991). Os ribossomos de mitocôndrias e cloroplastos de plantas superiores são similares aos de bactéria, e portanto são suscetíveis a antibióticos. O efeito mais drástico observado em plantas é a clorose, branqueamento das folhas causada por perda da síntese de clorofila.

Resistência à canamicina, geneticina, neomicina e paromomicina é obtida pela expressão do gene aphA2 de Tn5 de Escherichia coli (Bevan et al., 1983). Este gene codifica para a enzima APH(3')II (aminoglicosídeo 3'fosfotransferase II), também chamada NPTII (neomicina fosfotransferase II), que fosforila um grupo hidroxil específico destes antibióticos. Devido a esta fosforilação, a ligação do antibiótico ao ribossomo é inibida. A canamicina pode 
também ser detoxificada por $\mathrm{AAC}\left(3^{\prime}\right)$ (geneticina 3-N-acetiltransferase) que acetila o grupamento amino 3 ' do anel II.

Gentamicina pode também ser detoxificada por AAC (3'). Este antibiótico não contém um grupo hidroxil na posição 3' do anel I, não podendo ser fosforilada por $\mathrm{APH}\left(3^{\prime}\right)$. Porém, um derivado de gentamicina, G418, contém um grupo hidroxil extra na posição 4' do anel I, que possibilita a fosforilação por NPTII (Wilmink \& Dons, 1993). Genes que codificam a enzima ACC(3') têm sido utilizados na transformação de Petunia hybrida, Arabidopsis thaliana (Hayford et al., 1988) e tabaco (Carrer et al., 1991).

Higromicina pode ser inativada por fosforilação de um grupo hidroxil por enzima $\mathrm{APH}\left(4^{\prime}\right)$, também chamada HPT (higromicina fosfotransferase). $\mathrm{O}$ gene $h p t=a p h / V$ que codifica para esta enzima foi também isolado de $E$. coli e adequadamente empregado para expressão em células vegetais (van den Elzen et al., 1985; Waldron et al., 1985).

A resistência de células vegetais a antibióticos aminoglicosídeos é obtida por introdução de um gene que codifica uma enzima detoxificante no genoma da planta. Esta enzima detoxifica o agente seletivo e permite o crescimento de células transformadas, enquanto as células não transformadas são incapazes de crescer. Um dos principais problemas quando da utilização de antibióticos aminoglicosídeos é a "proteção" das células próximas aos tecidos não transformados, causada pelas células transformadas, chamada de "proteção cruzada" (Christou et al., 1991; Escandón \& Hahne, 1991). Por detoxificação, a concentração efetiva do antibiótico na vizinhança das células transformadas é menor. Tal "proteção cruzada" permite a regeneração de células não transformadas, levando a escapes.

Geralmente, a canamicina é adicionada em meio de crescimento em uma concentração previamente estabelecida para inibir a regeneração de células não transformadas. Pouco é conhecido sobre o transporte de canamicina pelos tecidos de planta: o antibiótico não parece se mover internamente pelo tecido, mas difundir-se através do espaço intercelular. Tem 
sido observado que esta difusão ocorre por pequenas distâncias (Weide et al., 1989), o que significa que em explantes grandes o antibiótico não invade todas as partes. É sabido que quanto menor o tamanho do explante mais eficiente é a seleção (Wilmink \& Dons, 1993).

A canamicina é pH dependente. Caso o meio esteja abaixo de 6,0, a ligação do antibiótico à membrana celular é fortemente inibida (estudos em procariontes). Além do mais, íons bivalentes $\left(\mathrm{Ca}^{2+} \mathrm{e} \mathrm{Mg}^{2+}\right)$ competem com a canamicina pelo sítio de ligação no carreador (Nap et al., 1992). Adicionalmente, outros componentes do meio de cultura podem influenciar na eficácia de canamicina: por exemplo, se o agente solidificante gelrite é usado ao invés de agar, a concentração de canamicina deve ser aumentada porque a canamicina parece se ligar ao gelrite (Wilmink \& Dons, 1993). Observações similares foram registradas com danagel e phytagel em tulipa, gladíolo e tabaco, sendo que o valor da interação 'canamicina $x$ danagel' foi muito mais significativa para atribuir grande parte da resistência à essa interação (Chauvin et al., 1999). Estes aspectos devem ser levados em consideração quando a canamicina é aplicada em cultura de tecidos.

A canamicina é muito eficaz na seleção de transformantes em dicotiledôneas comparativamente à sua ação em monocotiledôneas (Potrykus et al., 1985; Hauptmann et al., 1988; Dekeyser et al., 1989; Peng et al., 1992).

Em tulipa, por exemplo, foi observada a formação de brotos adventícios em explantes excisados de pedúnculo de flor, na presença de 500 $\mathrm{mg} / \mathrm{L}$ de canamicina. Nesta concentração, o crescimento de células não transformadas de plantas dicotiledôneas tais como petunia, tabaco (Fraley et al., 1983), e soja (Christou et al., 1988) é totalmente inibido.

Em adição aos antibióticos, os herbicidas estão sendo utilizados muito freqüentemente e com sucesso. Os genes de resistência originam-se de vários organismos, incluindo bactérias e plantas. Os mecanismos pelos quais estes genes atuam foram revisados por Comai \& Stalker (1986). 
A L-phosphinothricin (PPT), também conhecida como glufosinato, é um análogo de glutamato e atua como um inibidor competitivo da enzima glutamina sintetase (GS). Esta enzima está envolvida na assimilação de amônia e tem uma função chave na regulação do metabolismo de nitrogênio (De Block et al., 1987). A inibição da enzima causa acúmulo de $\mathrm{NH}_{4}+$ na célula. Este acúmulo, mais do que a falta de glutamina causa a morte das células (Tachibana et al., 1986a e b). A PPT é sintetizada quimicamente (Basta; Hoechst $A G$ ) ou por fermentação de Streptomyces hygroscopicus (Herbiace, produzido por Meiji Seika Ltd.). Este último, também chamado de Bialaphos, é um composto tri-peptídeo que consiste de PPT e dois resíduos alanina que são removidos da célula da planta por peptidases (De Block et al., 1987).

A resistência a herbicidas é conferida por fosfinotricina-Nacetiltransferase (PAT), que inativa PPT por acetilação, usando acetil coenzima A como cofator. Dois genes similares codificam para PAT: bar, isolado de Streptomyces hygroscopicus (Murakami et al., 1986; Thompson et al., 1987), assim chamado por causa da resistência conferida por Basta, e pat isolado de S. viridochromogenes (Wohlleben et al., 1988).

No campo, o Basta é usado para o controle de ervas daninhas. É um herbicida metabolizável, menos prejudicial para o ambiente do que outros herbicidas. Em estudos de transformação, o Basta ou PPT tem sido utilizado para selecionar plantas resistentes, pulverizando-se PPT nas plantas adultas ou adicionando-se em meio seletivo nos estádios iniciais. Um ou $3 \mathrm{mg} / \mathrm{L}$ de PPT são suficientes para selecionar células transformadas (De Block et al., 1987; Gordon-Kamm et al., 1990). Dekeyser et al. (1989) encontraram uma concentração ótima (10 mg/L) para discriminar calos de arroz transformados dos não transformados. Para uma seleção efetiva, foi importante retirar aminoácidos do meio seletivo, porque vários deles (ácido glutâmico, prolina, arginina) permitem o crescimento de células não transformadas na presença de PPT. Wright et al. (2001) não usaram os aminoácidos prolina e ácido casamino no meio de seleção com Basta. Como agente seletivo, o uso de PPT tem sido 
bem sucedido em muitas plantas (Brassica napus, Helianthus annus, milho, aveia e arroz) (Wilmink \& Dons, 1993). Em contraste com aminoglicosídeos, PPT parece se mover por vasos condutores, xilema e floema (Shelp et al., 1992).

Outras estratégias de seleção utilizam da auxotrofia dos explantes vegetais para várias substâncias, ou seja, os explantes são incapazes de regenerar e crescer na ausência de algum suplemento externo adicionado ao meio de cultura. A seleção se dá pelo fato das células transformadas serem complementadas com um gene que as tornam capacitadas a produzir uma substância essencial, a qual não está presente no meio de cultura (Joersbo, 2001).

O gene ipt de Agrobacterium tumefaciens, o qual codifica uma enzima da via de biossíntese de citocinina (isopentenil transferase) foi introduzido em tabaco. As células transformadas com esse gene produziram citocinina continuamente, e as plantas transgênicas foram regeneradas por organogênese e identificadas por mudança na sua morfologia. Esse sistema, em comparação com o uso simples do antibiótico canamicina, mostrou ser mais eficiente na recuperação das plantas transgênicas de tabaco (2,7 vezes), e eliminação de células não transgênicas (Endo et al., 2001).

Outra substância utilizada é a manose. Sabe-se que a manose é tóxica em meio de cultura. Esta é convertida em manose-6-fosfato, que não é metabolizada e se acumula em níveis inibitórios para a planta. Um gene ( $p m i)$, que codifica manose-6-fosfato isomerase, é usado como seletivo, a enzima converte a manose-6-fosfato em frutose-6-fosfato que é facilmente metabolizada através da glicólise. Como resultado, células transformadas com o gene de manose-6-fosfato isomerase tem adquirido uma vantagem metabólica comparativamente com células não transgênicas que permanecem incapazes de metabolizar a manose-6-fosfato. Este sistema funciona muito bem em beterraba, batata, trigo, milho, mandioca e mostra uma freqüência de 
transformação 10 vezes maior, comparada à seleção em canamicina (Joersbo, 2001).

Como a manose, a xilose é um carboidrato que muitas espécies vegetais não são capazes de metabolizar. A xilose isomerase converte xilose para xilulose, que é metabolizada através da via da pentose fosfato. A transformação de planta com gene $x y l A$, que codifica xilose isomerase, e subseqüente seleção em meio contendo xilose leva à obtenção de brotos transgênicos. Este sistema tem sido utilizado para tabaco, batata e tomate, com freqüência aumentada em relação à seleção simples em canamicina.

As enzimas envolvidas em metabolismos intermediários, entre elas isopentenil transferase, manose-6-fosfato isomerase e xilose isomerase, podem ser utilizadas como marcadores seletivos no processo de transformação, substituindo os sistemas tradicionais de seleção. Esses marcadores, além de aumentar a freqüência de transformação quando comparada à seleção em canamicina ou herbicida, são uma alternativa importante pois evitam a utilização de genes de resistência a antibiótico ou a herbicida, os quais têm sido alvo de críticas pelos especialistas em biossegurança devido a problemas que podem causar nos ambientes onde se cultivam plantas transgênicas (Joersbo, 2001; Reed et al., 2001; Haldrup et al., 2001). 
Tabela 1. Sumário dos efeitos de vários agentes seletivos e os genes de resistência correspondentes*.

\begin{tabular}{|c|c|c|c|c|}
\hline Agente seletivo & Efeito & $\begin{array}{l}\text { Genes de } \\
\text { resistência }\end{array}$ & Enzima & $\begin{array}{l}\text { Mecanismo de } \\
\text { resistência }\end{array}$ \\
\hline \multicolumn{5}{|l|}{ ANTIBIÓTICOS } \\
\hline \multicolumn{5}{|l|}{ AMINOGLICOSÍDEOS } \\
\hline Canamicina & $\begin{array}{l}\text { Inibição da síntese } \\
\text { de proteínas }\end{array}$ & aphA2 & $\mathrm{APH}\left(3^{\prime}\right) \mathrm{II}$ (NPTII) & Fosforilação \\
\hline $\begin{array}{c}\text { G418 } \\
\text { (Geneticina) }\end{array}$ & $\begin{array}{c}\text { Inibição da síntese } \\
\text { de proteínas }\end{array}$ & aphA2 & APH(3')II (NPTII) & Fosforilação \\
\hline Higromicina & $\begin{array}{l}\text { Inibição da síntese } \\
\text { de proteínas }\end{array}$ & $h p t=a p h I V$ & $\mathrm{APH}\left(4^{\prime}\right)$ & Fosforilação \\
\hline Bleomicina & Lesão no DNA & - & - & - \\
\hline \multicolumn{5}{|l|}{ HERBICIDAS } \\
\hline Basta, PPT & $\begin{array}{l}\text { Inibição da síntese } \\
\text { de aminoácidos }\end{array}$ & bar, pat & PAT & Acetilação \\
\hline Roundup, Glifosato & $\begin{array}{l}\text { Inibição da síntese } \\
\text { de aminoácidos }\end{array}$ & aroA, Epsps & EPSPS & $\begin{array}{c}\text { Modificação ou } \\
\text { amplificação da } \\
\text { enzima alvo }\end{array}$ \\
\hline Sulfonilrureas & $\begin{array}{l}\text { Inibição da síntese } \\
\text { de aminoácidos }\end{array}$ & $\operatorname{csr} 1-1$ & ALS & $\begin{array}{c}\text { Modificação da } \\
\text { enzima alvo }\end{array}$ \\
\hline Bromoxinil & $\begin{array}{l}\text { Inibição da } \\
\text { fotossíntese }\end{array}$ & $b x n$ & Nitrilase & $\begin{array}{l}\text { Degradação do } \\
\text { agente seletivo }\end{array}$ \\
\hline Atrazina & $\begin{array}{l}\text { Inibição da } \\
\text { fotossíntese }\end{array}$ & $p s b A$ & $\mathrm{Q}_{\mathrm{B}}$ & $\begin{array}{c}\text { Modificação da } \\
\text { enzima alvo }\end{array}$ \\
\hline \multicolumn{5}{|c|}{ OUTROS AGENTES } \\
\hline Methotrexato & $\begin{array}{l}\text { Inibição da síntese } \\
\text { de nucleotídeos }\end{array}$ & $d h f r$ & DHFR & $\begin{array}{c}\text { Modificação da } \\
\text { enzima alvo }\end{array}$ \\
\hline $\begin{array}{c}\text { Meio sem citocinina } \\
\text { exógena }\end{array}$ & $\begin{array}{l}\text { Produção } \\
\text { constante de } \\
\text { citocinina }\end{array}$ & ipt & Isopentenil transferase & $\begin{array}{c}\text { Indução da } \\
\text { organogênese }\end{array}$ \\
\hline Manose & $\begin{array}{l}\text { Inibição da } \\
\text { respiração }\end{array}$ & pmi & $\begin{array}{l}\text { Fosfomanose } \\
\text { isomerase }\end{array}$ & $\begin{array}{c}\text { Detoxificação da } \\
\text { manose }\end{array}$ \\
\hline Xilose & $\begin{array}{l}\text { Inibição da } \\
\text { respiração }\end{array}$ & xylA & Xilose isomerase & $\begin{array}{c}\text { Detoxificação da } \\
\text { xilose }\end{array}$ \\
\hline
\end{tabular}

*Adaptado de Wilmink \& Dons, 1993. 


\subsection{Transformação genética de plantas por bombardeamento de partículas (biobalística)}

A tecnologia de engenharia genética é uma alternativa para o melhoramento de plantas pelo potencial de transferência de uma característica específica a genótipos elites, sem afetar seu "background". A introdução de genes em plantas por métodos diretos e indiretos vem sendo realizadas com sucesso (ver revisões de Quecini \& Vieira, 2001; Silva Filho \& Falco, 2001).

Dunwell (2000) faz uma revisão do crescente uso comercial de culturas transgênicas. A primeira planta transgênica comercialmente produzida foi o tomate "Flavr Savr" em 1996, modificado para reduzir níveis da enzima poligalacturonase, aumentando o "tempo de prateleira". Desde então, registrase uma massiva expansão de culturas transgênicas no campo, particularmente milho, soja, canola e algodão. Atualmente, na América do Norte, as variedades transgênicas dessas culturas representam a maior parte da área plantada. Os principais genes introduzidos são de resistência a herbicida e a insetos, características que promovem um benefício econômico significativo para o agricultor (Tabela 2).

O mais completo banco de dados relacionado ao crescimento das culturas transgênicas é o órgão americano APHIS (Animal and Plant Health Inspection Service) e pode ser acessado pelo endereço: http://www.aphis.usda.gov/bbep/bp/database.html. Versões resumidas e informações gerais podem ser consultados pelos endereços: http://www.nbiap.vt.edu/cfdocs/fieldtests1.cfm. e http://www.isaaa.cornell.edu., respectivamente. 
Tabela 2. Principais culturas transgênicas e os genes introduzidos.

\begin{tabular}{|c|c|c|c|}
\hline Cultura & $\begin{array}{l}\text { Genes } \\
\text { introduzidos }\end{array}$ & $\begin{array}{l}\text { Característica de } \\
\text { resistência }\end{array}$ & Referência \\
\hline \multirow[t]{2}{*}{ milho } & $\operatorname{crylA}(\mathrm{b})$ & a insetos & Koziel et al. (1993) \\
\hline & bar & a herbicida & Armstrong (1999) \\
\hline \multirow[t]{3}{*}{ arroz } & $\operatorname{cry} \mid A(b)$ & a a insetos & Fugimoto et al. (1993) \\
\hline & $\operatorname{cry} \mid A(b)$ e $(c)$ & a insetos & Ahmad et al. (2002) \\
\hline & bar & a herbicida & Giri \& Laxmi (2000) \\
\hline \multirow[t]{3}{*}{ soja } & $\operatorname{crylA}(\mathrm{c})$ & a insetos & Stewart et al. (1996) \\
\hline & $g f-2.8$ & a fungo & Donaldson et al (2001) \\
\hline & EPSPS & a herbicida & Delannay et al. (1995) \\
\hline \multirow[t]{3}{*}{ Cana } & bar & a herbicida & Falco et al. (2000)/ \\
\hline & & & Butterfield et al. (2002) \\
\hline & hut & a insetos & Butterfield et al. (2002) \\
\hline \multirow[t]{3}{*}{ algodão } & EPSPS & a herbicida & Blair-Kerth et al. (2001) \\
\hline & $\operatorname{cryl} A(b)$ e $(c)$ & a insetos & Perlak et al. (1990)/ \\
\hline & & & Xia \& Guo (2001) \\
\hline canola & $\operatorname{crylA}(\mathrm{c})$ & a insetos & Stewart et al. (1996) \\
\hline trigo & chil1 & à doença & Chen et al. (1998a) \\
\hline tomate & $\operatorname{cry} \mid A(b)$ & a insetos & Fischoff et al. (1987) \\
\hline \multirow[t]{2}{*}{ batata } & $\operatorname{cry} I A(b)$ & a insetos & Peferoen (1992) \\
\hline & cryllIA & a insetos & Adang et al. (1993) \\
\hline
\end{tabular}

A chamada biolística ou biobalística consiste no bombardeamento de micropartículas recobertas por DNA aceleradas a velocidades supersônicas 
( $\pm 1500 \mathrm{~km} / \mathrm{h}$ ) em direção a um tecido-alvo, de modo que a velocidade destas partículas faça com que elas penetrem no tecido e promovam uma integração estável do DNA (Christou, 1990).

As micropartículas, geralmente de tungstênio ou ouro, cobertas com DNA, são introduzidas na célula alvo por aceleração. A aceleração pode ser provida por explosão química, pressão de gases, tais como Hélio ou $\mathrm{CO}_{2}$, ou por uma explosão elétrica. Nesses sistemas, a aceleração é proveniente da onda de choque gerada pela ruptura de uma membrana e não pelo impacto direto do gás ou da força elétrica sobre a membrana macrocarreadora. Os equipamentos mais eficientes e seguros para essa aceleração são os que utilizam gás Hélio a alta pressão (Klein et al., 1987) ou elétricos (Christou et al., 1988).

O sistema empregando gás Hélio sob alta pressão apresenta como vantagens: i) segurança, uma vez que a pressão de saída do gás pode ser facilmente controlada; ii) limpeza, pois os equipamentos que empregam pólvora geram gases tóxicos e produzem debris dentro do aparato; iii) menor dano ao tecido, devido à natureza praticamente inerte deste gás; iv) maior facilidade na obtenção de velocidades supersônicas, pois o baixo peso molecular do Hélio faz com que seja um gás de fácil e rápida compressão; v) campo de transformação maior e mais uniforme, devido à capacidade de se induzir velocidades maiores por toda a área-alvo combinada com uma melhor dispersão de partículas (Sanford, 1990).

Segundo Potrykus (1990) as principais vantagens da biobalística são: (a) a facilidade de manuseio, (b) o fato de um tiro ter capacidade de atingir muitas células, (c) a universalidade do tecido-alvo e (d) a capacidade das partículas atingirem até as camadas mais profundas de células. É importante ressaltar que pelo fato deste método permitir a utilização de diferentes tecidos o seu sucesso depende estritamente da habilidade das células do tecido alvo em proliferar e dar origem a uma planta fértil. 
As principais espécies vegetais de importância agronômica que tiveram genes introduzidos por engenharia genética, usando a biobalístia são: milho, arroz, trigo, cana-de-acúcar, batata, abacaxi, banana, etc.

A biobalística também permite a introdução de vários genes em uma mesma planta (piramidamento), utilizando-se apenas um marcador seletivo (Bogorad, 2000; Daniell, 1999; Pink \& Puddephat, 1999). Chen e colaboradores (1998b) co-bombardearam arroz com 13 genes, usando resistência à higromicina como agente seletivo para todas as características introduzidas. Plantas contendo de 1 a 13 genes foram selecionadas.

No entanto, as taxas de expressão estável dos transgenes introduzidos por biobalística são relativamente baixas, apesar da alta freqüência de expressão transiente. Além do mais, geralmente, ocorrem inserções múltiplas do transgene o que pode resultar em silenciamento ou instabilidade do transgene (Lessard et al., 2002).

$\mathrm{Na}$ verdade, pouco é conhecido sobre como os transgenes se integram fisicamente no genoma vegetal. Os 2 métodos de transformação mais utilizados (Agrobacterium e biobalística) têm gerado plantas com integração de múltiplas e rearranjadas cópias do transgene em um único loco físico. As múltiplas cópias do transgene podem ser rearranjadas de conformação cabeça com cabeça, cabeça com cauda, truncada, ou espaçada com outras seqüências de DNA (Takano et al., 1997; Kohli et al., 1998, 1999; Pawlowski \& Somers, 1998; Jackson et al., 2001).

Há duas hipóteses para explicar possíveis mecanismos de integração de genes inseridos por biobalística: na forquilha de replicação, que resulta em cópias espaçadas (Pawlowski \& Somers, 1998), ou a multimerização dos transgenes, ou seja, a ligação de vários transgenes na célula vegetal, antes da integração no genoma hospedeiro (Kohli et al., 1998).

Jackson et al. (2001) estudaram a integração dos transgenes de 13 transformantes independentes de trigo, obtidos por biobalística, por análise de "FISH", "fiber-FISH", e hibridização após "Southern", e obtiveram resultados que 
suportam as hipóteses supracitadas. Nesse trabalho, 12 linhagens transgênicas foram transformadas com um único plasmídeo e uma linhagem foi cotransformada com 2 plasmídeos, os quais co-segregaram geneticamente. Três padrões de integração foram observados com o experimento de "fiber-FISH": Tipo I, integração de segmento grande, repetido em tandem; Tipo II, grandes inserções repetidas em tandem, espaçadaças por seqüências de DNA; e Tipo III, pequenas inserções, possivelmente espaçadas com DNA desconhecido. O "fiber-FISH" também confirmou o estudo de "Southern blot", o qual estimou o número de cópias do transgene variando de 6 a 17. O estudo pela técnica de "FISH" em cromossomos metafásicos possibilitou localizar a integração dos transgenes em regiões tanto de hetero como de eucromatina, como também identificou que a integração ocorreu em regiões proximal, intersticial e distal dos cromossomos.

Recentemente, espécies como a batata (Romano et al., 2001) e abacaxi (Sripaoraya et al., 2001) foram transformadas por bombardeamento de partículas. Freqüências de transformação de $20 \%$ em batata foram superiores ao obtido por Agrobacterium (14\%). A freqüência de transformação em abacaxi, variedade "Phuket", não foi tão elevada $(2,67 \%)$, no entanto, foi o primeiro registro da introdução de um gene de importância agronômica (bar), o qual confere aos transgênicos tolerância ao herbicida Basta, comprovada por ensaios controlados.

Modificações em alguns dos parâmetros do protocolo de bombardeamento vêm sendo realizadas para monocotiledôneas, com a obtenção de plantas transgênicas. Quando substituiu-se o marcador seletivo herbicida (bar) por fosfomanose isomerase (pmi), enzima que quebra o açúcar manose do meio de cultura para sua utilização como fonte de carbono. Taxas de transformação de $45 \%$ e $20 \%$ foram obtidas para milho e trigo, respectivamente (Wright et al., 2001; Reed et al., 2001). 


\subsubsection{Transformação genética em espécies frutíferas}

É crescente o número de espécies frutíferas transformadas, destacando-se, Vitis vinifera e V. rupestris (Mullins et al., 1990; Perl et al., 1996), pêssego (Smigocki \& Hammerschlag, 1991), ameixa (Mante et al., 1991;

Machado et al., 1992; Scorza et al., 1994, 1998), maçã (Norelli \& Aldwinckle, 1993; Norelli et al., 1994; Ko et al., 2000), pera (Reynoird et al., 1999), Musa spp. (Sági et al., 1995a, b; May et al., 1995; Dugdale et al., 2000; Becker et al., 2000), abacaxi (Sripaoraya et al., 2001) e Citrus spp. (Peña et al., 1995 a, b; Gutierrez et al., 1997; Pérez-Molphe-Balch \& Ochoa-Alejo, 1998; Bond \& Roose, 1998; Fleming et al., 2000).

As características introduzidas são diversas, por exemplo, resistência a herbicida, a vírus e à bacteriose.

A transformação genética do maracujazeiro ( $P$. edulis f. flavicarpa), via Agrobacterium tumefaciens, foi relatada pela primeira vez por Manders et al. (1994). Esses autores obtiveram 3 plantas transformadas, mediante a utilização de uma estirpe desarmada de $A$. tumefaciens (GV3111SE) contendo o vetor cointegrado pMON200, o qual carrega o gene nptIl.

O estudo seguinte, também via $A$. tumefaciens, foi realizado por Silva (1998). Nesse trabalho, foi utilizada a estirpe LBA4404, que carrega o plasmídeo pBI121, o qual contém os genes uidA e nptll. Foram obtidas 6 plantas transgênicas com uma eficiência de tranformação de $2 \%$. Essas plantas foram caracterizadas por PCR e "Southern blot". O padrão de expressão do gene uidA, avaliado por teste histoquímico, ocorreu, predominantemente, na região de tecidos vasculares, tanto em caules quanto em folhas dos ramos transformados.

A introdução de um gene de importância agronômica foi feito por Braz (1999) que isolou e seqüenciou genes da proteína capsidial e da replicase de um Potyvirus causador do endurecimento dos frutos do maracujazeiro. Um fragmento do genoma contendo $2 / 3$ da região 3 ' do gene da replicase viral e a 
região 5' do gene da proteína capsidial foi utilizado para a transformação de explantes foliares de maracujá. Essa construção não contém um códon iniciador, de forma que a resistência deverá ser mediada pela hibridação do RNA viral com o RNA transgênico, por meio de silenciamento póstranscricional. O fragmento viral foi subclonado no vetor binário pBI121, e o plasmídeo recombinante foi inserido em Agrobacterium tumefaciens (LBA4404). As plantas selecionadas foram avaliadas por PCR para a presença do fragmento viral e também dos genes nptll e uidA. Apesar de não obter amplificação do gene de interesse, o autor concluiu que as plantas foram transformadas baseando-se na detecção dos genes uidA e nptIl.

O único trabalho de transformação em maracujazeiro pelo método de biobalística foi realizado por Otoni et al. (1996). Os plasmídeos pEA18 e pJMD67, ambos com o gene uidA, foram bombardeados em calos embriogênicos de $P$. giberti, utilizando-se partículas de ouro ou tungstênio. Uma freqüência de $45 \%$ dos explantes inoculados mostraram expressão de GUS para as duas partículas.

\subsection{Estratégias para obtenção de resistência à bacteriose através da engenharia genética e expressão de proteínas heterólogas antibacterianas}

Düring (1996) relata que são poucos os estudos de engenharia genética visando à produção de plantas com resistência a bactérias fitopatogênicas, em comparação com aqueles relativos a outros tipos de patógenos. Esse quadro tende à mudança, devido ao crescente número de trabalhos que tem sido publicados, cuja finalidade é obter resistência a bacterioses.

São vários os genes clonados e utilizados para expressão da resistência a patógenos em plantas. Entre eles: genes que codificam para proteínas líticas de insetos (cecropina, atacina, sarcotoxina); genes de lisozimas de diferentes origens; de lactoferrina; de defesa (tioninas) e de resistência 
(Xa21) oriundos da própria planta (revisão em Düring, 1996; Mourgues et al., 1998). Nesta revisão, serão abordados somente os estudos envolvendo genes pertencentes à classe das proteínas ou peptídeos originários de insetos. Estes têm sido objeto de vários estudos, pois esses peptídeos podem gerar novos fatores de resistência ou complementar o mecanismo natural de resistência existente (Düring, 1996).

As proteínas bactericidas são componentes importantes no mecanismo de defesa de muitos grupos de animais, incluindo artrópodes (particularmente insetos), anfíbios e mamíferos. Provavelmente, atuam em sinergismo com outros compostos (como tem sido mostrado em insetos) e têm ação bactericida contra uma gama de bactérias Gram negativas e positivas (Mourgues et al., 1998).

Esses peptídeos são excelentes candidatos para aumentar os mecanismos de resistência em plantas devido, principalmente, à rápida habilidade biostática contra as células alvo, à atividade em baixas concentrações e natureza não tóxica para células eucarióticas superiores (Reed et al., 1997).

Os insetos têm um sistema de resistência induzível conhecido como imunidade humoral ou "cell free", o qual é ativado nas infecções bacterianas. Quando bactérias não patogênicas estão presentes ou são inoculadas, os insetos respondem com produção de fatores com atividade bactericida (revisão de Boman \& Hultmark, 1987; Hultmark, 1993).

Embora mais de 400 diferentes peptídeos que conferem imunidade tenham sido identificados em eucariontes (Hoffmann et al., 1999), a maioria das espécies de insetos produz pouco mais de 10 classes de peptídeos. Este número relativamente pequeno deve combater um amplo espectro de patógenos. Muitas proteínas líticas bactericidas têm sido identificadas, constituindo mais de 50 fatores antibacterianos (Boman et al. 1991).

Os peptídeos produzidos na hemolinfa de Hyalophora cecropia, em resposta à infecção por bactérias, têm sido caracterizados quanto ao seu modo 
de ação (Boman \& Hultmark, 1987). A introdução de genes que codificam para proteínas antibacterianas de insetos, por engenharia genética, tem aumentado a resistência de plantas contra bactérias fitopatogênicas (Jaynes et al., 1987; Norelli et al., 1994; Mourgues et al., 1998; Reynoird et al., 1999, Mitsuhara et al., 2000). A eficiência dos transgenes para conferir resistência depende do seu nível de expressão (Florack et al., 1995), da estabilidade da proteína na planta (Okamoto et al., 1998), e da localização apropriada da proteína para exercer sua atividade (Düring, 1996). A estratégia mais investigada é a expressão da cecropina em plantas, mas ainda não se tem um resultado claro, especialmente a campo.

A cecropina é uma das principais proteínas bactericidas que têm uma ação na membrana celular bacteriana (Boman et al., 1991; Florack et al., 1995). Ela se insere na membrana das bactérias, rompendo sua estrutura. Um estudo sistemático destes efeitos (Nordeen et al., 1992) mostrou quais os níveis requeridos de cecropina $B$ para eliminar várias bactérias fitopatogênicas.

A transformação de plantas, usando o gene da cecropina ou de moléculas sintéticas da proteína, tem sido descrita (Jaynes et al., 1993; Hightower et al., 1994; Allefs et al., 1995; Florack et al., 1995, Huang et al., 1997). Huang et al. (1997) e Jaynes et al. (1993) demonstraram reduzida severidade da doença em tabaco transgênico expressando análogos da cecropina sob infecção com Pseudomonas syringae pv. tabaci e $P$. solanacearum, respectivamente. No entanto, plantas de tabaco expressando cecropina nativa não mostraram resistência a $P$. syringae pv. tabaci ou $P$. solanacearum, presumivelmente, devido à degradação do peptídeo por proteases endógenas (Florack et al., 1995; Hightower et al., 1994).

A sarcotoxina de Sarchophaga peregrina (Matsumoto et al., 1986) também pertence ao grupo dos peptídeos antibacterianos e, assim como a cecropina, interage com a membrana celular da bactéria, causando perda do potencial eletroquímico (Nakajima et al., 1987). Mitsuhara et al. (2000) relatam que a sarcotoxina IA é o melhor candidato a exercer atividade antibacteriana, já 
que a sarcotoxina IA mostrou tal atividade aumentada e em espectro mais amplo que a cecropina B (Okada \& Natori, 1984). De fato, a sarcotoxina tem exercido alta atividade antibacteriana, comparável àquela dos antibióticos (Nakajima et al., 1987).

Oshima et al. (1999) utilizaram um promotor constitutivo para expressar sarcotoxina IA em plantas transgênicas de tabaco e demostraram resistência aumentada do hospedeiro à infecção bacteriana (Erwinia carotovora subsp. carotovora e Pseudomonas syringae pv. tabaci). Recentemente, Mitsuhara et al. (2000) relataram que a sarcotoxina IA mostrou atividade antifúngica in vitro (Rhizoctonia solani e Pythium aphanidermatum) em plantas de tabaco. Também, contra bactérias nocivas ao intestino humano, tais como Escherichia coli, Clostridium ramosum e C. paraputrificum, em testes in vitro (Mitsuhara et al., 2001).

Além das cecropinas e sarcotoxinas, as atacinas são proteínas bactericidas $(20 \mathrm{kDa})$ encontradas na hemolinfa de insetos. Essa propriedade bactericida é designada pela produção de proteínas ou peptídeos que lisam ou previnem o crescimento da bactéria fitopatogênica na planta.

\subsection{Atacinas como agentes bactericidas}

A classe na qual a atacina se integra é uma das maiores de peptídeos antibacterianos (Lazzaro \& Clark, 2001). O aspecto característico dessa família de peptídeos é a conservação fraca do domínio G, rico em glicina, que está presente em uma ou mais cópias (Hultmark, 1993). Nessa família se incluem: atacinas encontradas em mariposas (Hyalophora cecropia, Drosophila melanogaster e Trichoplusia ni), sarcotoxina II de Sarcophaga peregrina e diptericina de moscas (Phormia terranovae e D. melanogaster) e, possivelmente, a coleoptericina de besouro (Zophobas atratus).

Seis atacinas foram purificadas de $H$. cecropia, sendo quatro básicas (A-D) e duas ácidas/neutras (E e F), com massa molecular de 20 a $23 \mathrm{kDa}$ 
(Hultmark et al., 1983; Sun et al., 1991). Pelos dados de seqüenciamento de aminoácidos e de cDNA, foi deduzido que 2 genes são responsáveis pela formação das seis diferentes isoproteínas (Kockum, et al., 1984, Engström et al., 1984a).

Quatro genes de atacinas (A, B, C e D) foram identificados em Drosophila melanogaster (Asling et al., 1995; Dushay et al., 2000, Hedengren et al., 2000). Os genes se encontram ligados, mostram homologia com os genes da sarcotoxina II de Sarcophaga peregrina e com o das atacinas de Hyalophora cecropia (Asling et al., 1995).

O gene atacina $A$ foi também isolado de Trichoplusia ni (Kang et al., 1996), o qual possui padrões similares ao de $H$. cecropia. Ao nível de nucleotídeo e de peptídeo, a atacina de $T$. ni mostra alta homologia com a forma acídica da atacina de $H$. cecropia, com $63 \%$ de identidade com a parte madura da proteína (Kang et al., 1996).

Os peptídeos maduros são tipicamente compostos de $\sim 190$ aminoácidos e são letais para bactérias Gram negativas. As atacinas de $H$. cecropia afetam também a taxa de crescimento de algumas bactérias Gram positivas (Hultmark et al., 1983, Engström et al., 1984b).

O principal alvo da atacina em bactérias Gram negativas é a parede celular, mais especificamente a membrana externa (Engström et al., 1984b), acarretando uma alteração nas propriedades de permeabilidade da membrana que, por sua vez, propicia o acesso de outras proteínas antibacterianas como lisozima e cecropina, as quais atuam na parede celular e membrana citoplasmática da bactéria, respectivamente, intensificando assim a resistência dos insetos às bacterias (Carlsson et al., 1991).

Mais especificamente, as atacinas ligam-se diretamente aos lipopolissacarídeos (LPS) da membrana externa, desorganizando a membrana e levando a sua permeabilização. Essa ligação também causa a inibição da síntese de várias proteínas específicas da membrana externa, provavelmente através de inibição "feedback", limitando a habilidade das bactérias de restaurar 
a função da membrana (Carlsson et al., 1991, 1998). Em concentração suficientemente alta, as atacinas podem causar lise da célula bacteriana (Engström et al., 1984b).

\subsubsection{Transformação de plantas com o gene da atacina}

Para determinar o efeito da atacina A contra a ferrugem do fogo, doença causada por Erwinia amylovora, o gene foi introduzido em macieiras utilizando vetores binários de Agrobacterium tumefaciens, sob o controle do promotor constitutivo 35S (Norelli \& Aldwinckle, 1993). Os transformantes $T_{1}$ continham o gene, conforme demonstrado por "Southern blot" seguido de hibridização molecular. Esses transformantes foram avaliados quanto à resistência inoculando-se um isolado de $E$. amylovora $\left(5 \times 10^{6} \mathrm{ufc} / \mathrm{mL}\right)$ e determinando-se a porcentagem de brotos que desenvolveram necrose. Os transformantes mostraram alto nível de resistência a $E$. amylovora.

Norelli et al. (1994) transformaram macieira com o gene atacina $E$ visando resistência ao patógeno $E$. amylovora. Dos 648 segmentos foliares inoculados com A. tumefaciens (estirpe LBA4404), 36 regenerantes foram resgatados em meio com $10 \mu \mathrm{M}$ de paromomicina. Análises moleculares confirmaram a inserção e a expressão do gene atacina $E$. A transcrição do gene exógeno pôde ser detectada, mas a tradução não foi analisada. A macieira transgênica M.26 mostrou resistência à infecção por $E$. amylovora quando comparada ao genitor doador de explante.

Plantas transgênicas de antúrio foram obtidas via $A$. tumefaciens carregando o gene atacina visando adquirir resistência a Xanthomonas campestris, causadora de ferrugem (Chen \& Kuehnle, 1996). A proteína atacina foi expressa em antúrios transgênicos, confirmada por "Western blot". No entanto, os autores discutem que a atacina pode ter somente uma atividade bactericida moderada contra $X$. campestris. 
Reynoird et al. (1999) transformaram pereiras com o gene atacina $E$ via A. tumefaciens e a sua expressão foi confirmada pelas técnicas "Northern blot" e RT-PCR (PCR usando transcriptase reversa). A presença da proteína foi detectada por "Western blot". A análise de resistência ao patógeno $E$. amylovora dos transformantes foi feita in vitro, inoculando-se a estirpe do patógeno numa concentração de $5 \times 10^{7} \mathrm{ufc} / \mathrm{mL}$. Os transformantes mostraram resistência intermediária enquanto os não transformantes foram suscetíveis.

É sabido que a introdução de uma seqüência 'leader' não traduzível, tais como a dos vírus do mosaico de alfafa e mosaico de tabaco, nos cassetes de expressão permite um aumento do conteúdo de RNAm correspondente ao gene exógeno nas plantas transformadas (Datla et al., 1993; Mitsuhara et al., 1996). Outro aspecto importante é o destino da proteína heteróloga para locais apropriados. A maioria das proteínas endógenas relacionadas à patogênese (PR), fitoalexinas ou ligninas, estão localizadas no espaço intercelular (apoplasto), onde a bactéria fitopatogênica se multiplica antes de atacar as células da planta (Alfano \& Collmer, 1996, Bogs et al., 1998).

Ko et al. (2000) construíram 3 vetores binários que estão ilustrados a sequir (Figura 2).

Os plasmídeos (p35SAtt, p35SAMVAtt e p35SAMVPAtt) e o pLDB15 contendo AttE sob o controle do promotor do inibidor de proteinase II (Pin2) foram usados em transformação de cultivares de maçã ("Galaxy" e M.26), mediada por Agrobacterium, para aumentar a resistência a $E$. amylovora. Os resultados mostraram que a quantidade da proteína atacina nas linhagens de maçã transformadas com a construção contendo a seqüência 'leader' AMV foi 3 vezes maior. As análises de "Northern blot" indicaram que essa seqüência intensifica a transcrição de RNA em maçã como detectado em outras plantas. A linhagem 'Galaxy' transformada com o gene AttE, fusionado ao peptídeo sinal (SP), mostrou menor nível da proteína atacina em comparação com aquelas que receberam o gene sem o SP. No entanto, mostraram menos sintomas da doença do que aquelas que receberam a construção sem o peptídeo de 
direcionamento. Esses dados indicam que SP é capaz de direcionar a proteína atacina para o espaço intercelular, sugerindo que a proteína secretada no apoplasto é mais efetiva na redução da infecção quando comparada à presença da proteína localizada intracelularmente.

A- p35SAtt

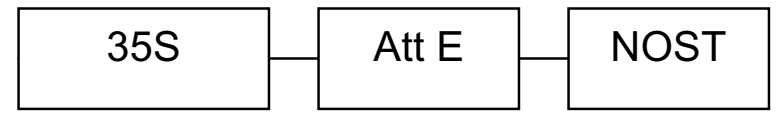

B- p35SAMVAtt

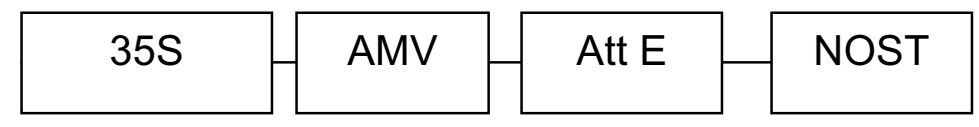

C- p35SAMVSPAtt
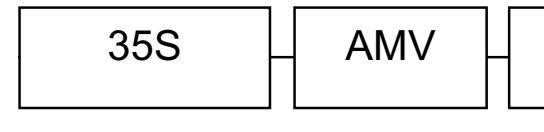

SP

Att $\mathrm{E}$

NOST

D- pLDB15

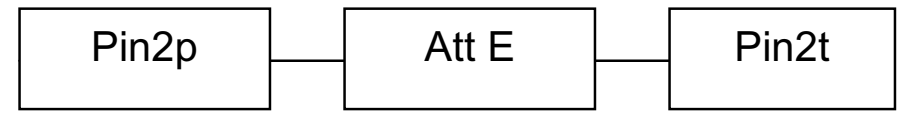

Figura 2 - Construções utilizadas para transformação de maçã ("Galaxy" e M.26) mediada por Agrobacterium tumefaciens (EHA105). *

Fonte: Ko et al. (2000)

*35S: promotor $35 \mathrm{~S}$ do vírus do mosaico da couve-flor, AttE: cDNA do gene atacina $E$ de $H$. cecropia, NOST: terminador do gene da nopalina sintase; AMV: seqüência "leader" não traduzida do vírus do mosaico da alfafa; SP: peptídeo sinal da proteína relacionada à patogênese 1b de tabaco; Pin2p e Pin2t: promotor e terminador do gene inibidor de proteinase II de batata, respectivamente. 


\section{MATERIAL E MÉTODOS}

\subsection{Material Vegetal}

As sementes de maracujá amarelo (Passiflora edulis Sims f. flavicarpa Deg.), provenientes da região de Vera Cruz, SP, foram fornecidas pelo Prof. Dr. Jorge Alberto M. Rezende (ESALQ/USP) e pela cooperativa AFRUVEC (Associação dos Fruticultores da Região de Vera Cruz).

A população Sul Brasil é um importante material pois constitui a base genética para maioria dos programas de melhoramento, principalmente no que se refere às características de tamanho de fruto. No entanto, é um material bastante susceptível à bacteriose causada por Xanthomonas campestris pv. passiflorae.

As sementes foram desinfestadas por imersão em uma solução de benomyl 1,0 g/L (p/v), "overnight" sob agitação de 130 r.p.m. Em seguida, foram esterilizadas por imersão em álcool $70 \%$ (v/v) por 40 s e em hipoclorito de sódio (NAOCl) a $2 \%(\mathrm{v} / \mathrm{v})$ contendo 2 a 3 gotas de Tween 80 , por 30 min. Lavagens sucessivas com água destilada, deioniozada e esterilizada foram realizadas antes da inoculação.

As sementes foram escarificadas com bisturi e inoculadas em tubos de cultura $(24 \times 85 \mathrm{~mm} ; 30 \mathrm{~mL}$ ) contendo $10 \mathrm{~mL}$ de meio MS (Murashige \& Skoog, 1962) com metade da sua concentração original de sais e vitaminas, acrescido de sacarose $(15 \mathrm{~g} / \mathrm{L})$ e phytagel $0,18 \%(\mathrm{p} / \mathrm{v})$. A germinação foi feita a $25 \pm 2^{\circ} \mathrm{C}$, fotoperíodo de 16 horas e intensidade luminosa de $25 \mu \mathrm{mol} \cdot \mathrm{m}^{-2} \cdot \mathrm{s}^{-1}$. 
A população inoculada in vitro foi constituída de 70 indivíduos, na tentativa de evitar excessiva perda de variabilidade genética. Essas plantas foram subcultivadas mensalmente para excisão dos explantes.

\subsection{Morfogênese in vitro}

\subsubsection{Organogênese direta}

Discos foliares de plantas de maracujá com 20 dias de cultura foram utilizados como explantes e inoculados com a superfície abaxial em contanto com o meio de cultura.

Os experimentos foram conduzidos em meio MS, em 3 recipientes, placa de Petri $(6 \times 1,3 \mathrm{~cm}, 30 \mathrm{~mL})$, frasco $(6 \times 9 \mathrm{~cm}, 200 \mathrm{~mL})$ e tubo $(2,4 \times 8,5$ $\mathrm{cm} ; 30 \mathrm{~mL}$ ). Doze combinações (tratamentos) por recipiente foram realizados: água de coco $(5 \%$ e $10 \%)$, BA $(0,5 ; 1,0$ e $2,0 \mathrm{mg} / \mathrm{L})$ e agente solidificante (Phytage $^{\mathrm{TM}} 0,18 \%$ e Agar ${ }^{\mathrm{TM}}$ 0,60\%, ambos da Sigma Chemical Company). O $\mathrm{pH}$ do meio de cultura foi ajustado para 5,8 antes da autoclavagem feita por 20 min a $121^{\circ} \mathrm{C}$. Os volumes de meio foram 12,30 e $10 \mathrm{~mL}$, respectivamente para placa, frasco e tubo. As placas foram seladas com Parafilm ${ }^{\mathrm{TM}}$, os frascos com tampas plásticas e os tubos com filme de PVP. O delineamento inteiramente casualisado, com 6 repetições foi utilizado. Cada parcela foi constituída por 3 (placa e frasco) ou 2 explantes (tubo).

As culturas foram mantidas sob luz fornecida por lâmpada branca fluorescente, radiação luminosa de $25 \mu \mathrm{mol} \cdot \mathrm{m}^{-2} \cdot \mathrm{s}^{-1}$, a $25 \pm 2^{\circ} \mathrm{C}$ e fotoperíodo de $16 \mathrm{~h}$.

Os tratamentos foram avaliados sob microscópio estereoscópico, aos 28 dias e fotografados (Fujifilm ASA100). As combinações mais eficientes foram determinadas avaliando-se a: porcentagem de explantes com resposta organogênica, porcentagem da área do explante contendo gemas, e nota (10 a 50), atribuída à qualidade dos brotos, isto é, coloração, tamanho e vigor do 
broto. Algumas amostras foram selecionadas para medir-se a quantidade de brotos formados por explante.

Os dados estatísticos foram analisados usando PROC GLM do programa SAS, Versão 6.11 (SAS Institute, Cary, NC). $P<0,05$ foi usada como referência e o teste Tukey de médias foi adotado.

\subsubsection{Organogênese indireta}

Hipocótilos e segmentos entrenodais foram excisados de plantas com 20 a 30 dias de idade, cortados transversalmente $(2 \mathrm{~mm})$ e usados como explantes. A melhor combinação selecionada conforme descrito em 3.2.1 foi utilizada: meio $\operatorname{MSB}(A)$ : sais e vitaminas de MS (Murashige \& Skoog, 1962) acrescido de água de coco $5 \%(\mathrm{v} / \mathrm{v}), 0,5 \mathrm{mg} / \mathrm{L}(\mathrm{p} / \mathrm{v})$ de BA e Agar ${ }^{\mathrm{TM}}$ 0,6\% (p/v). $\mathrm{O} \mathrm{pH}$ do meio foi ajustado a 5,8 o qual foi autoclavado a $121^{\circ} \mathrm{C}$ por $20 \mathrm{~min}$. Os experimentos foram conduzidos em placas de Petri, em delineamento experimental do tipo inteiramente casualizado, com 3 repetições. A cultura foi

mantida sob luz branca fluorescente $\left(25 \mu \mathrm{mol} . \mathrm{m}^{-2} \cdot \mathrm{s}^{-1}\right.$, a $25 \pm 2^{\circ} \mathrm{C}$ e fotoperíodo de 16 h). A avaliação foi feita sob microscópio estereoscópico a cada 3 dias.

\subsubsection{Análises histológicas das estruturas diferenciadas a partir de hipocóticos e segmentos entrenodais}

Após 18 dias de cultivo, as estruturas diferenciadas oriundas de explantes hipocotiledonares e de segmentos entrenodais foram fixadas em solução de Karnovsky (Karnovsky, 1965). As amostras foram levadas à uma bomba de vácuo para a retirada do ar dos espaços intercelulares, desidratadas em série etílica e infiltradas em resina glicol metacrilato (Reichert-Jung). As secções foram feitas em micrótomo rotatório $(5 \mu \mathrm{m})$, longitudinalmente, e as 
lâminas coradas com azul de toluidina $0,05 \%(\mathrm{p} / \mathrm{v})$, em tampão fosfato e ácido cítrico (Sakai, 1973).

\subsubsection{Análises ultra-estruturais da organogênese indireta}

Segmentos entrenodais com 18 dias de cultivo foram fixados em solução de Karnovsky, desidratados em série etílica, secos ao ponto crítico com dióxido de carbono, montados sobre suportes de alumínio e recobertos com uma camada de ouro de 30 a $40 \mathrm{~nm}$. As observações foram realizadas sob microscópio eletrônico de varredura modelo DSM $940^{\mathrm{A}}$ (Zeiss) operando a $5 \mathrm{kV}$.

\subsection{Agente seletivo}

Para o ensaio de agente seletivo foi utilizado o meio $\operatorname{MSB}(A)$. Os antibióticos e o herbicida previamente filtroesterilizados foram adicionados quando a temperatura do meio estava em torno de $45^{\circ} \mathrm{C}$. Os agentes avaliados foram: 3 antibióticos (canamicina, higromicina e geneticina - Sigma Chemical Company, USA) nas concentrações $0 ; 5 ; 10 ; 12,5 ; 15 ; 20 ; 25 ; 50 ; 75$ e 100 mg/L e 1 herbicida (fosfinotricina - Sigma Chemical Company) nas concentrações de 0,0; 2,0; 3,0; 4,0; 6,0; 8,0; 10,0 e 25,0 mg/L.

O experimento foi conduzido em placas de Petri $(9 \times 1,5 \mathrm{~cm}, 50 \mathrm{~mL})$, em delineamento inteiramente casualizado, contendo 6 repetições, sendo que a parcela consistiu de uma placa com 8 explantes.

As culturas foram mantidas no escuro por 7 dias e após esse período, transferidas para luz branca fluorescente $\left(25 \mu \mathrm{mol} \cdot \mathrm{m}^{-2} \cdot \mathrm{s}^{-1}\right)$ a $25 \pm 2^{\circ} \mathrm{C}$ e fotoperíodo de $16 \mathrm{~h}$.

As análises foram efetuadas após 7 dias para a condição no escuro e aos 28 dias no claro, sob microscópio estereoscópico e fotografados. A porcentagem média de explantes sobreviventes, e dentre os sobreviventes, os 
que apresentaram somente uma expansão do explante e/ou presença de brotos foram discriminados. Os dados coletados após 28 dias foram analisados usando o programa SAS, Versão 6.11 (SAS Institute, Cary, NC). $P<0,05$ foi usado como referência procedendo-se o teste Tukey de médias.

\subsection{Construção do vetor de expressão}

\subsubsection{Etapa 1- Construção de pFFatacina}

A etapa 1 da construção molecular foi realizada no Laboratório de Biotecnologia Vegetal do IAPAR, Londrina/PR.

$O$ gene atacina $A$ encontrava-se clonado no vetor pBlueScript, o qual foi cedido a ESALQ pelo Dr. Luiz Gonzaga Esteves Vieira do IAPAR. Antes da construção do cassete de expressão, o gene foi seqüenciado visando conhecer a sua seqüência e mapa de restrição. Em seguida, o plasmídeo foi digerido com as enzimas de restrição Sacl (extremidade 5') e Kpnl (extremidade 3'), e o fragmento de $\sim 1050 \mathrm{pb}$ correspondente ao cDNA do gene atacina $A$ foi extraído do gel de agarose $(1,0 \%)$, purificado e quantificado.

O gene atacina $A$ foi inserido dentro dos sítios correspondentes do vetor pFF19 $(4,2 \mathrm{~kb})$, o qual contém: promotor $35 \mathrm{~S}$ duplicado, sítio múltiplo de clonagem (MCS) derivado de pUC e terminador 35S (Timmermans et al., 1990).

A ligação do fragmento correspondente ao cDNA do gene atacina $A$ com o pFF19 foi feita pela ação da T4 ligase (Invitrogen ${ }^{\mathrm{TM}}$ ), conforme sugerido por Sambrook et al. (1989), numa proporção de 2:1 (inserto:vetor), em concentrações equivalentes a $90 \mathrm{ng}$ e $45 \mathrm{ng}$, respectivamente. A reação permaneceu a $20^{\circ} \mathrm{C}$ durante $2 \mathrm{~h}$.

O produto de ligação foi transferido para Escherichia coli $(\mathrm{DH} 5 \alpha)$ (Hanahan, 1983), juntamente com os controles positivo (plasmídeo pFF19 circular) e negativo (sem plasmídeo). 
A confirmação da construção do cassete de expressão foi feita por PCR, utilizando-se oligonucleotídeos iniciadores ("primers") para o gene atacina $A$ e visualização em gel de agarose $1,0 \%$ sob voltagem de $2,8 \mathrm{~V} / \mathrm{cm}$. Confirmação complementar foi realizada por enzimas de restrição, determinando-se, assim, o mapa de restrição.

O DNA plasmidial foi purificado por método de lise alcalina usando o "Plasmid Mini Kit" (Qiagen) e a quantificação foi feita por espectrofotometria e confirmada por eletroforese em géis de agarose 1,0\% (p/v) em TBE 1X. O DNA foi estocado a uma concentração de pelo menos $1 \mu \mathrm{g} / \mu \mathrm{L}$ em água mili-Q autoclavada e estocado a $-20^{\circ} \mathrm{C}$.

\subsubsection{Etapa 2- Construção de pCatacina 1300 e pCatacina 2300}

Para obtenção de um vetor contendo o gene de interesse (atacina A) e o gene de seleção em planta, foram construídos os vetores pCatacina 1300 e pCatacina 2300, os quais contêm, respectivamente, os genes de resistência aos antibióticos higromicina e canamicina.

O cassete de expressão (promotor 35S35S-atacinaA-terminador) foi liberado de pFFatacina (Etapa 1), por digestão total com a enzima HindIII, seguida por uma digestão parcial com EcoRI pelo fato de haver sítios internos desta enzima no interior do gene.

Para o teste de digestão parcial, foram utilizados os tratamentos: 6,0 $\mu \mathrm{g}$ de DNA plasmidial e concentrações de EcoRI iguais a 0,2; 0,3; 0,4; 0,5; 0,6; 0,$7 ; 0,8$ e 1,0 Unidade por $20 \mathrm{~min}$ a $37^{\circ} \mathrm{C}$.

A melhor concentração de enzima EcoRI $(0,4 \mathrm{U})$ foi utilizada para digerir $6,0 \mu \mathrm{g}$ de DNA plasmidial por $20 \mathrm{~min}$, e o gel contendo o fragmento foi cortado sob UV no menor tempo de exposição para evitar possíveis mutações. O fragmento isolado foi purificado pelo kit "QIAquick Gel Extration Kit" (Qiagen). A quantificação foi feita em gel de agarose 1,0\% (p/v) em TBE 1X. 
Os vetores pCambia 1300 e pCambia 2300 (Cambia GPO Box 3200, Canberra ACT 2601, Austrália) foram totalmente digeridos com Hindlll e EcoRI para receberem o cassete de expressão isolado de pFFatacina.

Para ligação, transformação e confirmação da construção seguiu-se os procedimentos descritos no item 3.5.1. Confirmação por sequenciamento foi feita por PCR com "primers" especialmente construídos conforme sítios de clonagem dos vetores pCambia.

Com a comprovação das construções, os DNA plasmidiais, pCatacina 1300 e pCatacina 2300 , foram purificados por método de lise alcalina usando o kit "Plasmid Mini Kit" (Qiagen). A quantificação foi feita em gel de agarose 1,0\% $(\mathrm{p} / \mathrm{v})$ em TBE 1X, e o DNA estocado, a uma concentração de pelo menos 1 $\mu \mathrm{g} / \mu \mathrm{L}$ em água esterilizada, $\mathrm{a}-20^{\circ} \mathrm{C}$.

Esses vetores também foram inseridos nos vetores binários de Agrobacterium tumefaciens LBA4404 (Hoekema et al., 1983) e EHA105 (Hood et al., 1993).

\subsubsection{Cepas bacterianas}

Durante as etapas de clonagem, foram utilizadas as cepas bacterianas E. coli DH5 $\alpha$ (Hanahan, 1983) e A. tumefaciens LBA4404 (Hoekema et al., 1983) e EHA105 (Hood et al., 1993).

\subsubsection{Análise dos transformantes bacterianos ("Screening" por PCR)}

A análise das colônias transformantes foi realizada via PCR: as colônias foram repicadas em uma placa, antes da amplificação.

Os clones referentes às contruções pFFatacina, pCatacina 1300 e pCatacina 2300 foram analisados diretamente utilizando-se os oligonucleotídeos: 5' - GCT GTT CAG CTA GCC AGT CC - 3' e 5' - TTT GGG AAG 
TCA GGC ATG TT - 3', os quais amplificam um fragmento de 350pb (Tabela 4), referente à posição interna do gene atacina $A$.

Em todas as reações de PCR utilizou-se o seguinte protocolo:

Cada reação (25 $\mu \mathrm{L})$ continha 1 colônia bacteriana, $10 \mathrm{mM}$ TRIS-HCL $(\mathrm{pH}$ 8,4), $50 \mathrm{mM} \mathrm{KCl}, 3,0 \mathrm{mM} \mathrm{MgCl}, 50 \mu \mathrm{M}$ de cada dNTP, 1,0 U de Taq polimerase (Invitrogen ${ }^{\mathrm{TM}}$ ) e 3,5 pmoles de cada iniciador específico para o gene atacina $A$. A mistura foi coberta com óleo mineral esterilizado e submetida à desnaturação ( 3 min a $94^{\circ} \mathrm{C}$ ) seguida de 40 ciclos de amplificação (1 min a $94^{\circ} \mathrm{C} ; 1,5$ min a $55^{\circ} \mathrm{C}$ e 1 min a $72^{\circ} \mathrm{C}$ ) e à uma extensão final (4 min a $72^{\circ} \mathrm{C}$ ), em termociclador MJ Research. Os produtos das reações de PCR foram submetidos à eletroforese em TBE $1 \mathrm{X}$ em gel de agarose $1,0 \%(\mathrm{p} / \mathrm{v})$ e visualizados após coloração com brometo de etídeo $\left(1 \mathrm{mg}^{\left.100 \mathrm{~mL}^{-1}\right)}\right.$ sob luz UV.

\subsection{Construção dos oligonucleotídeos iniciadores ("primers”)}

Foram construídos dois pares de "primers" para o gene atacina $A$, os quais amplificam fragmentos de 350 pb e 200 pb, e um par para a região do sítio de clonagem dos vetores pCambia. As construções foram feitas utilizandose o programa Primer3 Output (Tabela 3).

As seqüências do gene atacina $A$ foram avaliadas em pAtacina (pBlueScript) e em pFFatacina. Houve amplicações de fragmentos conforme o esperado para esse gene. A seqüência MCS de pCambia foi também avaliada para as construções pCatacina 1300 e pCatacina 2300, havendo amplificação de uma seqüência de $\sim 2,15 \mathrm{~kb}$, tamanho esperado para o produto, correspondendo ao cassete de expressão P35S35S-atacinaA-T35S, clonado nos vetores pCambia 1300 e pCambia 2300 . 
Tabela 3. Seqüência de oligonucleotídeos iniciadores ("primers") construídos visando às análises por PCR.

\begin{tabular}{cccc}
\hline Gene & Posição & Seqüência $\left(5^{\prime} \Rightarrow 3^{\prime}\right)$ & Produto $(\mathrm{pb})$ \\
\hline atacina $A$ & 487 & ACA TCA GCG CTA AAG CCT TC & 199 \\
& $685 \mathrm{c}^{\mathrm{a}}$ & GTG GTG GGA CTA CGG AAC AC & \\
& 186 & GCT GTT CAG CTA GCC AGT CC & 350 \\
atacina A & $535 \mathrm{c}$ & TTT GGG AAG TCA GGC ATG TT & \\
& & \\
$\begin{array}{c}\text { Produto de clonagem em } \\
\text { MCS de pCambia }\end{array}$ & Forward & TGC TTC CGG CTC GTA TGT TG & \\
& Reverse & GCG AAA GGG GGA TGT GCT GC & \\
\hline
\end{tabular}

${ }^{\mathrm{a}} \mathrm{C}=$ fita complementar

\section{6- Seqüenciamento}

O plasmídeo pBlueScript com o gene atacina $A$ (pAtacina) e as construções pCatacina 1300 e pCatacina 2300 foram seqüenciadas.

Para o pBlueScript foram utilizados "primers" universais M13, enquanto para as construções pCatacina 1300 e 2300 foram utilizados "primers" específicos (F ou R) para a região do MCS dos vetores pCambia (Tabela 3 ).

Os plasmídeos foram extraídos utilizando-se o método de lise alcalina, os RNAs foram digeridos com RNAse e quantificados.

O seqüenciamento automático (sequenciador de DNA ABI PRISM 377) foi realizado no Departamento de Entomologia, Fitopatologia e Zoologia Agrícola da ESALQ, sob a supervisão do Prof. Dr. Luiz Eduardo Aranha Camargo.

A reação de seqüenciamento foi realizada usando-se os procedimentos descritos no manual do kit "DYEnamic ${ }^{\mathrm{TM}}$ ET Teminator Cycle Sequencing Kit" (Amersham Biosciences). Em tubos de 0,2 $\mathrm{mL}$ foram 
adicionados $2 \mu \mathrm{L}$ de "sequencing premix reagent" (que contêm dNTP, terminadores ddNTPs associados às substâncias fluorescentes e Thermo Sequenase $^{\mathrm{TM}}$ II DNA polimerase), $1 \mu \mathrm{L}$ de "primer" $\mathrm{F}$ ou $\mathrm{R}$ (3,0 pmoles), $1 \mu \mathrm{L}$ de DNA plasmidial (200 a $500 \mathrm{ng}$ ) e água esterilizada (q.s.p.) para um volume final de 10,0 $\mu \mathrm{L}$. Para os vetores pCatacina 1300 e pCatacina 2300, a concentração plasmidial foi de $1 \mu \mathrm{g} /$ reação. A seguinte reação de amplificação (30 ciclos) foi utilizada: $95^{\circ} \mathrm{C}$ por $20 \mathrm{~s}, 50^{\circ} \mathrm{C}$ por $15 \mathrm{~s}, 60^{\circ} \mathrm{C}$ por $60 \mathrm{~s}$, em termociclador MJ Research.

Após a reação, as amostras foram transferidas para microtubos de 0,65 $\mathrm{mL}$ e adicionou-se $1 \mu \mathrm{L}$ (1/10 volume) de acetato de sódio/EDTA (1,5 M $\mathrm{pH}>8,0 / 259 \mathrm{mM}$ ) e $40 \mu \mathrm{L}$ de etanol 95\%, misturando-se bem por vortex. A mistura permaneceu por $15 \mathrm{~min}$ à temperatura ambiente (escuro) e foi centrifugada a $13000 \mathrm{rpm}$ por $30 \mathrm{~min}$ à temperatura ambiente. $\mathrm{O}$ sobrenadante foi cuidadosamente descartado e o precipitado lavado com $250 \mu \mathrm{L}$ de etanol $70 \%$ (recém preparado). Centrifugou-se por mais $5 \mathrm{~min}$ sob as mesmas condições e o sobrenadante foi descartado. Os tubos, com as tampas abertas, foram colocados por $1 \mathrm{~min}$ em termociclador, previamente aquecido a $90^{\circ} \mathrm{C}$ para a completa evaporação da água.

Para o sequenciamento, as amostras foram ressuspensas em $3 \mu \mathrm{L}$ do corante "formamide loading dye", e 1,5 $\mu \mathrm{L}$ da amostra foi aplicada no gel.

As colônias com a seqüência desejada foram repicadas e estocadas em glicerol $\mathrm{a}-80^{\circ} \mathrm{C}$.

\subsection{Plasmídeos}

$\mathrm{Na}$ etapa de otimização dos parâmetros de transformação por biobalística, foram utilizados os vetores pBI426 (W. Crosby, Plant Biotechnology Institute, Saskatoon, Canadá) e pFF19G (Timmermans et al., 1990). 
O vetor pBI426 carrega a fusão uidA::neo (Datla et al., 1991) entre o gene repórter (uidA - $\beta$-glucuronidase) (Jefferson et al., 1987) e o marcador de seleção (neo - resistência a canamicina) (Bevan, 1984), sob o controle do promotor 35S do vírus do mosaico da couve-flor (CaMV) duplicado e adicionado da região 5 ' não traduzida do vírus do mosaico da alfafa (AMV), contendo o terminador do gene da nopalina sintase (NOS-T) de Agrobacterium tumefaciens.

O vetor pFF19G (Timmermans et al., 1990) carrega o gene uidA dirigido pelas seqüências promotoras (duplicado) e terminadoras $35 \mathrm{~S}$ do CaMV.

Os plasmídeos foram mandidos em E. coli (DH5 $\alpha$ ) (Hanahan, 1983), extraídos e purificados pelo método de lise alcalina usando-se o kit "Plasmid Mini Kit” (Qiagen).

Os vetores pFF19G e pBI426 estão representados nos Anexos A e B, respectivamente.

\subsection{Transformação por biobalística}

Foi utilizado o equipamento PDS 1000/He (Bio Rad), empregando gás Hélio à alta pressão como gerador de onda de choque para aceleração de micropartículas, detalhadamente descrito em Kikkert (1993).

A precipitação do DNA sobre as micropartículas de tungstênio M10 (Sylvania) foi realizada pelo método $\mathrm{CaCl}_{2}$ /espermidina descrito em Smith et al. (1992), Aragão et al. (1996) e Brasileiro \& Carneiro (1998). A umidade relativa do ar foi inferior a $40 \%$ e o vácuo na câmara do aparelho foi superior a $65 \mathrm{~mm}$ de $\mathrm{Hg}$.

A fim de estabelecer as condições mais adequadas para a transformação de Passiflora foram realizados experrimentos preliminares, de acordo com o recomendado por Sanford (1993).

Parâmetros físicos como pressão de gás Hélio em combinação com distâncias de vôo das micropartículas foram avaliados usando-se a expressão 
transiente de GUS (uidA). Os parâmetros de distâncias entre o disco de ruptura e macrocarreador e entre a membrana macrocarreadora e a tela de retenção foram fixadas em 6,35 $\mathrm{mm}$ e $10 \mathrm{~mm}$, respectivamente.

Parâmetros biológicos, fonte e idade de explante, foram avaliados para a expressão transiente de GUS.

As condições que resultarm em níveis mais elevados de expressão transiente foram empregadas nos experimentos posteriores de transformação, nominalmente: $800 / 6,5$ ou 100/9,5 (psi de gás Hélio/cm de distância de vôo dos microprojéteis) e explantes do tipo calo com até 10 dias ou discos foliares de 3 dias.

Os experimentos de bombardeamento foram realizados usando-se o tratamento selecionado na fase de otimização (itens 3.2 e 3.3), isto é, meio $\operatorname{MSB}(\mathrm{A})$ : MS contendo BA $(0,5 \mathrm{mg} / \mathrm{L}), 5 \%$ de água de coco e $0,6 \%$ de agar; e agentes seletivos (canamicina ou higromicina).

Primeiramente, os explantes (disco foliar, cotiledonar ou de segmentos entrenodais e hipocotiledonares) foram cultivados em meio $\mathrm{MSB}(\mathrm{A})$ por 1 a 10 dias (dependendo do explante). Estes materiais foram posicionados na região central da placa de petri $(9 \times 1,5 \mathrm{~cm}, 50 \mathrm{~mL})$ e bombardeados. Posteriormente, foram transferidos para meio $\operatorname{MSB}(\mathrm{A})$, os quais permaneceram no escuro por 1 dia e 7 dias na luz. Após esse período, os explantes foram transferidos para meios contendo o agente seletivo adequado: $50 \mathrm{mg} / \mathrm{L}$ de canamicina [MSB(A)K] ou $3 \mathrm{mg} / \mathrm{L}$ de higromicina $[\mathrm{MSB}(\mathrm{A}) \mathrm{H}]$.

Os explantes que apresentarem brotos foram individualizados em meio de enraizamento ( $1 / 2$ MS contendo $1,5 \%$ de sacarose) para "screening". Cada brotação individualizada foi analisada pelo teste de GUS histoquímico (Jefferson et al., 1987) e por PCR com "primers" específicos para o gene atacina A (Kang et al., 1996). 


\subsection{Ensaio histoquímico de GUS}

Os explantes foram analisados para detecção histoquímica da atividade da enzima $\beta$-glucuronidase $24 \mathrm{~h}$ após o bombardeamento, conforme descrito por Jefferson et al. (1987). O tecido foi infiltrado a vácuo durante $5 \mathrm{~min}$ com o tampão de reação contendo o substrato cromogênico 5-bromo-4-cloro-3indolil glucuronídeo (X-Gluc) (Chemica Alta DTD), preparado de acordo com McCabe et al. (1988), adicionado de $20 \%$ de metanol (v/v) a fim de suprimir a atividade de $\beta$-glucuronidases endógenas (Kosugi et al., 1990). Após incubação por $16 \mathrm{~h}$ a $37^{\circ} \mathrm{C}$, os pigmentos do tecido foram removidos por lavagens sucessivas com etanol $70 \%(\mathrm{v} / \mathrm{v})$ e os explantes observados sob microscópio estereoscópico. Este procedimento foi adotado para ensaios de expressão transiente e também para verificar a expressão estável nos regenerantes primários $\left(R_{1}\right)$, provenientes dos ensaios de transformação por biobalística.

\subsubsection{Localização anatômica da expressão transiente do gene uidA}

A análise histológica da expressão transiente foi realizada de maneira a identificar áreas de coincidência entre a formação de gemas e a expressão do gene uidA. Segmentos entrenodais, discos foliares e discos cotiledonares demonstrando reação positiva, ou seja, tecidos com pontos azuis, foram fixados e cortes manuais (20 a $25 \mu \mathrm{m}$ ) foram realizados.

\subsection{Análise molecular dos transformantes primários por reação em cadeia da polimerase (PCR)}

O DNA genômico foi isolado dos tecidos bombardeados com brotação, após 30 dias de cultivo, conforme descrito por Edwards et al. (1991). 
Posteriormente, foi usado o método de CTAB (Murray \& Thompson, 1980) usando-se folhas de plântulas adultas.

Cada mistura de reação ( $25 \mu \mathrm{L})$ continha $15 \mathrm{ng}$ de DNA genômico, 10 $\mathrm{mM}$ TRIS-HCL ( $\mathrm{pH} 8,4$ ), $50 \mathrm{mM} \mathrm{KCl}, 3,0 \mathrm{mM} \mathrm{MgCl}_{2}, 50 \mu \mathrm{M}$ de cada dNTP, 1,0 $U$ de Taq polimerase (Invitrogen ${ }^{\mathrm{TM}}$ ) e 3,5 pmoles de cada iniciador específico para o gene atacina $A$ (Tabela 4). A mistura foi coberta com óleo mineral esterilizado e submetida à desnaturação $\left(5 \mathrm{~min}\right.$ a $\left.95^{\circ} \mathrm{C}\right)$ seguida de 35 ciclos de amplificação $\left(1 \mathrm{~min}\right.$ a $95^{\circ} \mathrm{C} ; 40 \mathrm{~s}$ a $65^{\circ} \mathrm{C}$ e $30 \mathrm{~s}$ a $\left.72^{\circ} \mathrm{C}\right)$ e à extensão final $(5 \mathrm{~min}$ a $72^{\circ} \mathrm{C}$ ) em termociclador MJ Research. Os produtos das reações de PCR foram submetidos à eletroforese em TBE $1 \mathrm{X}$ em gel de agarose $1,0 \%(p / v)$, visualizados após coloração com brometo de etídeo $\left(1 \mathrm{mg}^{1} 100 \mathrm{~mL}^{-1}\right)$ sob luz UV e fotografados (Gel Doc 2000'M , Bio Rad).

Tabela 4. Seqüência de oligonucleotídeos iniciadores ("primers") utilizados nas análises por PCR para confirmação da transgenia.

\begin{tabular}{cccc}
\hline Gene & Posição & Seqüência $\left(5^{\prime} \Rightarrow 3^{\prime}\right)$ & Produto $(\mathrm{pb})$ \\
Atacina $A$ & 186 & GCT GTT CAG CTA GCC AGT CC & 350 \\
& $535 \mathrm{c}^{\mathrm{a}}$ & TTT GGG AAG TCA GGC ATG TT & \\
Atacina A & 186 & GCT GTT CAG CTA GCC AGT CC & 500 \\
& $685 \mathrm{c}$ & GTG GTG GGA CTA CGG AAC AC & \\
\hline
\end{tabular}

${ }^{\mathrm{a}} \mathrm{C}=$ fita complementar 


\section{RESULTADOS E DISCUSSÃO}

\subsection{Obtenção do material vegetal}

Foi obtida uma população de 70 indivíduos a partir da germinação in vitro de sementes "Sul Brasil" (Fgura 3A-C), Esta foi repicada mensalmente por estaquia (Figura 3D) visando obter material vegetal suficiente para fim de otimização dos protocolos de organogênese $e$ agente seletivo e, posteriormente, para transformação genética.

\subsection{Morfogênese in vitro}

\subsubsection{Organogênese direta}

Em todas as combinações de fitorreguladores houve uma resposta eficiente na indução de brotos (Figuras 4 e 5), confirmando a via de organogênese direta. Observou-se que pelo menos $65 \%$ dos explantes foliares inoculados responderam com formação de gemas que cobriram cerca de 20 a $50 \%$ da área do explante. Notas, em média, superiores a 20 (10-50) foram obtidas em relação à qualidade dos brotos.

Pela análise estatística, não houve diferença significativa entre os tratamentos ao nível de $5 \%$ de probabilidade, dentro de cada recipiente (Figura 4). No entanto, houve diferença significativa entre recipientes, quando a análise conjunta foi realizada. A inoculação em tubo foi melhor, com $96 \%$ dos explantes 


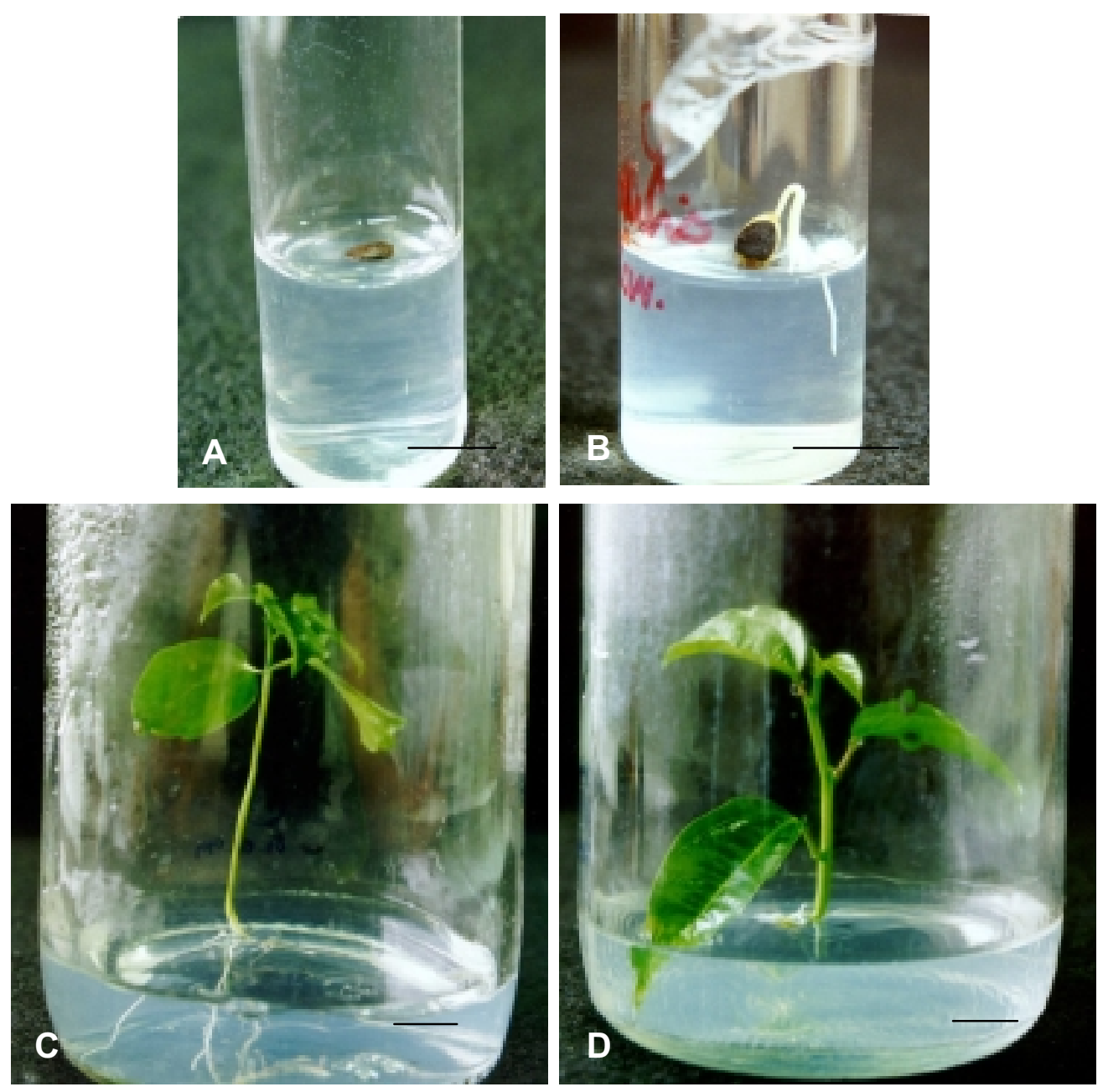

Figura 3 - Germinação de sementes in vitro de Passiflora edulis Sims f. flavicarpa Deg., população Sul Brasil. *

*A- em seguida à inoculação; B- após 15 dias; C- após 30 dias; Dplântula obtida por estaquia. Barras $=1,0 \mathrm{~cm}$. 


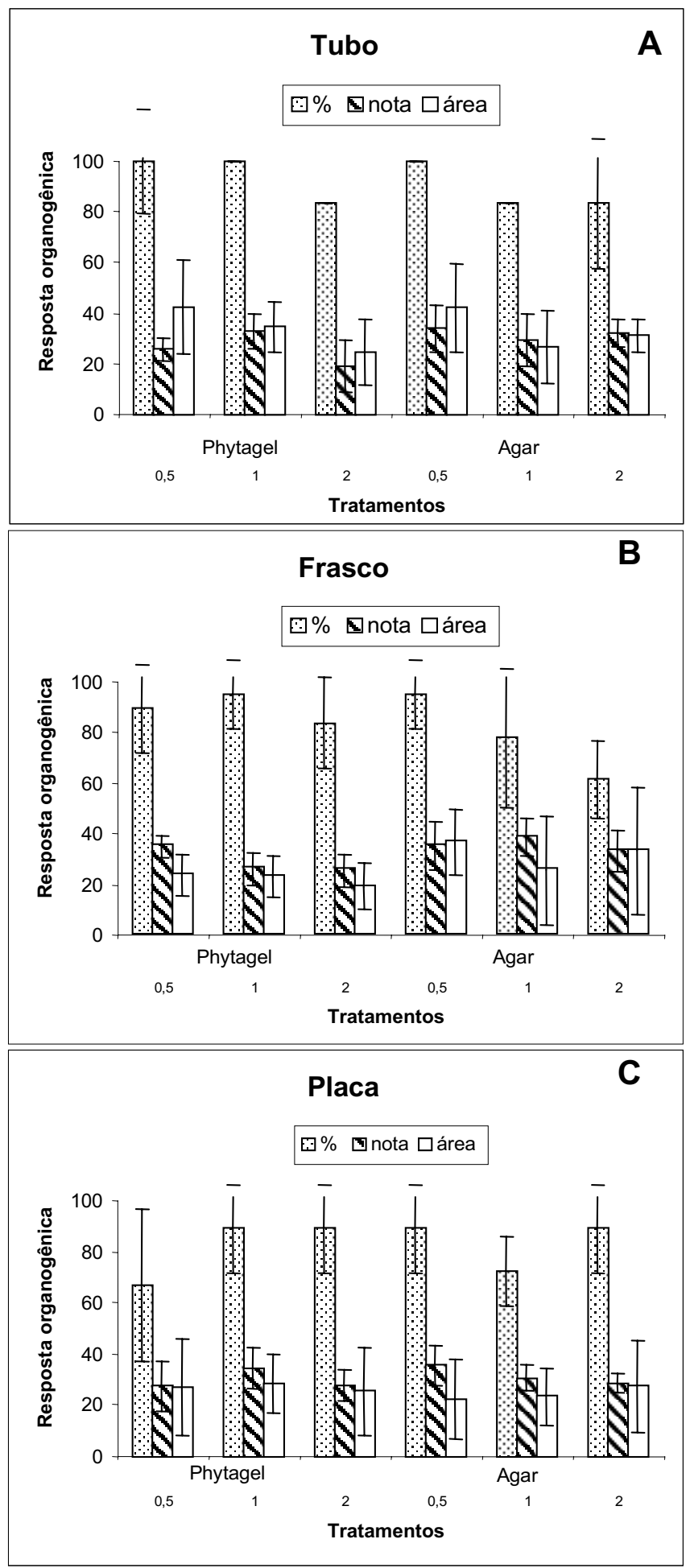

Figura 4 - Resposta organogênica a partir de discos foliares de Passiflora edulis Sims f. flavicarpa Deg., população Sul Brasil, sob tratamento fatorial: recipientes (A- tubo, B- frasco, C- placa), concentrações de BA (0,5; 1,0 e 2,0 mg/L), agentes solidificantes (phytagel e agar).*

* Variáveis avaliadas: porcentagem de explantes responsivos (\%), nota e área ocupada por gemas no explante. 


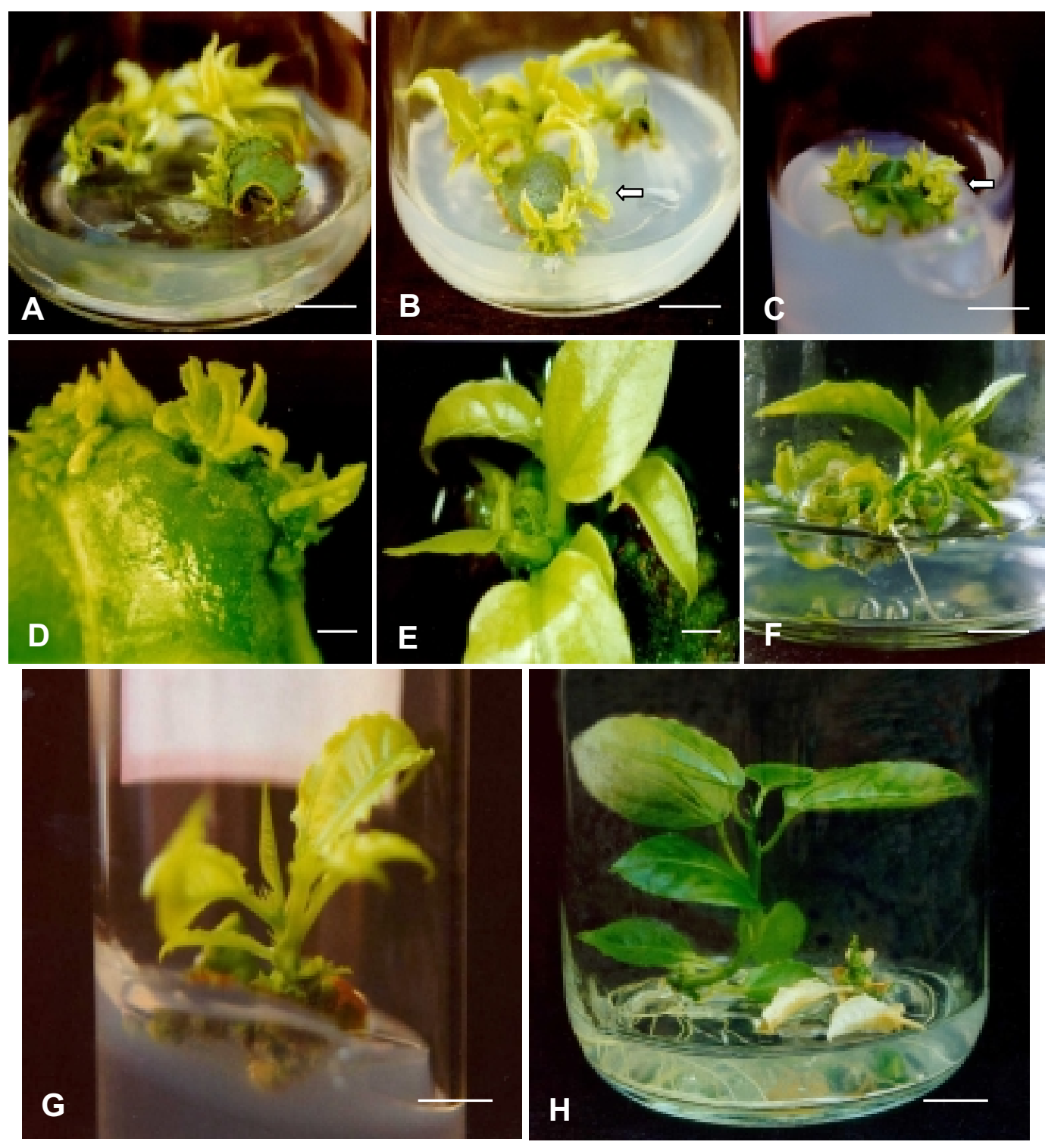

Figura 5 - Organogênese direta a partir de disco foliar de Passiflora edulis Sims f. flavicarpa Deg., população Sul Brasil.*

*A- frasco: $2,0 \mathrm{mg} / \mathrm{L}$ de $\mathrm{BA}, 5 \%$ água de coco, $0,18 \%$ phytagel aos 30 dias de cultivo; B- frasco: $0,5 \mathrm{mg} / \mathrm{L}$ de $\mathrm{BA}, 5 \%$ água de coco, $0,6 \%$ agar aos 30 dias (seta indica o aglomerado de brotos); C- tubo: $1 \mathrm{mg} / \mathrm{L}$ de $\mathrm{BA}, 5 \%$ água de coco, 0,6\% agar aos 30 dias (seta indica o aglomerado de brotos na região da nervura); D- detalhe dos brotos na borda do disco foliar aos 20 dias; E- detalhe de um broto com gema caulinar aos 30 dias; F e G- enraizamento dos brotos aos 40 dias; $\mathrm{H}$ - plântula regenerada aos 50 dias. Barras iguais a $1,0 \mathrm{~cm}(\mathrm{~A}, \mathrm{~B}$, $\mathrm{F} \mathrm{e} \mathrm{H}) ; 0,65 \mathrm{~cm}(\mathrm{C}) ; 0,87 \mathrm{~cm}$ (D e E); e 0,50 cm (G). 
apresentando resposta organogênica, contra 86 e $82 \%$ mostrados pelos tratamentos em frasco e placa, respectivamente. Para área do disco foliar, novamente, a cultura em tubo mostrou-se superior (43\%) em relação à em frasco $(34 \%)$ e placa $(33,5 \%)$ (Tabela 5$)$.

A organogênese teve início após 5 a 6 dias na borda do disco foliar, com formação de estruturas diferenciadas (pequenas gemas). Aos 10 dias, ocorreu a proliferação acentuada dessas estruturas e, eventualmente observaram-se pequenos brotos com folhas expandidas (Figura 5). A resposta iniciou-se, principalmente, na região da nervura central e estendeu-se por toda a borda do disco. Na maioria dos tratamentos observou-se a formação abundante de brotos em uma única região do disco (Figuras $5 B$ e $C$ ), o que dificultou a sua contagem.

Como dito, a formação de brotos adventícios a partir dos discos foliares foi influenciada pelo recipiente (Tabela 5). No entanto, o desenvolvimento posterior desses brotos não foi afetado por esta variável, ou seja, uma vez induzidos, os brotos desenvolveram-se normalmente.

Esses testes sugeriram que a composição de gases no interior dos recipientes não teve influência negativa na organogênese de maracujá, principalmente nos tubos, os quais foram selados com filme plástico. É sabido que dióxido de carbono e etileno se acumulam em recipientes selados durante a cultura in vitro, enquanto o oxigênio é reduzido, principalmente devido a gases emitidos durante o processo de manipulação dos explantes, sua inoculação e cultura (Buddendorf-Joosten \& Woltering, 1994). Em maracujá, esse efeito não foi observado, visto que os tubos proporcionaram a melhor resposta organogênica (Tabela 5).

No entanto, quando as placas foram seladas com filme plástico, somente rizogênese foi observada (dados não apresentados). Essa diferença pode ser explicada por não haver competição entre os explantes, já que somente 1 explante foi inoculado por tubo. Além do espaço limitado na placa, 3 explantes competiam pelos nutrientes do meio de cultura. $O$ fato de existir 
competição entre os explantes pelos componentes do meio parece ser importante, já que o experimento em tubos foi melhor, com mais de $90 \%$ dos explantes inoculados com resposta organogênica e mais de $40 \%$ da área do explante com brotação, mesmo sendo selados com filme plástico.

Trabalhos relatam a influência do etileno na formação de raiz in vitro em muitas espécies de planta (Phatak et al., 1981; Robbins et al., 1983; Pitts et al., 1999; Clark et al.; 1999). Os resultados do presente estudo sugerem que, também em maracujá, o etileno em excesso induz à rizogênese. No entanto, Reis (2001) verificou o marcante efeito inibitório do etileno na morfogênese in vitro de maracujá amarelo, em meio suplementado com ACC (precursor de etileno).

Em experimentos preliminares com maracujá amarelo e em híbridos australianos (Dornelas \& Vieira, 1994; Hall et al., 2000), os autores verificaram o efeito da água de coco na produção de gemas adventícias. O meio MS acrescido de BA e $10 \%$ de água de coco, com explantes cultivados sob luz, foram ideais para promover a organogênese direta. No presente trabalho, no entanto, menores concentrações de BA $(0,5 \mathrm{mg} / \mathrm{L})$ e de água de coco $(5 \%)$ levaram a uma alta formação de brotos por explante, podendo chegar a 50 . Essa quantidade se assemelha ao encontrado por Dornelas \& Vieira (1994).

Welander \& Maheswaran (1992) relatam que os agentes solidificantes podem afetar os potencias osmóticos e a taxa de difusão de nutrientes contidos nas formulações de meio de cultura. Isso se confirma no presente estudo pois, o meio solidificado com agar mostrou-se superior quanto ao vigor dos brotos, quando comparado ao observado com phytagel.

O enraizamento foi observado em meio $1 / 2$ MS contendo $1,5 \%(p / v)$ de sacarose (Figuras $5 \mathrm{~F} \mathrm{e} \mathrm{G}$ ) e plantas normais foram obtidas (Figura $5 \mathrm{H}$ ) em todos os tratamentos.

A otimização do protocolo de organogênese direta para a população Sul Brasil de maracujá amarelo foi de fundamental importância pois permitiu a execução de todos os demais experimentos. Sendo assim, o meio MS contendo 
as combinações BA $(0,5 \mathrm{mg} / \mathrm{L})$, água de coco $(5 \%)$ e solidificado com agar, denominado meio $\operatorname{MSB}(A)$, foi aplicado nos ensaios subsequentes de agente seletivo e otimização da fonte e idade de explante visando à transformação por biobalística. As inoculações foram feitas em placa pela facilidade de manuseio.

Tabela 5. Análise conjunta da resposta organogênica em relação aos recipientes utilizados.

\begin{tabular}{lccc}
\hline Recipiente & \multicolumn{3}{c}{ Resposta } \\
\cline { 2 - 4 } & $\begin{array}{c}\% \text { de } \\
\text { explantes }\end{array}$ & $\begin{array}{c}\text { Área de } \\
\text { regeneração (\%) }\end{array}$ & $\begin{array}{c}\text { Nota } \\
\text { (vigor do broto) }\end{array}$ \\
\hline Tubo & $95,6 \mathrm{a}$ & $43,2 \mathrm{a}$ & $27,1 \mathrm{a}$ \\
Frasco & $85,7 \mathrm{~b}$ & $34,0 \mathrm{~b}$ & $25,7 \mathrm{a}$ \\
Placa & $81,9 \mathrm{~b}$ & $33,5 \mathrm{~b}$ & $25,0 \mathrm{a}$ \\
\hline
\end{tabular}

Valores seguidos da mesma letra não diferem estatisticamente entre si pelo teste de Tukey, ao nível de $5 \%$ de probabilidade.

\subsubsection{Organogênese indireta}

Foi estabelecido um sistema de regeneração de parte aérea de maracujá via organogênese indireta a partir de segmentos entrenodais e de hipocótilos cortados transversalmente $(2 \mathrm{~mm})$. Essa via indireta foi confirmada por cortes histológicos e por microscopia de varredura (Figuras 6 e 7).

O explante sofreu expansão e calogênese em 3 dias, com aparecimento de estruturas foliares na sua base em 7 dias (Figura 6) em meio $\operatorname{MSB}(\mathrm{A})$ : $M S$ com $0,5 \mathrm{mg} / \mathrm{L}$ de $B A$ e $5 \%$ água de coco. Aos 18 dias, estas estruturas cobriram inteiramente a superfície do explante, com cerca de 300 por explante conforme verificado em microscopia de varredura (Figura 7). Formação semelhante foi observada por Biasi et al. (2000) também em explantes entrenodais de maracujazeiro, em concentrações de 1 a $4 \mathrm{mg} / \mathrm{L}$ de BA. Os autores observaram a proliferação de calo e formação de gemas 
adventícias de forma simulânea e contínua e o desenvolvimento assincrônico de brotos no explante.

Cerca de 95\% dos explantes inoculados apresentaram estruturas semelhantes a gemas, sem variação com o tipo de explante. No entanto, essas estruturas quando observadas em microscopia óptica e de varredura (Figura 7) indicaram ser formações foliares, sem a presença de gemas caulinares.

Estruturas foliares semelhantes foram registradas em explantes cotiledonares de Stylosanthes guianensis, após 30 dias de cultura em MS suplementado com 2,0 mg/L de BA (Appezzato-da-Gloria, 1998). A autora relatou que na superfície do calo de $S$. guianensis apareciam áreas verdes que, mais tarde, davam origem às estruturas foliares e às gemas caulinares. As análises histológicas sugeriram que as células subepidérmicas da região basal dessas estruturas entram em divisão formando novas áreas meristemáticas ou meristemóides, a partir dos quais as gemas caulinares se desenvolvem, estando portanto estritamente associadas à base das lâminas foliares.

Esse mesmo processo pode estar ocorrendo com Passiflora (Appezzato-da-Gloria, B. comunicação pessoal), como mostrado na Figura 7C$\mathrm{E}$, com áreas meristemáticas na região basal das estruturas foliares, e também pelo fato de brotos apareceram em alguns calos cultivados por mais de 20 dias em $1 / 2$ MS, e quando individualizados, enraizaram e plantas inteiras foram geradas (Figura 6D). Dornelas \& Vieira (1994) e Biasi et al. (2000) relatam que elongação dos brotos foi prejudicada quando estes foram induzidos com altas concentrações de BA (2 mg/L ou mais), necessitando de subcultivo em meio sem regulador para se desenvolver uma planta completa.

A presença dessas estruturas foliares foi muito variável de um explante para outro, tanto oriundas de hipocótilo como de segmento entrenodal. Isso se deve provavelmente à variação genética e epigenética existente entre as plantas doadoras de explante. É sabido que a morfogênese decresce quando células, tecidos e órgãos vegetais são subcultivados in vitro por longo tempo, ou seja, a capacidade de regeneração de brotos ou embriões somáticos 


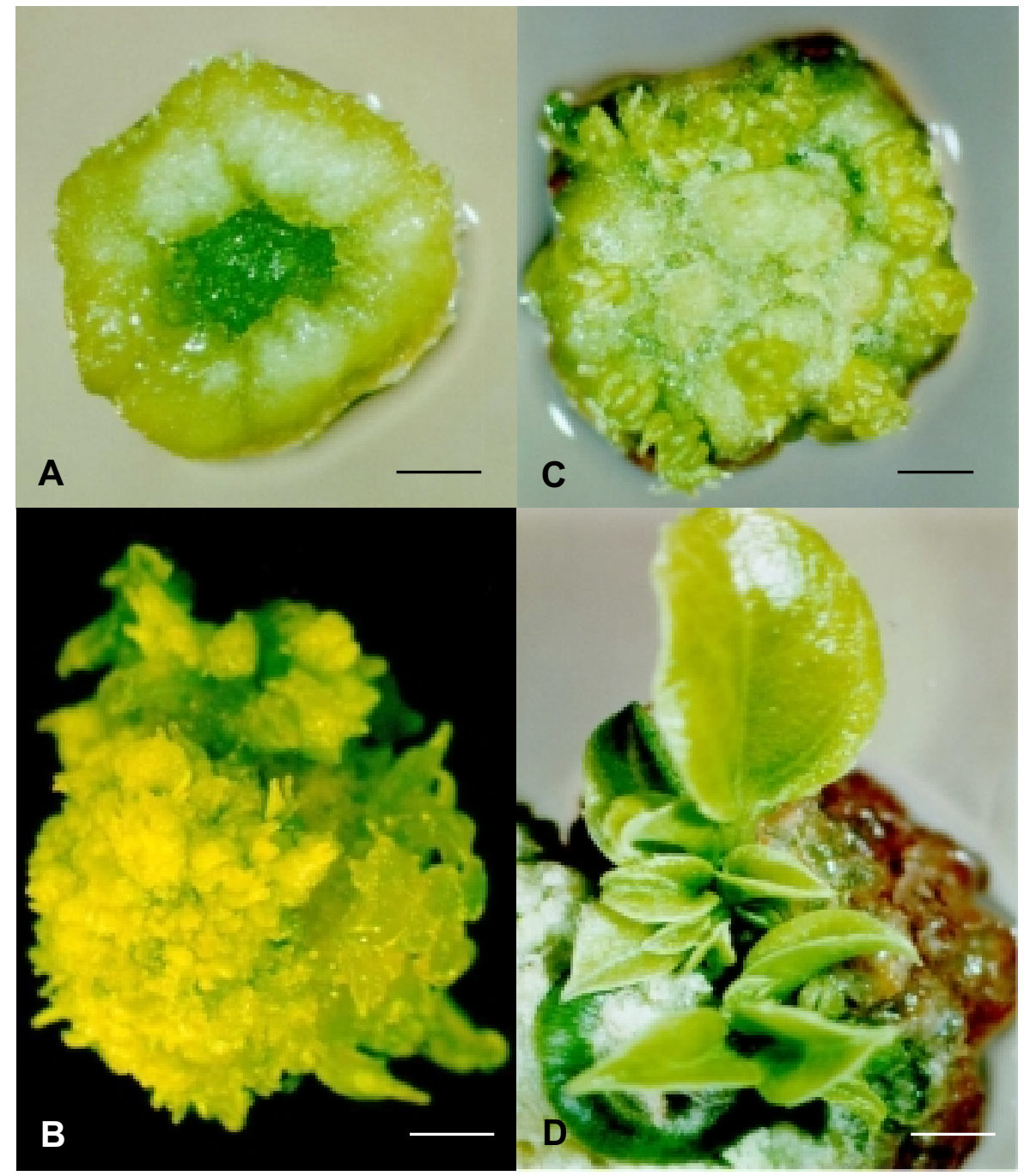

Figura 6 - Organogênese indireta a partir de segmentos entrenodais de $P$. edulis Sims f. flavicarpa Deg.*

${ }^{*} A$ - explante aos 8 dias de cultivo em meio $M S B(A)$, iniciando a formação de brotos (barra $=560 \mu \mathrm{m}$ ); B, C e D- aos 20 (barra = $520 \mu \mathrm{m}), 27$ (barra $=620 \mu \mathrm{m})$ e 40 dias de cultivo (barra $=870$ $\mu \mathrm{m})$. 


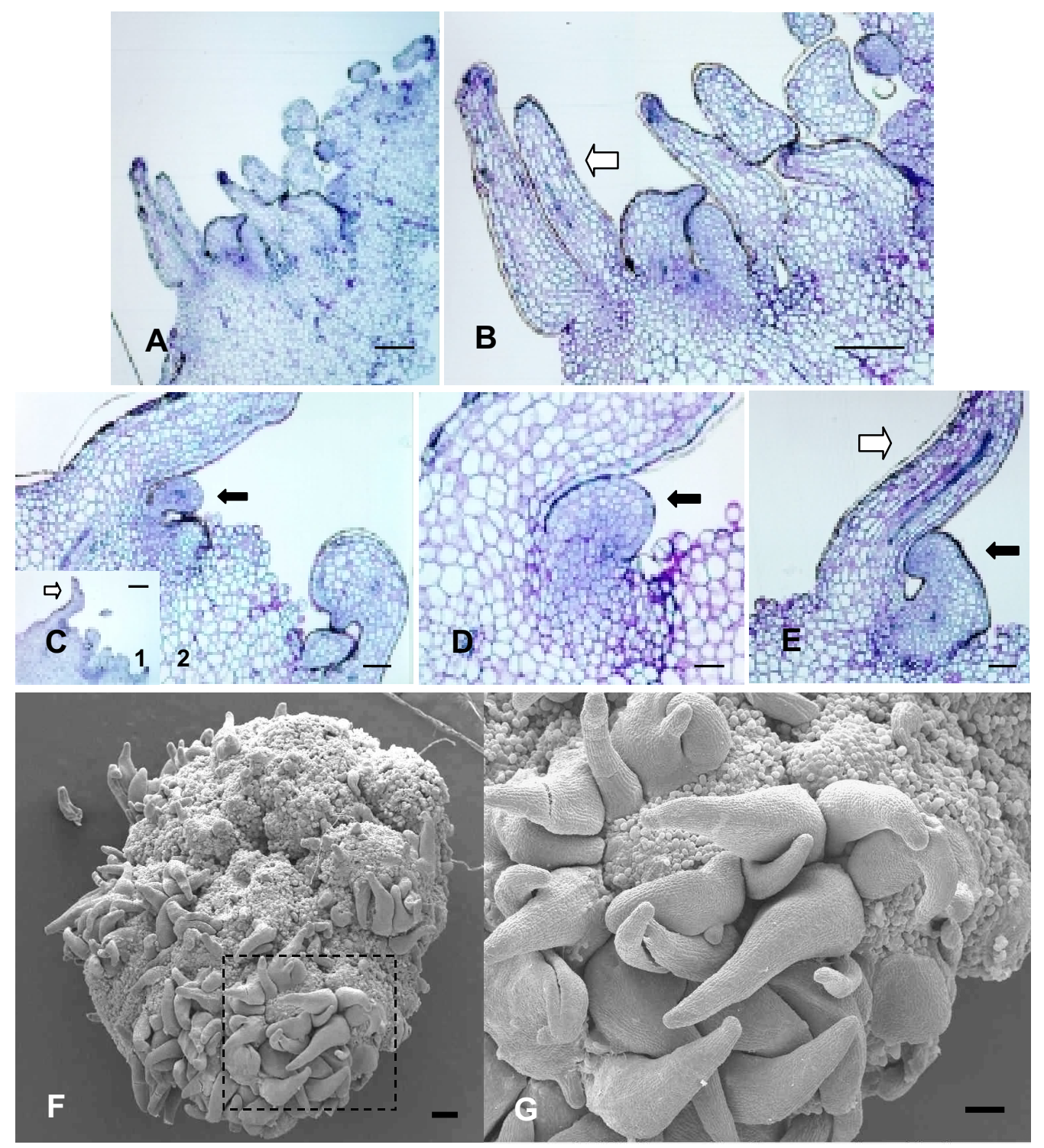

Figura 7 - Cortes histológicos (A, B, C, D e E) e microscopia eletrônica de varredura ( $\mathrm{F} \mathrm{e} \mathrm{G}$ ) de segmentos entrenodais de Passiflora edulis Sims f. flavicarpa Deg. aos 18 dias de cultura em $\operatorname{MSB}(\mathrm{A})$. $^{*}$

* As setas (branca) indicam estruturas foliares, e as setas (preta) indicam estruturas meristemáticas. Barras iguais a $165 \mu \mathrm{m}$ (A e B), 230 e $68 \mu \mathrm{m}$ (C1 e C2), $17 \mu \mathrm{m}$ (D), $68 \mu \mathrm{m}$ (E), $200 \mu \mathrm{m}$ (F) e $100 \mu \mathrm{m}$ (G). 
em resposta a um estímulo específico é comprometida (George, 1993; Collin \& Edwards, 1998; Gaspar et al., 2000). Essa hipótese se ajusta para explantes entrenodais de maracujá, já que o subcultivo da população foi feita mensalmente por estaquia, das quais os explantes foram excisados.

A proliferação simultânea de calos e estruturas diferenciadas caracteriza a via indireta de morfogênese. Apesar de haver indução de um grande número de estruturas diferenciadas em 18 dias, é necessário que estas sejam cultivadas por mais 20 a 30 dias em $1 / 2$ MS para o isolamento de brotos e desenvolvimento de plantas. Em comparação à via direta (item 4.2.1), o número de plantas geradas por explante é bastante reduzida. Faz-se necessário otimizar o sistema, inoculando-se explantes maiores (5 a $10 \mathrm{~mm}$ ), testar outras concentrações de BA (0 a $1 \mathrm{mg} / \mathrm{L}$ ) ou testar novos meios basais, como MSM, desenvolvido por Monteiro et al. (2000a).

Esse sistema, ainda que mostre somente estruturas foliares, se otimizado, poderá ser útil na propagação clonal da cultura, e nos trabalhos de transformação genética, uma vez que as estruturas cobrem totalmente o explante em apenas 18 dias (cerca de 300 estruturas/explante de $2 \mathrm{~mm}$ ), e pelo fato dessas se originarem, aparentemente, de camadas superficiais do tecido, sendo esta uma condição ideal para a transformação genética, tanto a partir de métodos diretos como de indiretos, potencializando a transferência de genes de interesse.

\subsection{Agente seletivo}

A Tabela 6 mostra a eficiência dos agentes seletivos canamicina, geneticina, higromicina e fosfinotricina levando à inibição ou bloqueio da organogênese direta em discos foliares de Passiflora edulis f. flavicarpa. A inibição iniciou-se na primeira semana, período em que a cultura permaneceu no escuro (Figura 8A). Quando esta foi exposta à luz, em poucos dias, os explantes tornaram-se cloróticos (Figura $8 \mathrm{~B}$ ). Essa resposta foi tão rápida 
quanto maior foi a concentração do agente. A maioria dos explantes cultivada na ausência de agente seletivo deram origem a brotos (Figura 8- A1 e B1, Tabela 6).

O antibiótico higromicina mostrou-se um agente seletivo potente, com redução na morfogênese a $5 \mathrm{mg} / \mathrm{L}$ (30\% com brotos). Diferença significativa foi detectada em relação ao controle (sem antibiótico) que mostrou mais de $85 \%$ dos explantes com brotação. Mais de $55 \%$ de morte foi registrada em meio contendo $5 \mathrm{mg} / \mathrm{L}$ de higromicina e inibição total da organogênese em concentrações acima de $10 \mathrm{mg} / \mathrm{L}$ (Tabela 6 ).

Em mandioca, a seleção de plantas transformadas por biobalística foi feita, inicialmente, com $7,5 \mathrm{mg} / \mathrm{L}$ de higromicina por 10 dias, aumentando-se para $15 \mathrm{mg} / \mathrm{L}$ por duas semanas e, após este período, a cultura foi mantida em 10 mg/L (Zhang et al., 2000). A freqüência de transformação nessas condições de cultura foi de 0,6 e 1,2\% para dois genótipos, MCol22 e TMS60444, respectivamente.

Para a seleção de plantas transgênicas de Passiflora, propõe-se a utilização inicial de 2 a $3 \mathrm{mg} / \mathrm{L}$ de higromicina que deve ser aumentada gradualmente até 10 a $15 \mathrm{mg} / \mathrm{L}$.

O antibiótico canamicina tem sido usado como agente seletivo em maracujá amarelo (Manders et al., 1994; Otoni, 1995; Silva, 1998). Segundo Silva (1998) a concentração de $50 \mathrm{mg} / \mathrm{L}$ de canamicina foi capaz de incrementar a regeneração adventícia de ramos de maracujá. Os explantes foliares mostraram elevada tolerância natural a canamicina, com regeneração esporádica de gemas e ramos adventícios e rizogênese quando subcultivados à concentração de $100 \mathrm{mg} / \mathrm{L}$. A inibição completa da organogênese in vitro de ramos e raízes foi observada na concentração de $150 \mathrm{mg} / \mathrm{L}$ desse antibiótico.

Os resultados do presente trabalho mostraram regeneração de brotos em meio com até $25 \mathrm{mg} / \mathrm{L}$. Acima de $50 \mathrm{mg} / \mathrm{L}$ foi observada somente expansão do explante, mas este manteve-se verde. Na concentração de $75 \mathrm{mg} / \mathrm{L}$, mais de $95 \%$ dos explantes mostraram total inibição da regeneração (Tabela 6). Os 


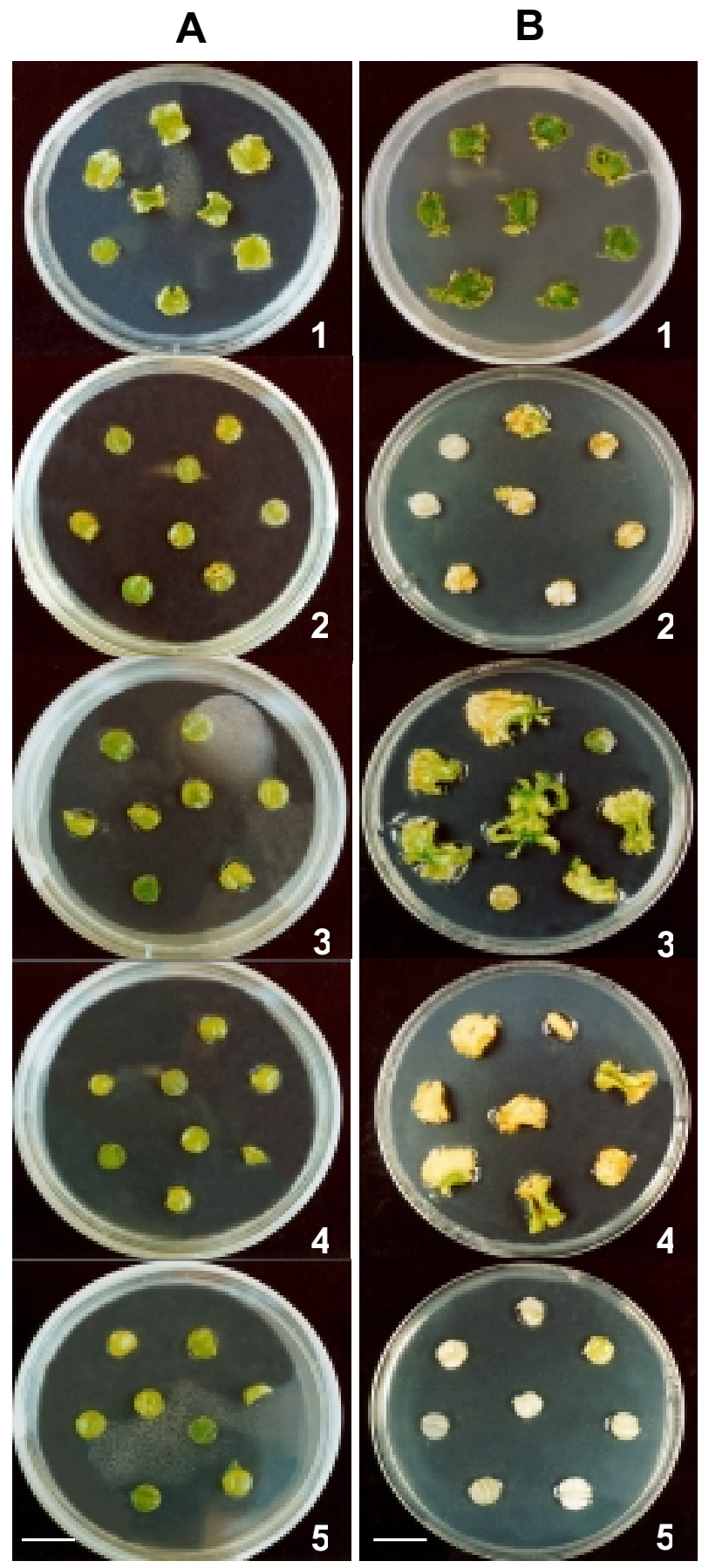

Figura 8 - Discos foliares de $P$. edulis Sims f. flavicarpa Deg. cultivados em $\mathrm{MSB}(\mathrm{A})$ suplementado com diferentes concentrações (em $\mathrm{mg} / \mathrm{L}$ ) de antibióticos ou herbicida (fosfinotricina), após 7 dias no escuro (A) e após 28 dias, sob luz (B).*

* Prancha A: 1- controle, 2- higromicina (25), 3- canamicina (100), 4- geneticina (50), 5- fosfinotricina (25). Prancha B: 1- controle, 2- higromicina (5), 3canamicina (5), 4- geneticina (5) e 5- fosfinotricina (2). Barras $=1,0 \mathrm{~cm}$. 
Tabela 6. Regeneração, expansão e morte de discos foliares de Passiflora edulis f. flavicarpa Deg., população Sul Brasil, em resposta a diferentes concentrações dos agentes seletivos: higromicina, canamicina, geneticina e fosfinotricina.

\begin{tabular}{|c|c|c|c|c|c|c|c|c|c|c|c|c|c|}
\hline \multirow{3}{*}{$(\mathrm{mg} / \mathrm{L})$} & \multicolumn{3}{|c|}{ Higromicina } & \multicolumn{3}{|c|}{ Canamicina } & \multicolumn{3}{|c|}{ Geneticina } & \multirow{3}{*}{$\begin{array}{c}\text { Concentração } \\
(\mathrm{mg} / \mathrm{L})\end{array}$} & \multirow{2}{*}{\multicolumn{3}{|c|}{$\begin{array}{l}\text { Fosfinotricina } \\
\text { Resposta (\%) }\end{array}$}} \\
\hline & \multicolumn{9}{|c|}{ Resposta (\%) } & & & & \\
\hline & Morte & Expansão & Broto & Morte & Expansão & Broto & Morte & Expansão & Broto & & Morte & Expansão & Broto \\
\hline 0,0 & $0,0 a$ & $12,5 a$ & $87,5 a$ & $0,0 a$ & $12,5 a b$ & $87,5 a$ & $0,0 a$ & $12,5 a$ & $87,5 a$ & 0,0 & $0,0 a$ & $12,5 a$ & $87,5 a$ \\
\hline 5,0 & $58,3 b$ & $12,5 a$ & $29,17 b$ & $12,5 a b$ & $0,0 \mathrm{~b}$ & $87,5 a$ & $12,5 \mathrm{ab}$ & $33,33 a b$ & $54,17 a b$ & 2,0 & $91,67 b$ & $8,33 a$ & $0,0 \mathrm{~b}$ \\
\hline 10,0 & $87,5 c$ & $0,0 a$ & $12,5 \mathrm{c}$ & 45,83abcd & $12,5 a b$ & $41,67 \mathrm{~b}$ & $29,17 a b$ & $0,0 a$ & $70,83 a b$ & 3,0 & $95,83 b$ & $4,17 a$ & $0,0 b$ \\
\hline 12,5 & $95,8 \mathrm{c}$ & $4,2 a$ & $0,0 \mathrm{c}$ & $62,5 \mathrm{bcd}$ & $12,5 \mathrm{ab}$ & $25 b c$ & $33,33 a b$ & $66,67 b$ & $0,0 c$ & 4,0 & $100 \mathrm{~b}$ & $0,0 a$ & $0,0 \mathrm{~b}$ \\
\hline 15,0 & $95,8 \mathrm{c}$ & $4,2 a$ & $0,0 \mathrm{c}$ & $33,33 a b c$ & $50 a$ & $16,67 \mathrm{~cd}$ & $45,83 \mathrm{abc}$ & $54,17 \mathrm{~b}$ & $0,0 c$ & 6,0 & $100 b$ & $0,0 a$ & $0,0 \mathrm{~b}$ \\
\hline 20,0 & $100,0 c$ & $0,0 a$ & $0,0 c$ & $12,5 a b$ & $16,67 a b$ & $10,83 \mathrm{~cd}$ & $58,33 \mathrm{bc}$ & $41,67 \mathrm{ab}$ & $0,0 c$ & 8,0 & $100 b$ & $0,0 a$ & $0,0 \mathrm{~b}$ \\
\hline 25,0 & $100,0 c$ & $0,0 a$ & $0,0 c$ & $58,33 \mathrm{bcd}$ & $37,5 a b$ & $4,17 \mathrm{~cd}$ & $100 c$ & $0,0 \mathrm{~b}$ & $0,0 c$ & 10,0 & $100 \mathrm{~b}$ & $0,0 a$ & $0,0 \mathrm{~b}$ \\
\hline 50,0 & $100,0 c$ & $0,0 a$ & $0,0 c$ & $79,17 \mathrm{~cd}$ & $20,83 b$ & $0,0 \mathrm{~d}$ & $100 c$ & $0,0 \mathrm{~b}$ & $0,0 c$ & 25,0 & $100 b$ & $0,0 a$ & $0,0 \mathrm{~b}$ \\
\hline 75,0 & $100,0 \mathrm{c}$ & $0,0 a$ & $0,0 \mathrm{c}$ & $95,83 d$ & $4,17 \mathrm{~b}$ & $0,0 \mathrm{~d}$ & $100 c$ & $0,0 \mathrm{~b}$ & $0,0 c$ & & & & \\
\hline 100,0 & $100,0 \mathrm{c}$ & $0,0 a$ & $0,0 c$ & $85,83 d$ & $4,17 b$ & $0,0 \mathrm{~d}$ & $100 c$ & $0,0 b$ & $0,0 \mathrm{c}$ & & & & \\
\hline
\end{tabular}

Os valores médios seguidos por diferentes letras, dentro de cada agente seletivo, são estatisticamente diferentes pelo teste de Tukey $(P<0,05)$. 
resultados de inibição completa assemelham-se aqueles encontrados por Manders et al. (1994) e Otoni (1995). A tolerância natural do disco foliar de maracujazeiro a concentrações superiores a $100 \mathrm{mg} / \mathrm{L}$ de canamicina encontrada por Silva (1998) pode ser atribuída à utilização de phytagel como agente solidificante. Chauvin et al. (1999) relataram que uma grande parte da resistência da planta à canamicina é devido à interação entre o agente solidificante e o antibiótico. Interação significativa entre 'canamicina x phytagel' em plantas de tabaco, tulipa e gladíolo foram relatadas.

Em meios solidificados com agar essa resposta não foi observada. No entanto, Silva (1998) ressalta que o uso de $150 \mathrm{mg} / \mathrm{L}$ de canamicina pode não ser a melhor estratégia para eliminar células ou tecidos organizados não transformados de Passiflora edulis, uma vez que a pressão de seleção imposta pode inibir drasticamente a diferenciação de células transformadas. A utilização de $50 \mathrm{mg} / \mathrm{L}$ de canamicina para a seleção inicial de plantas transgênicas de maracujá, população Sul Brasil, é aqui recomendada, podendo ser aumentada gradativamente até $100 \mathrm{mg} / \mathrm{L}$.

A geneticina foi usada para seleção em ensaios transformação de arroz (Dekeyser et al., 1989) e Arabidopsis thaliana (Schmidt \& Willmitzer, 1988). Porém, em outras plantas como beterraba (Catlin, 1990), maçã (Norelli \& Aldwinckle, 1993) e olmo siberiano (Kapaun \& Cheng, 1999), esse antibiótico mostrou-se altamente tóxico a $4 \mathrm{mg} / \mathrm{L}$, matando rapidamente as células não transformadas, podendo também inibir as células transformadas de regenerarem brotos.

No presente estudo, não foi observada toxicidade da geneticina (Tabela 6), havendo necessidade de pelo menos $25 \mathrm{mg} / \mathrm{L}$ para que houvesse a inibição total da organogênese. Brotos regenerados foram observados em meios contendo 5 e $10 \mathrm{mg} / \mathrm{L}$ de geneticina e os explantes mantiveram-se verdes e expandidos na concentração de $20 \mathrm{mg} / \mathrm{L}$ (42\%) (Figura 8 e Tabela 6). Esse antibiótico pode ser utilizado em substituição à canamicina, ou mesmo em 
associação, em alguma fase da regeneração, já que muitos problemas de regeneração e seleção podem ocorrer quando se utiliza canamicina.

Resultado bastante drástico foi observado com fosfinotricina, havendo completa inibição da regeneração de brotos na concentração de $2 \mathrm{mg} / \mathrm{L}$ (Figura 8 e Tabela 6). O gene bar ou pat é o gene mais freqüentemente utilizado como marcador seletivo na transformação de monocotiledôneas, o qual confere resistência aos herbicidas Basta e bialaphos, que contêm fosfinotricina (PPT). Nota-se que há uma variação na concentração de herbicida dependendo da espécie vegetal (Chen et al.; 1998a; Wright et al., 2001).

Neste trabalho, utilizou-se fosfinotricina pura (Sigma), enquanto outros autores utilizaram herbicidas que compõem a fosfinotricina como componente ativo da formulação. Essa foi, provavelmente, uma das causas da redução altamente significativa na organogênese de maracujazeiro, na menor concentração usada (2 mg/L).

Discos foliares de maracujá respondem diferentemente quanto à organogênese quando cultivados em meios com antibióticos (canamicina, geneticina e higromicina) e herbicida (fosfinotricina). Todos os agentes mostram-se efetivos na inibição da morfogênese in vitro em maracujá amarelo, no entanto, higromicina e fosfinotricina mostraram maior potencialidade nos experimentos de seleção, já que baixas concentrações dessas substâncias são suficientes para inibir a organogênese direta. Para a seleção com fosfinotricina, concentrações abaixo de $1 \mathrm{mg} / \mathrm{L}$ devem ser avaliadas, e conforme o tempo de subcultivo, é sugerido usar aumentos gradativos até $2 \mathrm{mg} / \mathrm{L}$.

\subsection{Construção dos cassetes de expressão}

\subsubsection{Etapa 1: Construção do vetor pFFatacina}

O gene atacina $A$ isolado de Trichoplusia ni (Kang et al., 1996) tem $1601 \mathrm{pb}$, contendo 2 introns e 3 exons (Genbank NCBI, U46130). O transcrito 
primário do RNAm (CDS), chamado de preproatacina, tem 1399pb e o cDNA $765 \mathrm{pb}$. A proteína atacina A é composta de 254 aminoácidos (Figura 9).

Para certificar-se do tamanho exato da seqüência e do respectivo mapa de restrição, o gene clonado em pBlueScript (pBS) foi seqüenciado. $O$ resultado mostrou homologia perfeita com a seqüência do gene depositada no banco de dados Genbank. Utilizou-se o programa BLASTn, e determinou se que o gene tem $\sim 1050 \mathrm{pb}$ (Figura 10).

Nesse alinhamento foi também incluída a seqüência do gene atacina $E$, de Hyalophora cecropia (Genbank NCBI, M34926), que é uma das formas acídicas do gene isolado desta espécie, o qual possui padrões similares de nucleotídeos e de peptídeos, com homologia com o de T. ni, e 63\% de identidade com a parte madura da proteína (Kang et al., 1996). O gene atacina $E$ foi introduzido em macieira (Ko et al.; 2000) e pereira (Reynoird et al., 1999), como alternativa para controlar a ferrugem do fogo, doença causada por Erwinia amylovora. Ensaios biológicos mostraram expressão do gene nessas plantas, as quais estão atualmente em ensaios de campo (Aldwinclke, H.: HSA1@cornell.edu). A homologia entre os 2 genes indica o potencial da atacina A para controlar doenças causadas por bactérias Gram negativas, como a Xanthomonas campestris pv. passiflorae.

O cDNA do gene (1050pb) foi isolado e inserido no vetor pFF19 $(4,2 \mathrm{~kb})$, que possui promotor e terminador para plantas (Figura 11). As enzimas de restrição Xbal e Pstl liberaram o gene atacina (1050pb $+4,2 \mathrm{~kb})$. A enzima Hindlll abriu o vetor tornando-o linear (5.25 kb) (Figura 11B). Estas clivagens comprovaram que a clonagem foi correta. A construção foi também confirmada por PCR, utilizando-se de "primers" do gene atacina $A$, os quais amplificaram um fragmento de 350pb (Figuras 11D e E).

$O$ vetor com o cassete de expressão foi chamado de pFFatacina $(5,25$ $\mathrm{kb}$ ), o qual contém o promotor $35 \mathrm{~S}$ duplicado, atacina $A$ e o terminador $35 \mathrm{~S}$ (Figura 11). O vetor pFFatacina foi utilizado para transformação de plantas de 


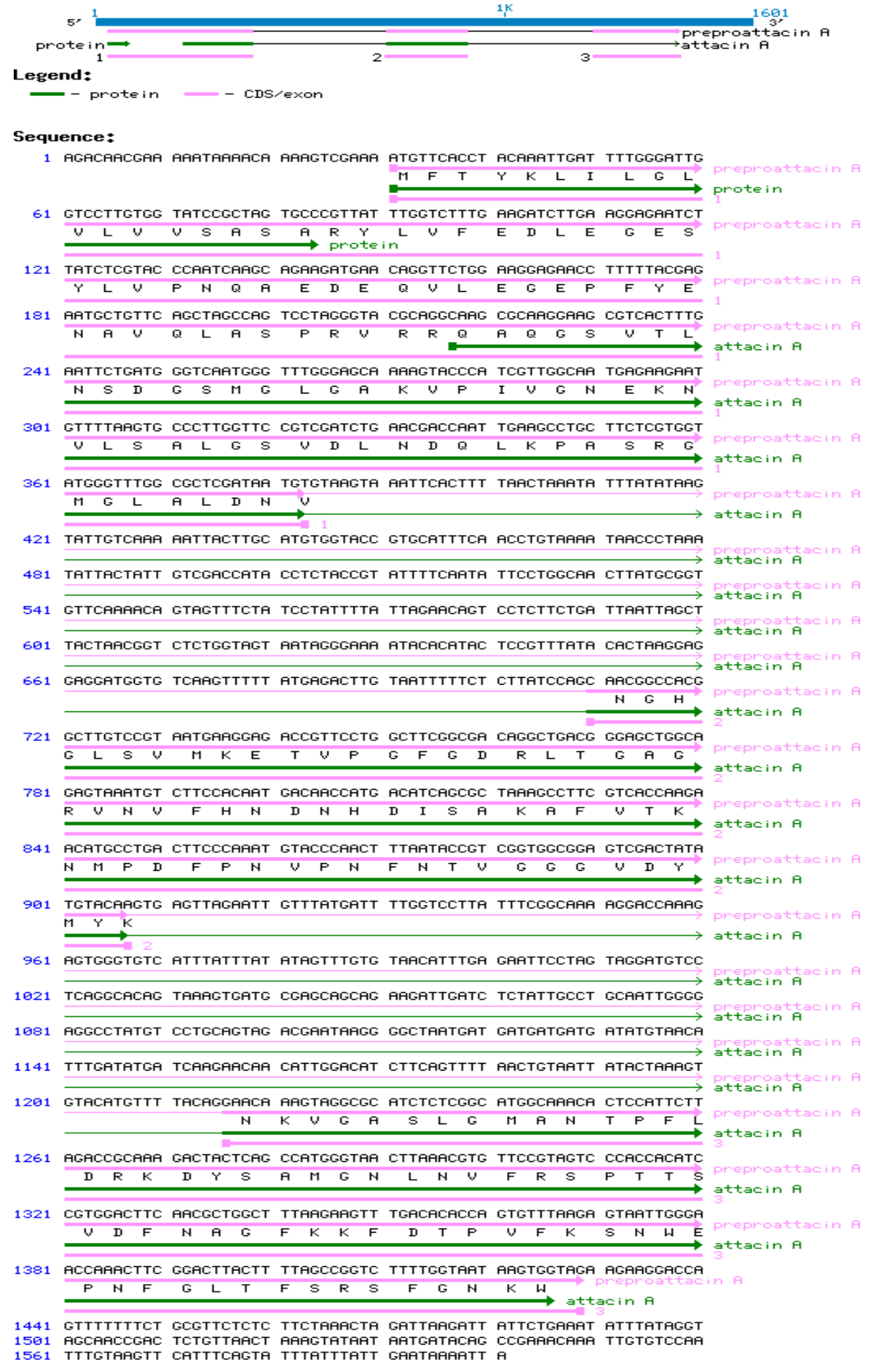

Figura 9 - Seqüência do gene atacina $A$ isolado de Trichoplusia ni. *

Fonte: Kang et al. (1996)

*O gene tem $1601 \mathrm{pb}$ e 2 introns; a região codificadora (CDS) tem 1399pb (preproatacina A) e o cDNA, 765pb (atacina A). A proteína atacina A é composta de 254 aminoácidos. GenBank NCBI (U46130). 


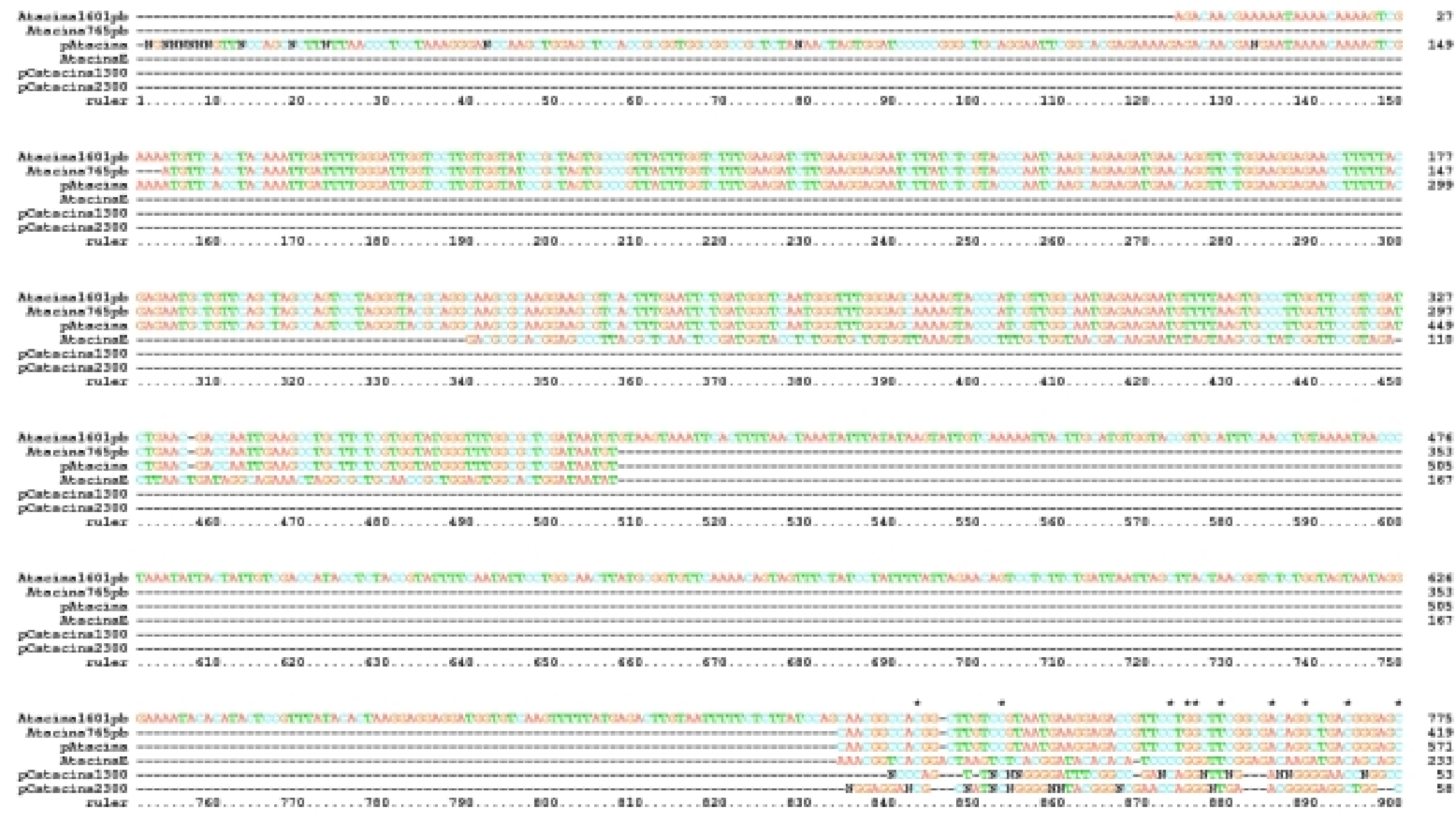

Figura 10 - Alinhamento das seqüências do gene atacina A de Trichoplusia ni utilizando o programa "Clustal X (1.81) Multiple Sequence Alignment":*

* Atacina1601pb (gene completo contendo os 2 introns), Atacina765pb (cDNA do gene), atacina E (de Hyalophora cecropia), pAtacina (cDNA clonado em pBlueScript), pCatacina 1300 (gene atacina A clonado em pCambia 1300) e pCatacina 2300 (gene atacina A clonado em pCambia 2300). 


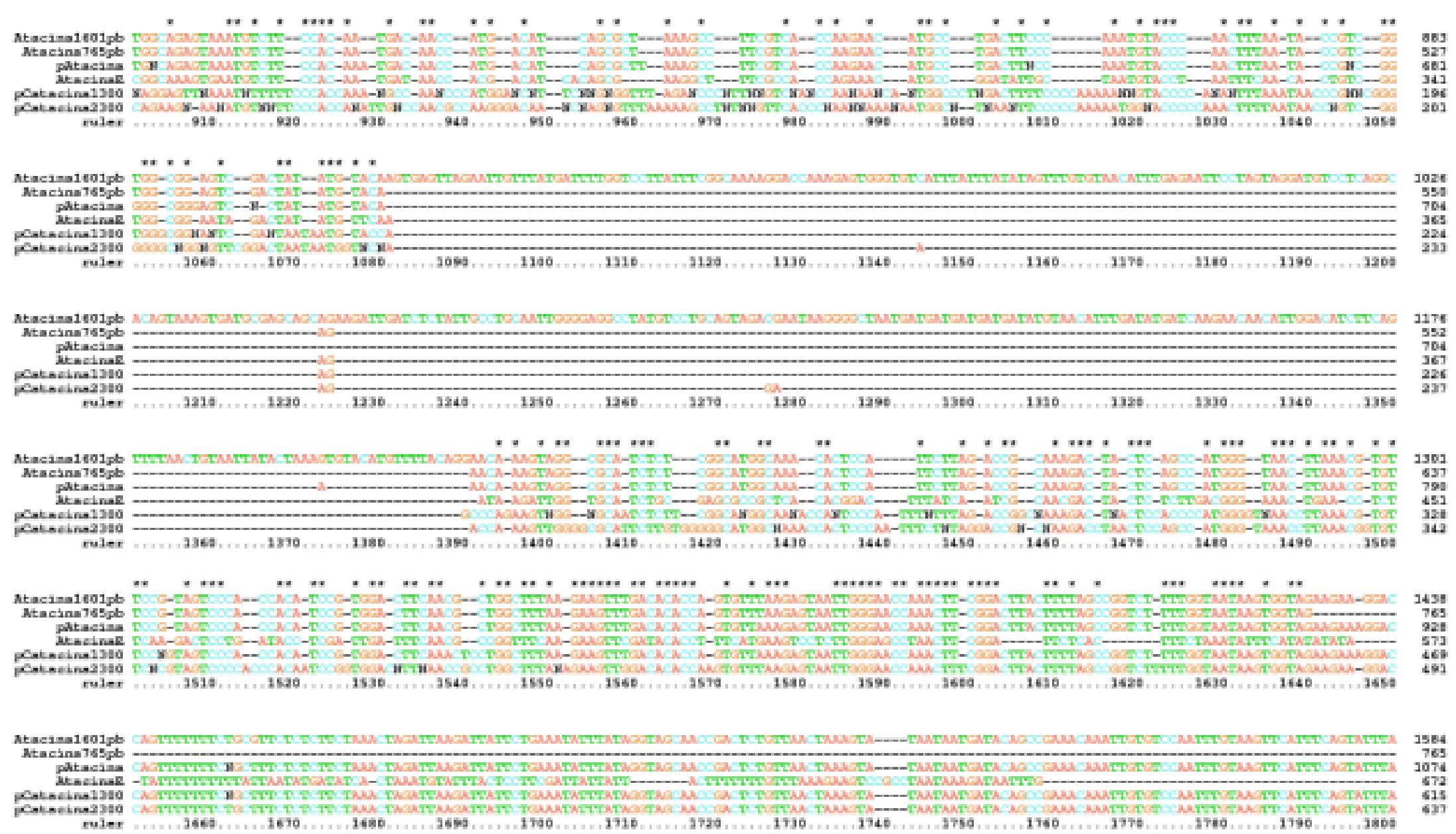

Figura 10 - Alinhamento das seqüências do gene atacina A de Trichoplusia ni utilizando o programa "Clustal X (1.81) Multiple Sequence Alignment":*

* Atacina1601pb (gene completo contendo os 2 introns), Atacina765pb (cDNA do gene), atacina E (de Hyalophora cecropia), pAtacina (cDNA clonado em pBlueScript), pCatacina 1300 (gene atacina A clonado em pCambia 1300) e pCatacina 2300 (gene atacina A clonado em pCambia 2300). 


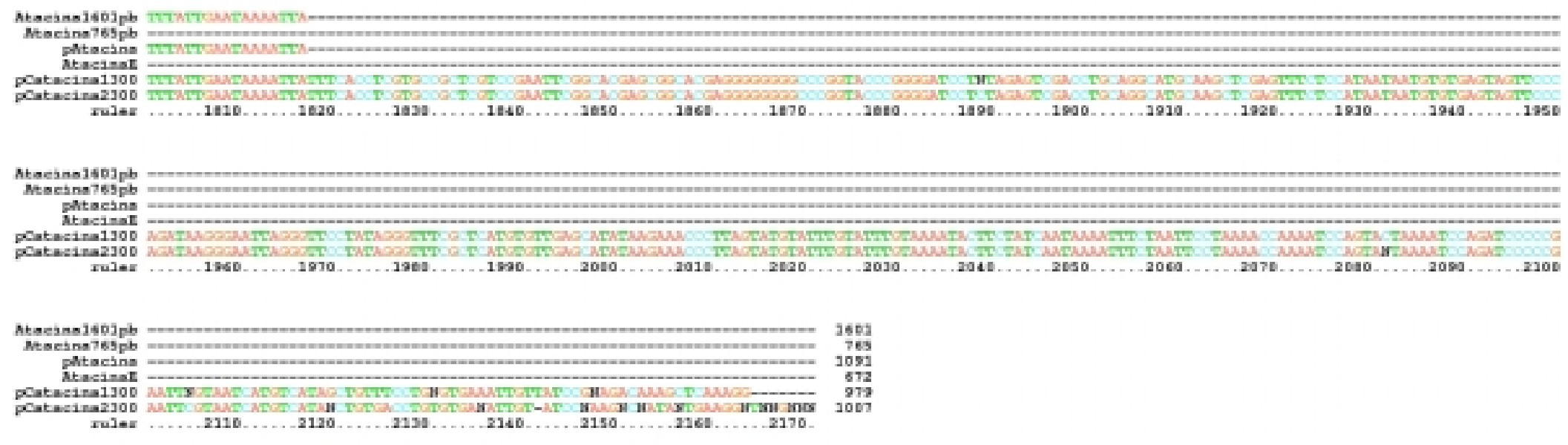

Figura 10 - Alinhamento das seqüências do gene atacina A de Trichoplusia ni utilizando o programa "Clustal X (1.81) Multiple Sequence Alignment":*

* Atacina1601pb (gene completo contendo os 2 introns), Atacina765pb (cDNA do gene), atacina $E$ (de Hyalophora cecropia), pAtacina (cDNA clonado em pBlueScript), pCatacina 1300 (gene atacina A clonado em pCambia 1300) e pCatacina 2300 (gene atacina A clonado em pCambia 2300). 
A- Mapa de restrição dos plasmídeos pAtacina e pFF19
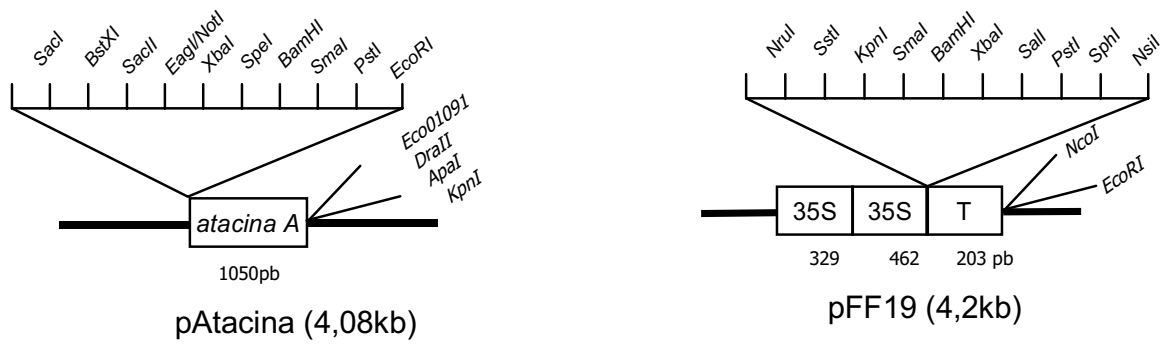

B- Digestão completa com Sacl e Kpnl e isolamento dos fragmentos
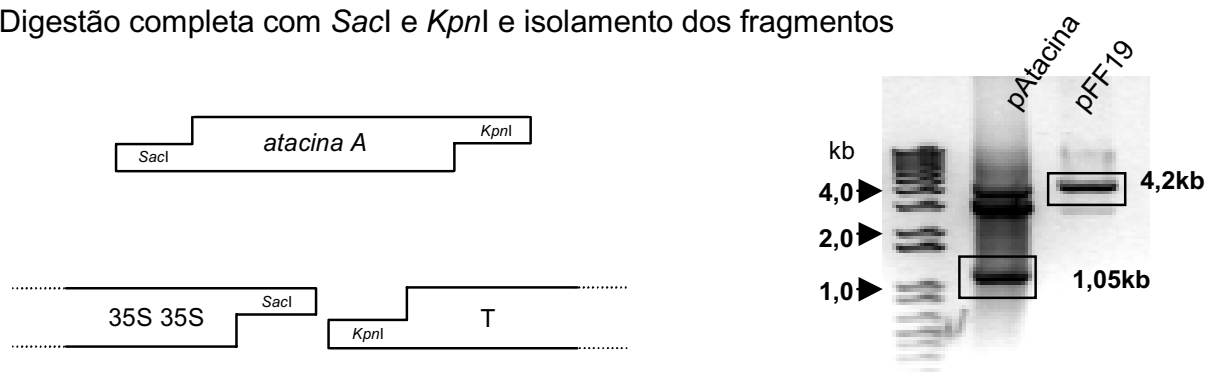

C- Ligação com T4 DNA ligase

D- "Screening" de bactérias por PCR
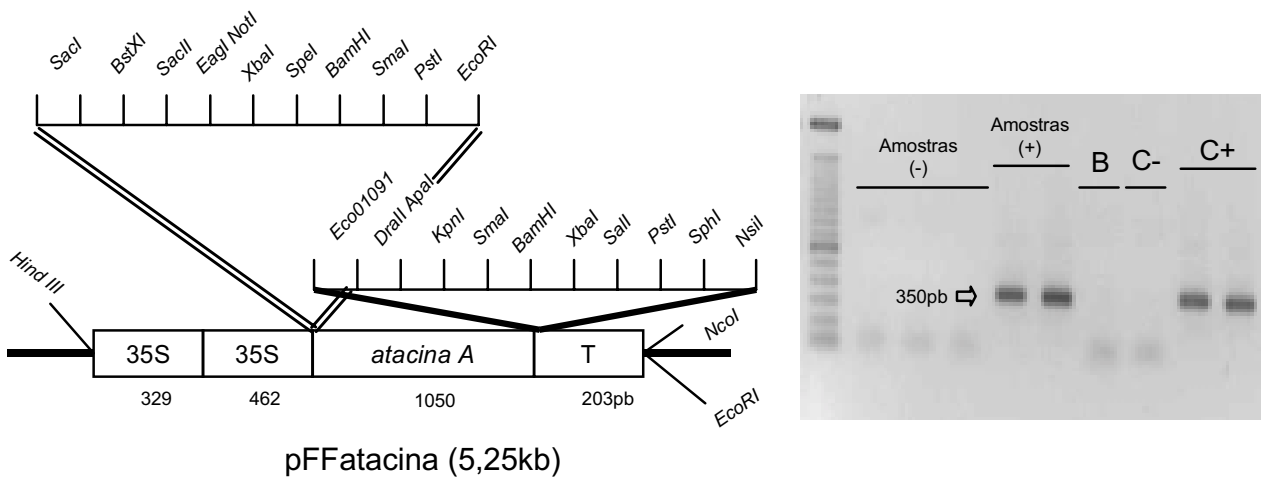

E- Vetor pFFatacina caracterizado pelas enzimas de restrição Xbal (à esquerda)e Xbal e HindllI (à direita)

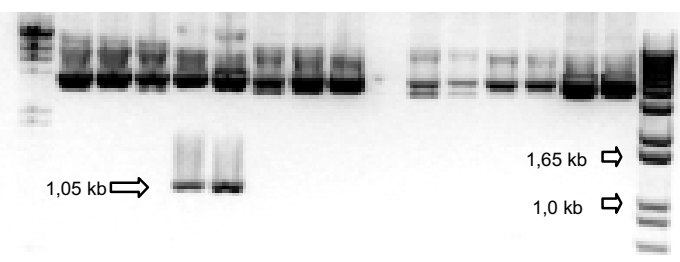

1

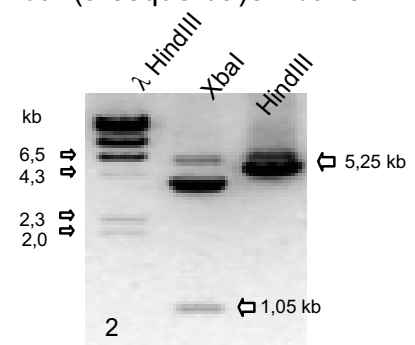

Figura 11 - Construção do vetor pFFatacina (Etapa 1).*

*A- Mapas de restrição dos plasmídeos pAtacina e pFF19; B- Digestão completa com Sacl e $K p n l$ e isolamento dos fragmentos; C- Ligação com T4 DNA ligase e o mapa de restrição do vetor pFFatacina; D- "Screening" de bactérias por PCR, utilizando "primers" para o gene atacina A; E- Restrição com Xbal (à esquerda) e Xbal e HindllI (à direita) para confirmação da construção. 
maracujá (co-bombardeamento com o vetor pBI426) até a construção do segundo vetor. O vetor pFFatacina está ilustrado no Anexo C.

\subsubsection{Etapa 2: Construção do vetor pCatacina 1300 e pCatacina 2300}

Apesar dos métodos de transformação que utilizam 2 ou mais vetores, processo chamado de co-transformação, serem empregados para gerar plantas transgênicas visando o piramidamento de genes (Chen et al., 1998b; Ye et al., 2000), é sabido que a integração de seqüências adicionais (supérfluas) do vetor aumenta quanto maior o número de vetores. Isso acontece quando se usa bombardeamento, eletroporação e também Agrobacterium tumefaciens.

Esta afirmativa é baseada em estudos recentes (Smith et al., 2001) pois até então havia consenso entre os pesquisadores que a região de transferência, quando se usa Agrobacterium, estaria restrita ao T-DNA. Entretanto, há trabalhos que comprovam a transferência de seqüências independentes da região do T-DNA inserida (Kononov et al., 1997; Wenck et al., 1997).

Sabendo da importância de reduzir seqüências adicionais, neste estudo foram construídos 2 vetores (pCatacina 1300 e pCatacina 2300), os quais carregam além do gene de interesse (atacina $A$ ) também os de seleção em plantas (nptll e hpt), que são os genes de resistência aos antibióticos canamicina/geneticina e higromicina, respectivamente para cada um dos vetores.

O gene atacina $A$ possui internamente vários sítios da enzima EcoRI (Figura 12A). O vetor pFFatacina foi digerido completamente com a enzima Hindlll, e testes de digestão parcial com a EcoRI foram realizados, a fim de definir a melhor concentração que permitia a sua liberação, com quantidade e integridade e também do cassete de expressão P35S35S-atacinaA-T35S, este com um tamanho em torno de 2,1kb (Figura 12B). 
A- Sítios de restrição de Hind III e EcoRI presentes no vetor pFFatacina

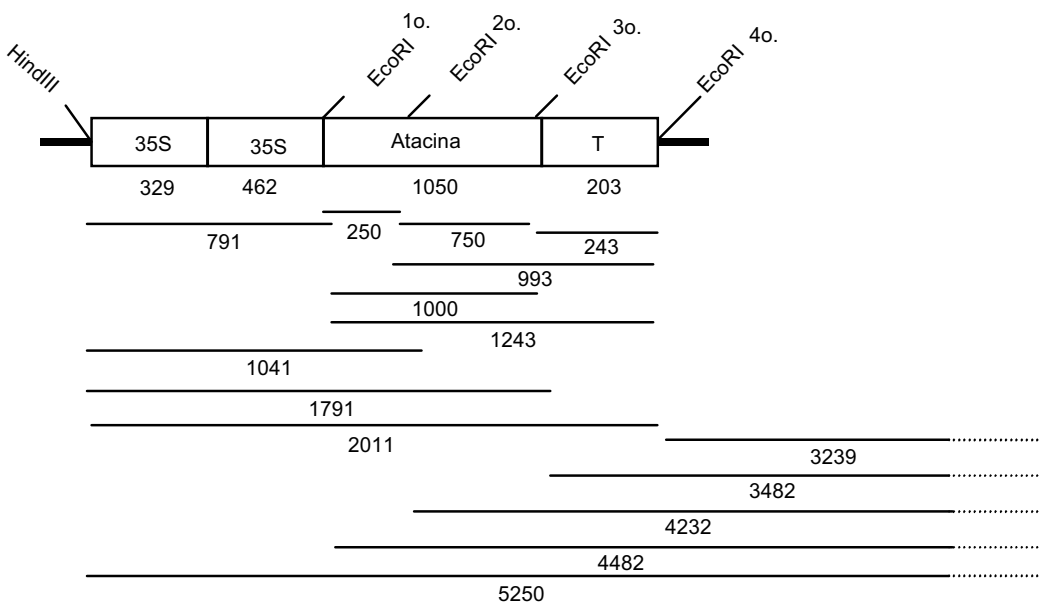

B- Digestão completa com Hindlll e parcial com EcoRI do vetor pFFatacina

1- Teste de digestão parcial com EcoRI

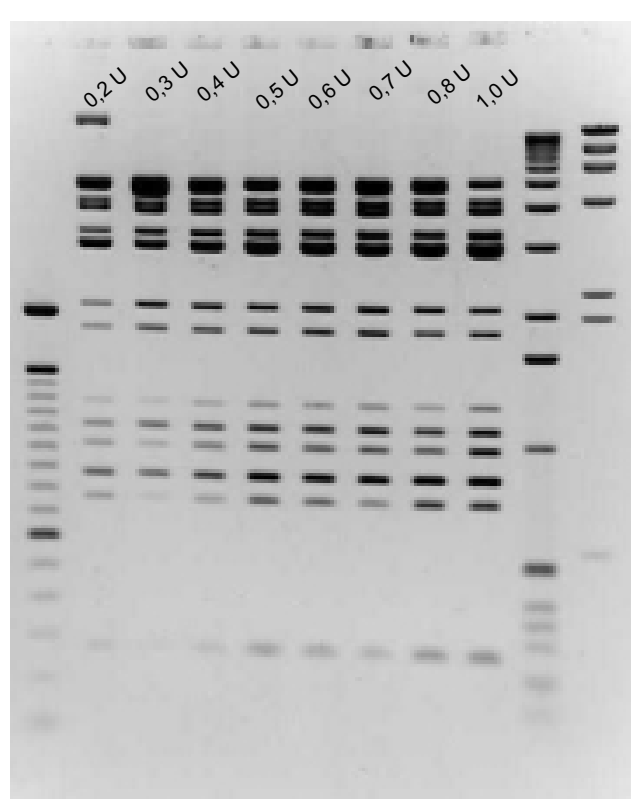

2- Digestão total e parcial

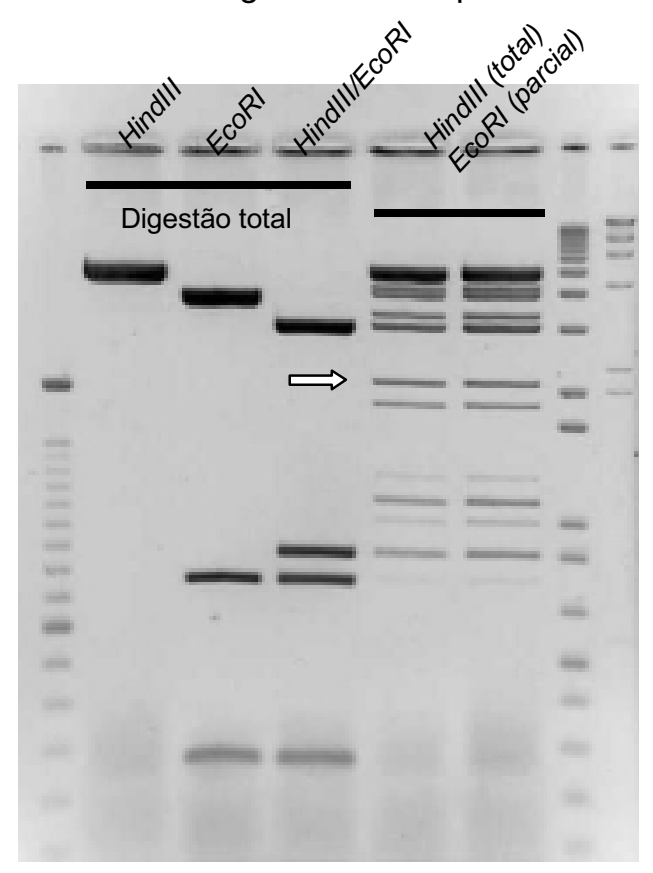

Figura 12 - Construção dos vetores pCatacina 1300 e pCatacina 2300 (Etapa 2).*

* A- sítios de restrição de Hindlll e EcoRI do vetor pFFatacina e os possíveis fragmentos gerados (pb) por digestão parcial com EcoRI; B- Digestão total com Hindlll e parcial com EcoRI, teste com $6 \mu \mathrm{g}$ de DNA plasmidial digeridos com 0,2 a 1,0 unidade $(U)$ de EcoRI por 20 min a $37^{\circ} \mathrm{C}$ (à esquerda), e caracterização do vetor pFFatacina (à direita, seta indica a banda isolada de $2,1 \mathrm{~kb}$ ). 
A digestão parcial foi eficiente para a liberação do fragmento de $2,1 \mathrm{~kb}$, em todos os tratamentos: $6,0 \mu \mathrm{g}$ de DNA plasmidial e nas concentrações de EcoRI utilizadas $\left(0,2 ; 0,3 ; 0,4 ; 0,5 ; 0,6 ; 0,7 ; 0,8\right.$ e 1,0 Unidade) por $20 \mathrm{~min}$ a $37^{\circ} \mathrm{C}$. Foi definida para essa concentração de DNA plasmidial, o tratamento com 0,4 U de EcoRI por 20 min (Figura 12B).

A amplificação por PCR confirmou a presença do gene atacina $A$ (Figura 13A), assim como a clonagem do cassete $(2,1 \mathrm{~kb})$, quando usou-se os "primers" para a região de clonagem (MCS) dos plasmídeos pCambia (Figura 13B-3). Os plasmídeos foram isolados e os clones foram primeiramente caracterizados com a enzima de restrição Xhol (Figura 13C), e em seguida, o mapa de restrição foi estabelecido com outras enzimas Hindlll, Xhol, HindllI + Xhol (Figura 14A e B). Os vetores foram chamados de pCatacina 1300 (higromicina + atacina A) e pCatacina 2300 (canamicina + atacina A).

A caracterização dos vetores pCatacina 1300 e pCatacina 2300 com as enzimas de restrição está na Figura 14 (A e B). Pôde se estabelecer o mapa de restrição de todos os vetores (Figura 15). Para verificar a ligação do cassete nos vetores, foi realizado o seqüenciamento utilizando-se os mesmos "primers" MCS (Figura 10). O seqüenciamento de $\sim 800 \mathrm{pb}$, para ambos os vetores, confirmou que clonagem foi adequada.

Os vetores pCatacina 1300 e pCatacina 2300 foram transferidos também para Agrobacterium tumefaciens cepas LBA4404 e EHA105. Por PCR, confirmou-se a presença do fragmento de $350 \mathrm{pb}$ referente ao gene atacina $A$ (Figura 16). Este sistema não foi usado no presente estudo, porém teve por objetivo tornar disponíveis linhagens de $A$. tumefaciens contendo esses vetores, visando futuros trabalhos de transformação indireta de plantas de maracujá.

Os vetores pCatacina 1300 e pCatacina 2300 estão representados nos Anexos D e E, respectivamente. 
A- Seleção de bactérias por PCR usando "primers" para o gene atacina $A$
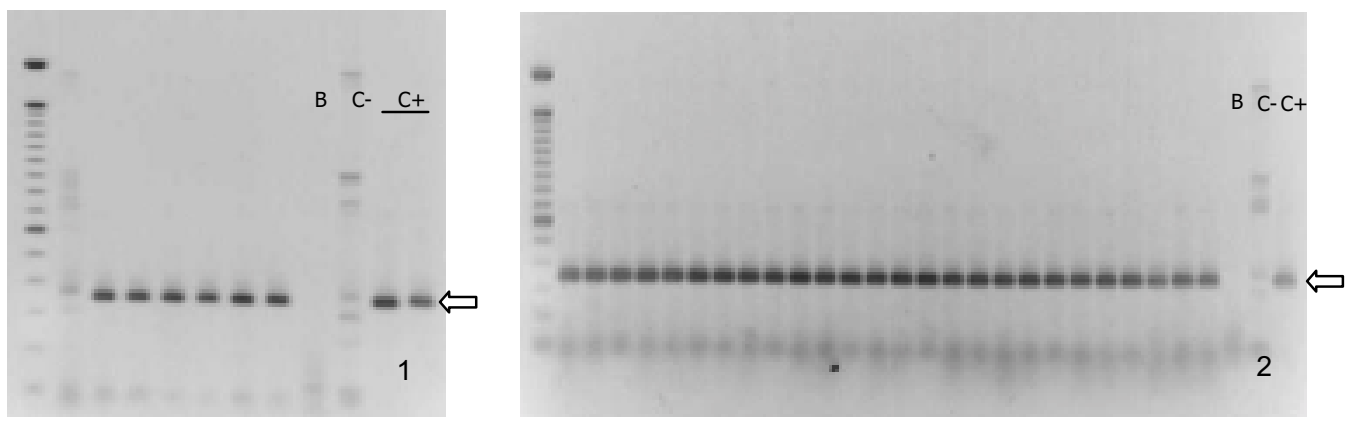

B- "Screening" de bactérias com "primer" da região MCS de pCambia
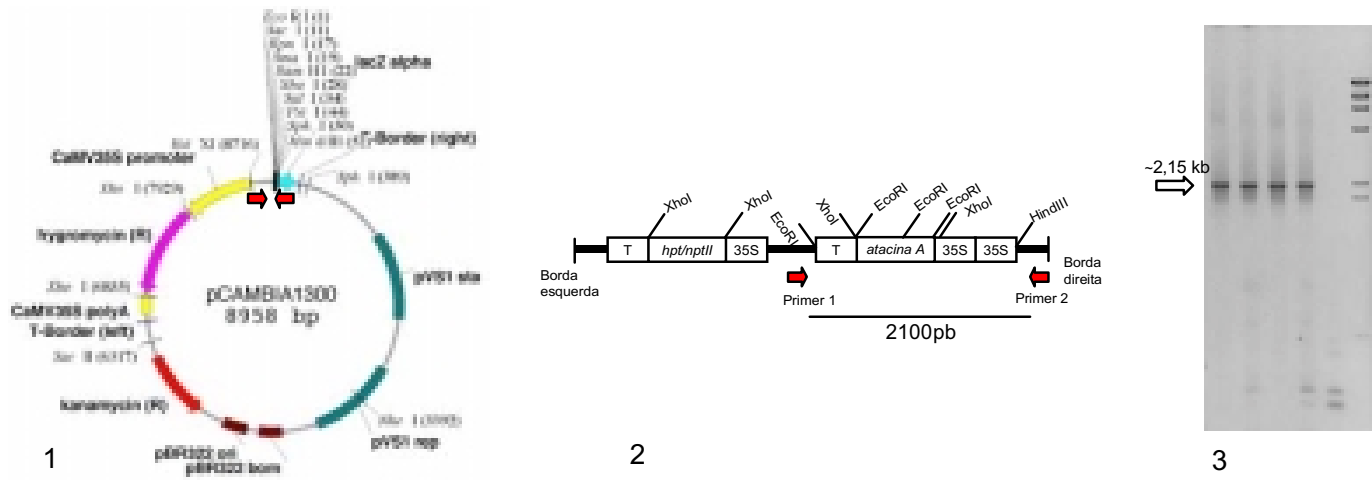

2

3

C- Seleção de plasmídeos com Xhol

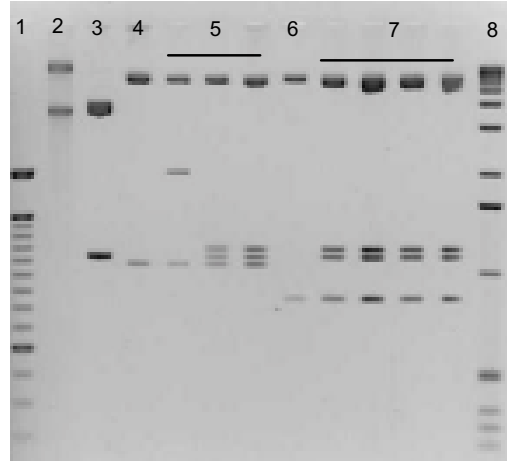
1- Marcador Ladder 100pb
Bandas esperadas:
2- pAtacina $(4,0 \mathrm{~kb})$
2- vetor íntegro
3- pFFatacina $(5,25 \mathrm{~kb})$
3- $4,0 / 1,12 \mathrm{~kb}$
4- pCambia $1300(9,0 \mathrm{~kb})$
4- $7,87 / 1,1 \mathrm{~kb}$
5- pCatacina $1300(11,0 \mathrm{~kb})$
$5-7,6 / 1,2 / 1,12 / 1,1 \mathrm{~kb}$
6- pCambia $2300(8,75 \mathrm{~kb})$
6- $7,86 / 0,88 \mathrm{~kb}$
7- pCatacina $2300(10,75 \mathrm{~kb}) \quad 7-7,6 / 1,2 / 1,12 / 0,88 \mathrm{~kb}$

8- Marcador Ladder $1 \mathrm{~kb}$

Figura 13 - Caracterização dos vetores pCatacina 1300 e pCatacina 2300.*

* A- "Screening" de bactérias por PCR, utilizando "primers" para o gene atacina $A$ (setas indicam o fragmento de 350pb) em vetores pCatacina 1300 (1) e pCatacina 2300 (2); B- "Screening" de bactérias por PCR, utilizando "primers" para região de clonagem de pCambia 1300 (1), o cassete de expressão de 2,1kb clonado (2) e o fragmento de $\sim 2,15 \mathrm{~kb}$ amplificado (3); C- Caracterização dos vetores pAtacina, pFFatacina, pCambia 1300, pCambia 2300, pCatacina 1300 e pCatacina 2300 com Xhol. 
A- Mapas de restrição de pCatacina 1300 e pCatacina 2300

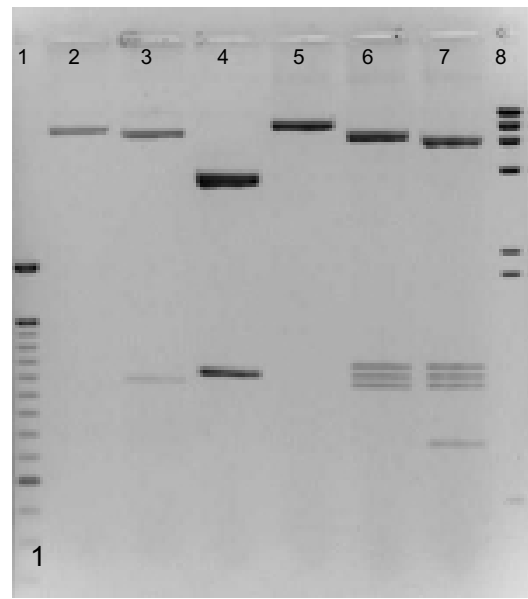

1- Marcador Ladder 100pb, 2- pCambia 1300 (Hind III), 3pCambia 1300 (Xhol), 4- pFFatacina (Xhol), 5- pCatacina 1300 (Hind III), 6- pCatacina 1300 (Xhol), 7- pCatacina 1300 (Hind III/Xhol), 8- Marcador $\lambda$ Hind III

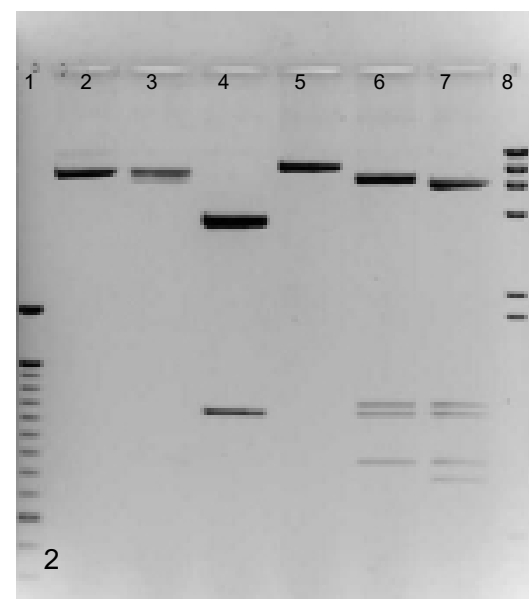

1- Marcador Ladder 100pb, 2- pCambia 2300 (Hind III), 3pCambia 2300 (EcoRl/HindIII), 4- pFFatacina (Xhol), 5pCatacina 2300 (Hind III), 6- pCatacina 2300 (Xhol), 7pCatacina 2300 (Hind III/Xhol), 8- Marcador $\lambda$ Hind III

B- Mapas dos vetores pFF, pCambia e pCatacina

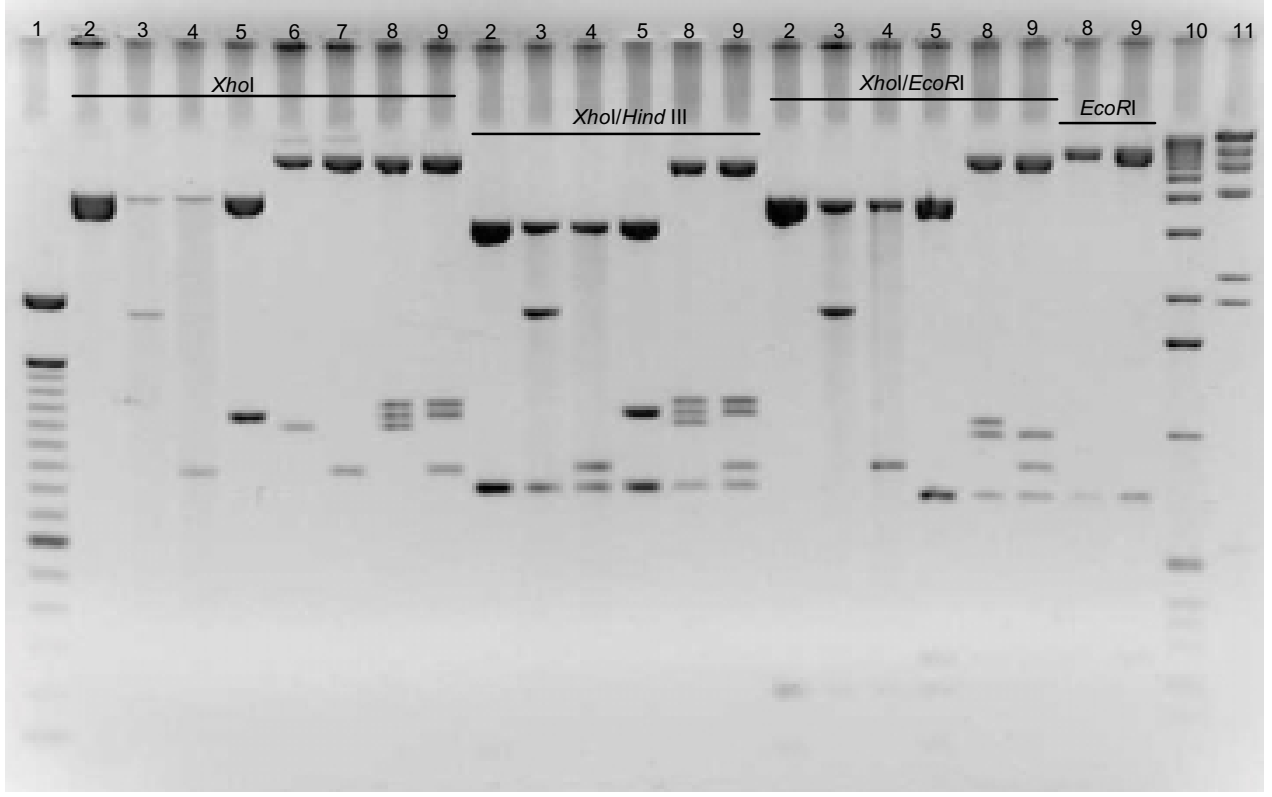

1- Marcador Ladder 100pb, 2- pFF19, 3- pFF19G, 4- pFF19K, 5- pFFatacina, 6- pCambia 1300, 7pCambia 2300, 8- pCatacina 1300, 9- pCatacina 2300, 10- Ladder 1 kb, 11- Marcador $\lambda$ Hind III

Figura 14 - Caracterização dos vetores por enzimas de restrição.

* A- pCatacina 1300 (1) e pCatacina 2300 (2), clivados com Hindll, Xhol e HindlII/Xhol. B- Vetores, pFF19, pFF19G, pFF19K, pFFatacina, pCambia 1300, pCambia 2300, pCatacina 1300 e pCatacina 2300 clivados com Xhol, Xhol/HindllI, Xhol/EcoRl e EcoRI. 
pFF19 (4,2kb)

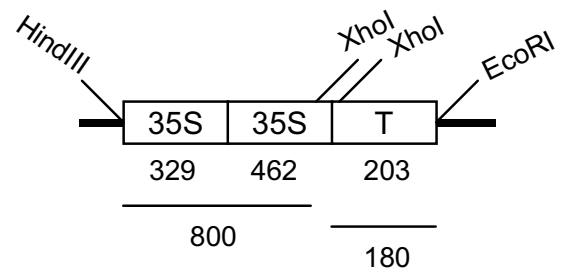

$\operatorname{pFF} 19 \mathrm{~K}(5,1 \mathrm{~kb})$
pFF19G $(6,0 \mathrm{~kb})$

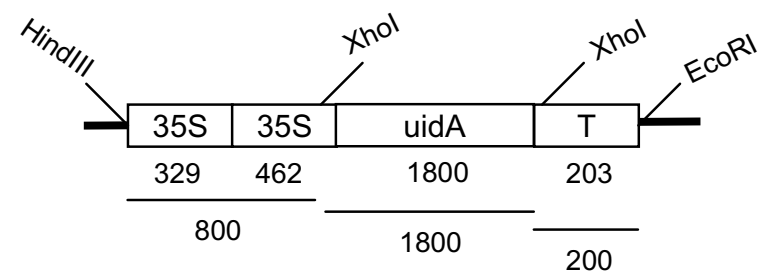

pFFatacina $(5,25 \mathrm{~kb})$

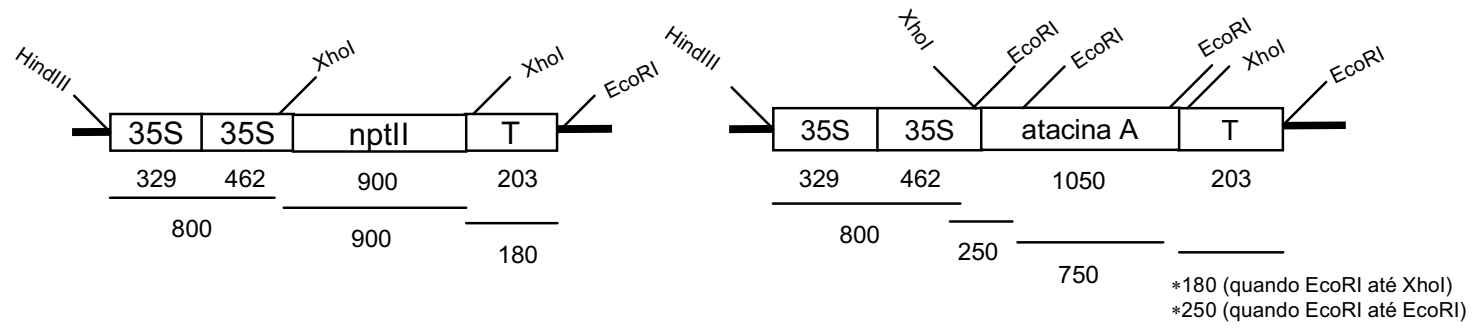

pCatacina $1300(11,0 \mathrm{~kb})$

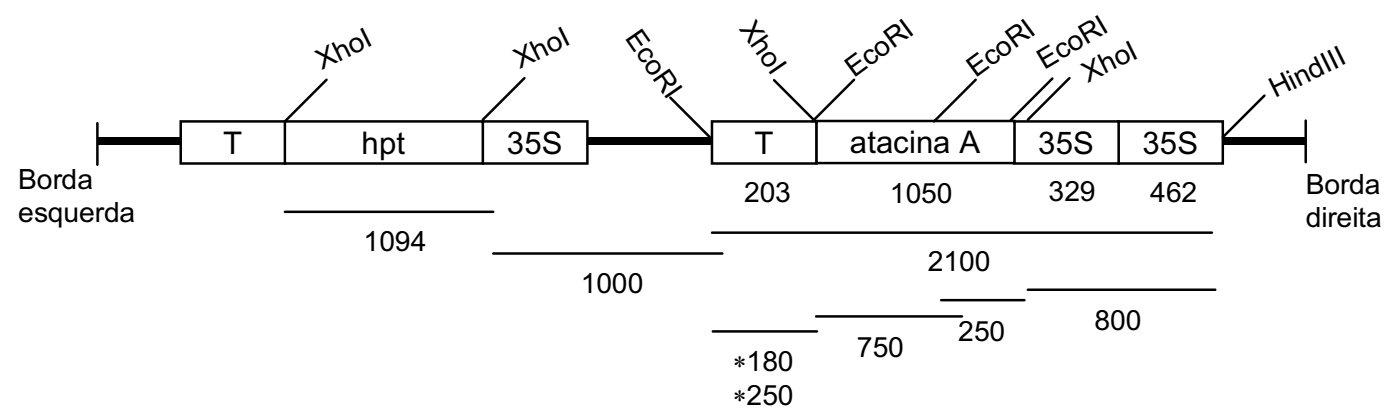

pCatacina $2300(10,75 \mathrm{~kb})$

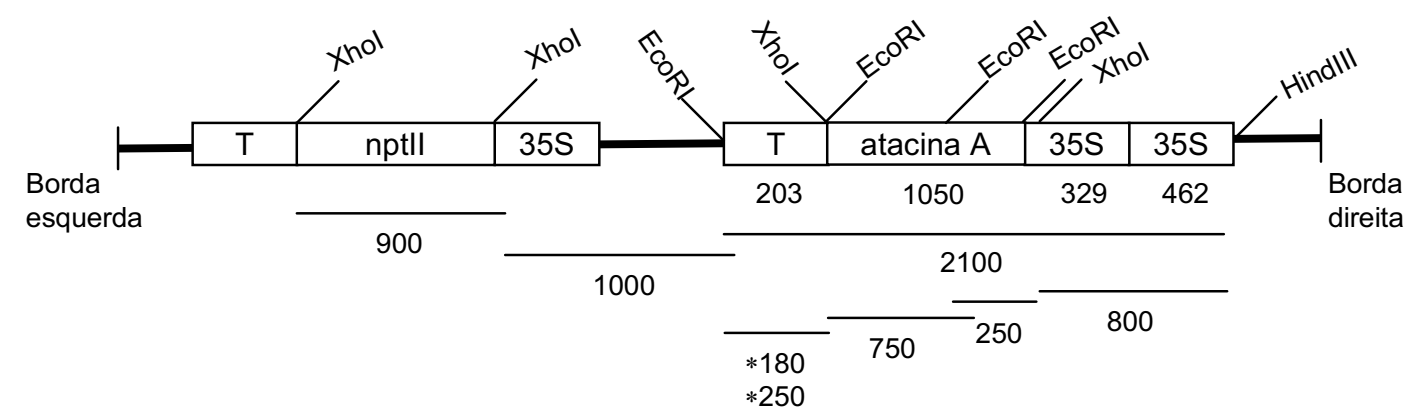

Figura 15 - Mapas de restrição dos vetores, obtidos por clivagem com EcoRI, Xhol, HindIII, e combinação entre elas (em pb). 

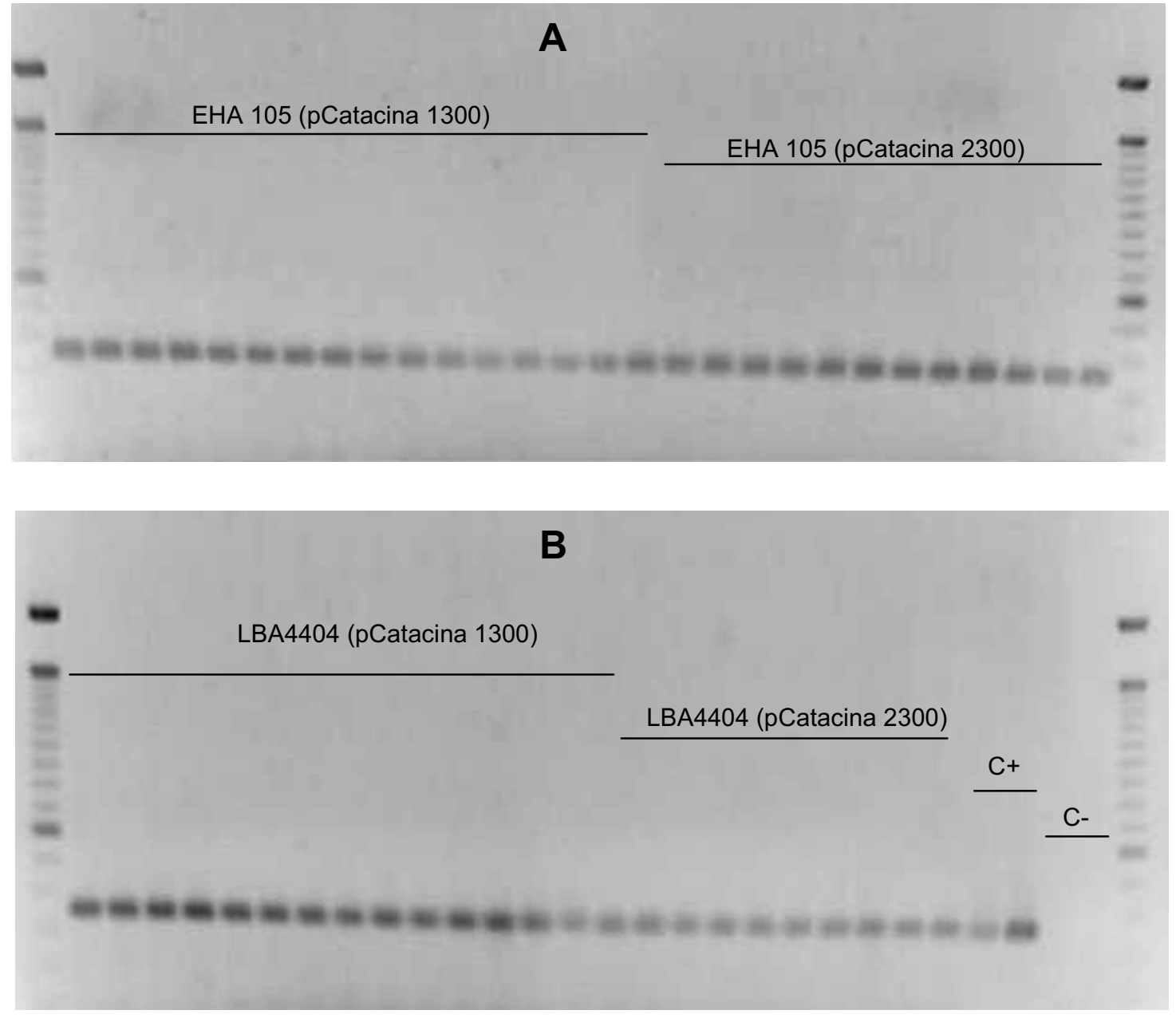

Figura 16 - Caracterização da transferência dos vetores pCatacina 1300 e pCatacina 2300 para Agrobacterium tumefaciens: estirpes EHA105 (A) e LBA 4404 (B).*

* C+: pCatacina 1300 e pCatacina 2300. C-: pCambia 1300 e pCambia 2300. "Screening" de bactérias por PCR, utilizando "primers" para o gene atacina $A(350 \mathrm{pb})$. 


\subsection{Transformação por biobalística}

Bombardeamento de partículas é o método mais amplamente usado para plantas que não são suscetíveis à transformação via Agrobacterium, tais como a maioria das monocotiledôneas e algumas dicotiledôneas (Christou, 1995).

Recentemente, plantas como a batata (Romano et al., 2001) e abacaxi (Sripaoraya et al., 2001) foram efetivamente transformadas por bombardeamento de partículas, com freqüência de transformação de $20 \%$ em batata, freqüência superior ao obtido via Agrobacterium (14\%). Para monocotiledôneas, como milho e trigo, freqüências de transformação de 45 e $20 \%$, respectivamente, foram obtidas por biolística, quando substituiu-se o marcador seletivo herbicida (bar) por fosfomanose isomerase (pmi), enzima que quebra o açúcar manose do meio de cultura para utilização como fonte de carbono (Wright et al., 2001; Reed et al., 2001).

O desenvolvimento de protocolos eficientes de bombardeamento de partículas permite a integração e expressão de vários genes ao mesmo tempo, utilizando-se apenas um único marcador seletivo. A principal vantagem é rapidez na obtenção dos transgênicos.

\subsubsection{Otimização dos parâmetros para transformação do maracujazeiro por biobalística analisada pela expressão transiente de uidA}

\subsubsection{Parâmetros biológicos}

Neste estudo, foram empregados explantes foliares e cotiledonares com idades de até 10 dias de cultivo, e calos de segmentos entrenodais e de hipocótilo cortados transversalmente $(2 \mathrm{~mm})$ com idades de 3 a 30 dias de cultivo. 
Os explantes, disco foliar e cotiledonar, apresentaram pontos azuis bem definidos nas suas superfícies adaxiais (Figuras 17 e 18). As análises histológicas mostraram reação positiva para GUS nas células da epiderme e subepiderme (Figura 18G a M), ou seja, nos mesmos tipos celulares dos quais se originam os meristemóides e que dão origem às gemas adventícias (Appezzato-da-Gloria et al., 1999). No entanto, a expressão foi bem menor em relação àquela observada nos calos oriundos de segmentos entrenodais ou hipocotiledonares e, na sua maioria, os pontos apareceram espalhados pelo explante.

A freqüência e o nível de expressão de GUS em calos de até 10 dias foi intensa, com pontos azuis bem definidos em quase toda a superfície do explante bombardeado (Figuras 17C e D). Os cortes histológicos mostraram a profundidade em que o gene uidA está sendo expresso (Figura 18).

Para plantas que possuem sistema de regeneração originário de células mais profundas do tecido, como observado em Brassica (Mukhopadhyay et al., 1992), a biobalística seria uma estratégia promissora, já que parâmetros podem ser alterados para que o gene alcance um determinado local e uma vez que a agrobactéria não atinge essa região.

Para maracujá, a região meristemática está localizada nas camadas superficiais do explante entrenodal ou hipocotiledonar (Figuras 18B e C). Isso é considerado uma vantagem para a transformação genética tanto por métodos via Agrobacterium como diretos, pela facilidade com que o plasmídeo possa atingir as células alvo e o gene de interesse se integre ao núcleo.

O segmento cultivado por somente 10 dias apresentou formação de calos, não havendo diferenciação aparente. Portanto, se trata de um excelente material para bombardeamento, pois provavelmente não haverá o aparecimento de indivíduos transgênicos quiméricos. Por outro lado, calos de 20 a 30 dias já apresentam diferenciação foliar, o que facilitaria o surgimento de plantas quiméricas (Figura 17E). 


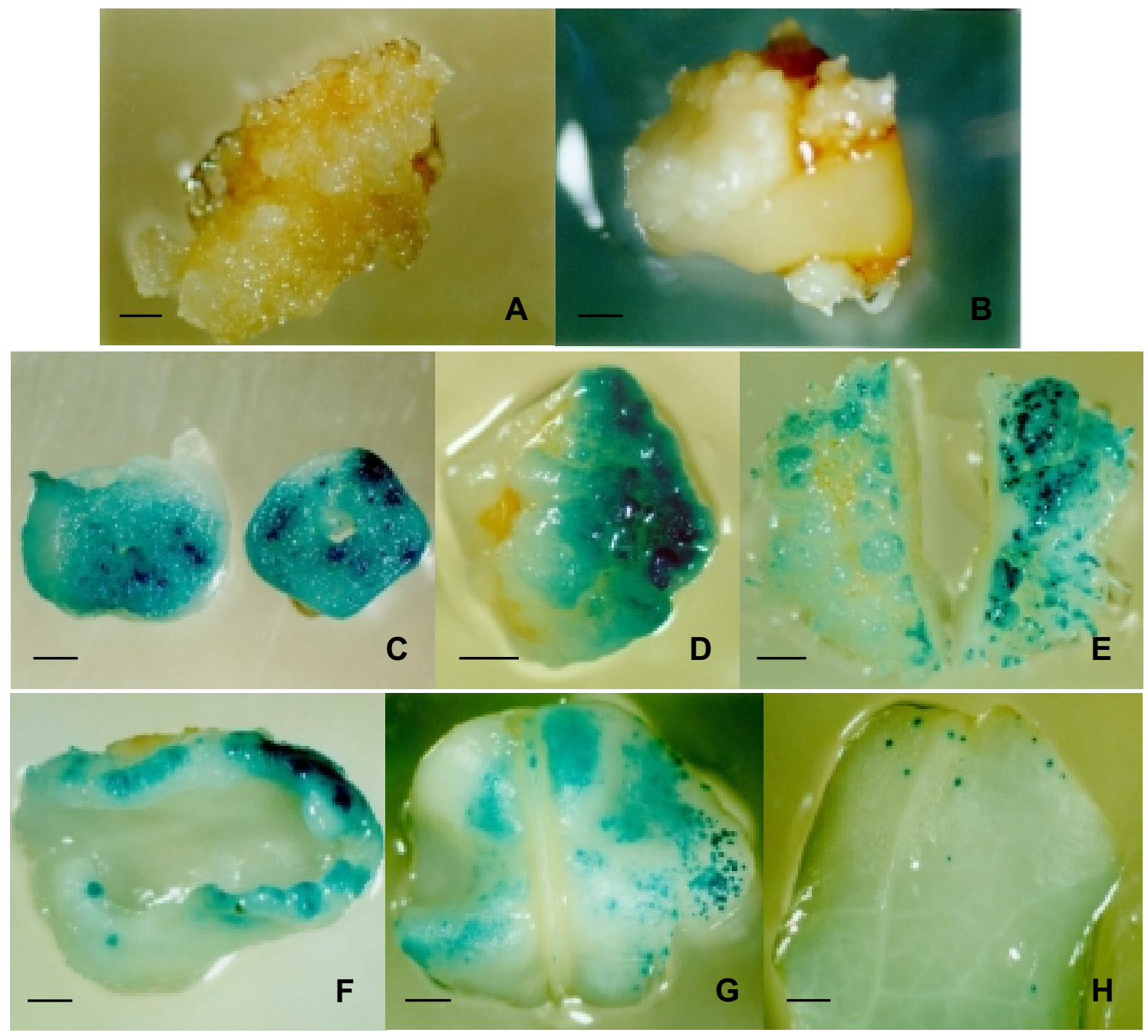

Figura 17 - Expressão transiente de GUS em diferentes explantes e idades de cultura de $P$. edulis Sims f. flavicarpa Deg. *

* Controles negativos (A-10 e B- 20 dias). Calos (C - 6, D - 10 e E - 25 dias), cotilédone ( $F-6$ dias), discos foliares ( $G-1$ e H -6 dias). Vetores pBI426 (D, F, G e H) e pFF19G (C e E). Parâmetros físicos: 1200 psi/9,5 cm de distância do alvo (C, D e E); 800 psi $/ 6,5 \mathrm{~cm}$ de distância do alvo $(F, G$ e H). Barras = $760 \mu \mathrm{m}(\mathrm{A}), 450 \mu \mathrm{m}$ (B), $620 \mu \mathrm{m}$ (C), $690 \mu \mathrm{m}$ (D e E), $760 \mu \mathrm{m}$ (F) e $870 \mu \mathrm{m}$ (G e H). 


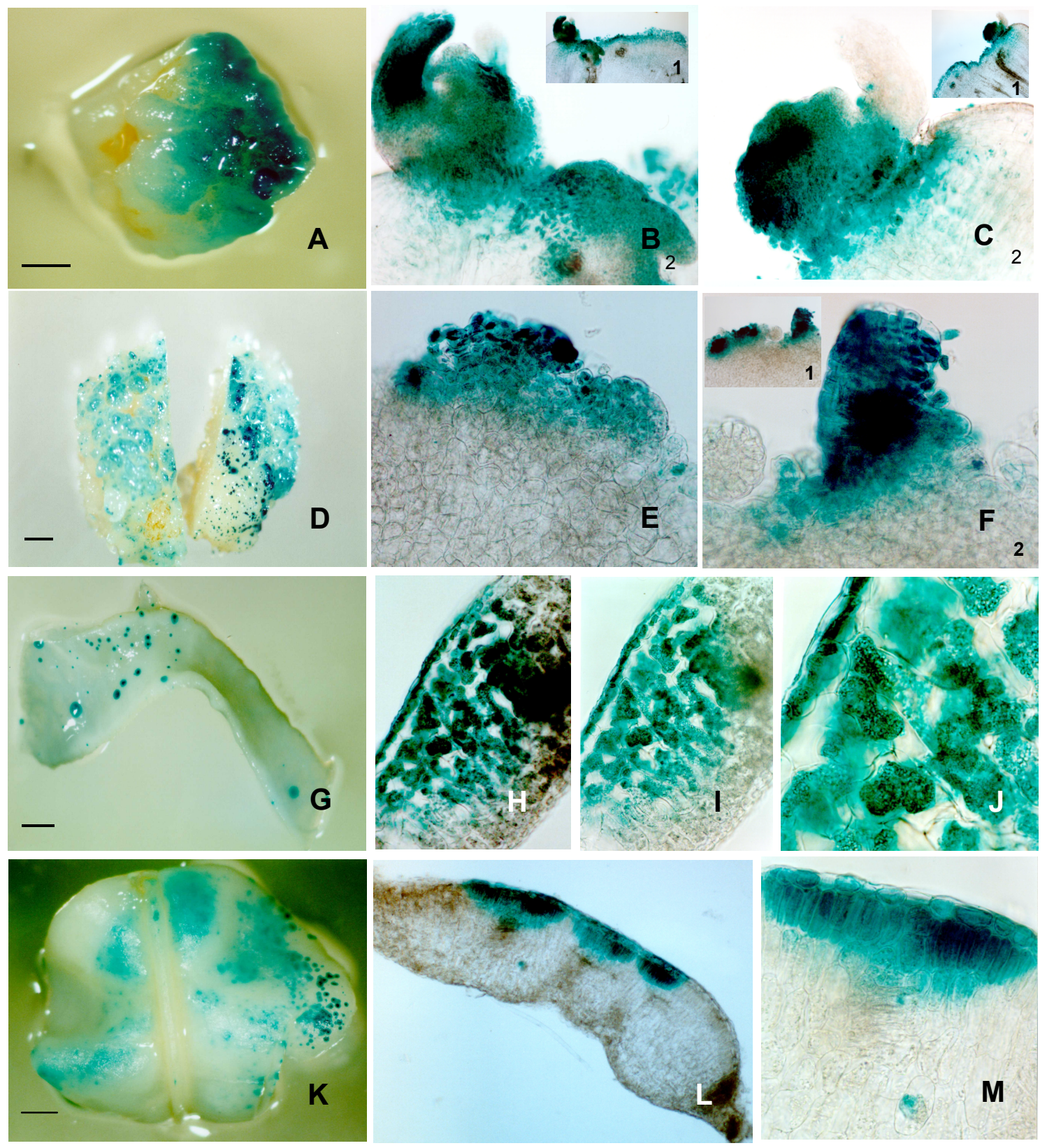

Figura 18 - Expressão transiente de GUS, utilizando os vetores pBI426 e pFF19G.*

* A- calo de 10 dias transformado com pBI426 (barra $=690 \mu \mathrm{m}$ ); B e C- detalhes da seção longitudinal de gemas axilares do calo $A$ [aumento 4x (B1 e C1), 10x (B2 e C2)]; D- calo de 20 dias transformado com pFF19G (barra $=690 \mu \mathrm{m}$ ); $\mathrm{E}$ e F- corte histológico do calo $\mathrm{B}$ [aumento 10x (E), 4x (F1) e 20x (F2)]; G- cotilédone cultivado por 3 dias e bombardeado com pBI426 (barra $=870 \mu \mathrm{m}$ ); $\mathrm{H}, \mathrm{I}$ e J- corte transversal do material G [aumento 10x $(\mathrm{H}), 20 x(\mathrm{I})$ e 40x (J)]; K- disco foliar cultivado por 3 dias e bombardeado com pBI426 (barra $=870 \mu \mathrm{m}$ ); L e M- seção transversal de $\mathrm{K}$ [aumento $4 \mathrm{x}(\mathrm{L})$ e 20x (M)]. Condições de bombardeamento: $5 \mu \mathrm{g}$ de DNA plasmidial, 800 psi $/ 6,5 \mathrm{~cm}$ ou 1200 psi/9,5 cm de distância do alvo, $65 \mathrm{~mm} \mathrm{Hg}$ de gás Hélio. 
A uniformidade da superfície-alvo, a presença de células desdiferenciadas e altos níveis de expressão transiente do gene repórter fizeram com que calos de até 10 dias fossem utilizados para os experimentos de otimização dos parâmetros físicos. Apesar de pouca expressão do gene na superfície dos discos foliares, estes também foram utilizados. O tecido cotiledonar não foi empregado por se ter utilizado uma popluação (70 indivíduos) propagada por microestaquia.

A utilização do vetor pB|426 não conferiu maior aumento de expressão de GUS (uidA) em comparação a pFF19G (Figura 17 e 18). Outros trabalhos mostram que a presença de uma seqüência "leader" AMV não traduzível do pBI426 aumentou a expressão de genes em protoplastos de ervilha (Hobbs et al., 1990), em coníferas (Charest et al., 1993), banana (Sági et al., 1995b) e maçã (Ko et al., 2000). Segundo Jobling \& Gehrke (1987), a superexpressão é dada pela seqüência AMV que aumenta a eficiência na tradução de mensageiros quiméricos, por haver grande quantidade de transcritos de RNAm. A expressão intensa aqui relatada deve ter sido favorecida pela presença de $35 S$ duplicado nos 2 vetores utilizados. O vetor pFF19G foi construído para ter máxima expressão do gene repórter (enzima $\beta$-glucuronidase) pela presença de um promotor 35 S com "enhancer" duplicado (Timmermans et al., 1990).

\subsubsection{2- Parâmetros físicos}

A eficiência de transformação é dependente da interação de vários parâmetros físicos: a velocidade com que as micropartículas atingem o tecidoalvo, que por sua vez é função de sua força de aceleração, da distância de vôo destas partículas e da desaceleração provocada pelo atrito durante o tempo de vôo (Sanford et al., 1991; 1993; Christou, 1995).

Foram avaliadas 3 pressões de gás Hélio (800, 1000 e 1200 psi) em combinação com 3 distâncias de vôo das micropartículas até o alvo (6,5, 9,5 e 
12,5 cm) (Tabela 7). A pressão de ruptura determina a energia da onda de choque e, por conseguinte, a velocidade das micropartículas.

A presença de pontos azuis foi observada em todos os tratamentos. As maiores freqüências de explantes expressando GUS foram obtidas empregando-se as combinações 800/6,5, 1000/9,5 e 1200/12,5 (psi/cm) (Tabela 7; Figura 17 e 18). Altas pressões combinadas com distâncias menores de vôo das micropartículas resultaram em intenso dano ao tecido e, conseqüentemente, baixa freqüência de explantes expressando o gene repórter.

Esses resultados estão de acordo com os encontrados por Quecini (1999), em que calos de estilosantes bombardeados a pressões/distância do alvo de $1300 / 5,0 \mathrm{~cm}$ e $1600 / 5,0 \mathrm{~cm}$ sofreram danos. Segundo Sanford et al (1993), as pressões de gás Hélio próximas a 1000 psi são ótimas ou quase ótimas para a maioria das aplicações, pois pressões menores não provocam aceleração suficiente para que as micropartículas penetrem nas células e atinjam o núcleo, enquanto pressões superiores causam danos irrecuperáveis ao tecido. No estudo realizado por Quecini (1999) o ideal foram pressões em torno de 1300 psi e distâncias de $12,5 \mathrm{~cm}$ de vôo das micropartículas utilizando calos organogênicos de 30 dias.

Assim, pressões de gás Hélio de 800 a 1000 psi e distâncias de 6,5 a 9,5 cm de vôo das micropartículas até o alvo foram mais favoráveis para a transformação de calos organogênicos, disco foliar e cotiledonar de maracujá.

Apesar de alguns estudos relatarem a influência desses parâmetros na eficiência de transformação, Sanford et al. (1993) recomendam distâncias de 6 a $12 \mathrm{~mm}$ entre a membrana de ruptura e o macrocarreador, como sendo adequadas para uma transferência eficiente de energia para as micropartículas, com variação mínima, para diversas espécies vegetais. Quecini (1999) relata como sendo ideais distâncias de 10 a $20 \mathrm{~mm}$ para ambos os parâmetros descritos na transformação de estilosantes. Os parâmetros utilizados para as monocotiledôneas milho e trigo são de $8 \mathrm{~mm}$ entre o disco de ruptura e o 
macrocarreador e $10 \mathrm{~mm}$ entre o macrocarreador e a tela de retenção (Wright et al., 2001). A distância entre macrocarreador e a tela de retenção parece ter pouco efeito. Recomenda-se a utilização de 6 a $11 \mathrm{~mm}$ de distância.

Tabela 7. Expressão transiente de GUS (número de pontos azuis) em função da pressão de gás Hélio (psi) e distância de vôo das micropartículas até o alvo $(\mathrm{cm})$ em calos e discos foliares de $P$. edulis f. flavicarpa.

\begin{tabular}{cccc}
\hline \multirow{2}{*}{$\begin{array}{c}\text { Pressão de gás } \\
\text { (psi) }\end{array}$} & $\begin{array}{c}\text { Eistância } \\
(\mathrm{cm})\end{array}$ & Calo & Disco foliar \\
\cline { 2 - 4 } 1200 & 6,5 & $5 \pm 3$ & $3 \pm 2$ \\
& 9,5 & $35 \pm 5$ & $12 \pm 6$ \\
12,5 & $42 \pm 8$ & $28 \pm 15$ \\
1000 & 6,5 & $27 \pm 4$ & $15 \pm 8$ \\
& 9,5 & $>50 \pm 15^{\text {a* }}$ & $>50 \pm 20$ \\
& 12,5 & $35 \pm 10$ & $16 \pm 7$ \\
& 6,5 & $>50 \pm 13$ & $30 \pm 25$ \\
& 9,5 & $25 \pm 9$ & $9 \pm 4$ \\
& 12,5 & $9 \pm 3$ & $7 \pm 4$ \\
\hline
\end{tabular}

a $>50$ corresponde a 51 pontos até superfície totalmente corada de azul.

Os valores correspondem à média de amostras selecionadas de 7 e 4 bombardeamentos para calo e disco foliar, respectivamente. As médias estão acompanhadas do respectivo desvio padrão. Condições de bombardeamento: $65 \mathrm{mmHg}$ de vácuo na câmara, $5 \mu \mathrm{g}$ de DNA plasmidial, calos de 6 dias e disco foliar de 3 dias. 


\subsection{Transformação de maracujazeiro com o gene atacina $A$}

\subsubsection{Co-bombardeamento utilizando 2 plasmídeos}

Os explantes, disco foliar de 3 dias e calos oriundos de segmentos entrenodais de até 10 dias, foram co-bombardeados e selecionados em 50 $\mathrm{mg} / \mathrm{L}$ de canamicina, uma semana após o bombardeamento.

Logo após o bombardeamento, os explantes em meio MSB(A) permaneceram no escuro por 1 dia. Essa condição parece ter importância para a recuperação dos explantes do estresse físico ocasionado pelos microprojéteis. Ainda nesse meio, os explantes permaneceram por mais 7 dias na luz para então serem transferidos ao meio seletivo, MSB(A)K.

$O$ processo de regeneração de plantas transformadas pode ser observado na Figura 19 (A-C): cultivo dos explantes em meio seletivo, detalhe dos brotos (A), gemas separadas do explante para melhor seleção (B) e regeneração de plantas $(C)$.

Os explantes não transformados (controles) foram subcultivados em meio $\operatorname{MSB}(A)$, sem antibiótico. Enquanto o controle apresentou brotos já na primeira semana, antes do subcultivo, os explantes bombardeados desenvolveram brotação somente na segunda semana, em freqüência bem menor (Tabela 8).

É consenso que a eficiência de regeneração é crítica para a obtenção de transformação. Neste estudo, a eficiência de regeneração de brotos reduziu muito após o bombardeamento dos discos foliares $(16,67 \%)$ e dos calos $(3,55 \%)$ em comparação com os controles, ou seja, 80 e $20 \%$, respectivamente (Tabela 8). Essa baixa eficiência provavelmente deve estar relacionada à ação do agente seletivo canamicina que inibe a regeneração. É sabido que uma das grandes desvantagens da utilização de genes de resistência a antibiótico/herbicida é que as células, diretamente ou indiretamente, estão 
sujeitas a processos necróticos associados com componentes tóxicos e inibidores de crescimento que são lançados ao redor das células transformadas (Hoffmann \& Vieira, 2000). Outra razão, é a baixa regeneração induzida pelo antibiótico.

Os brotos oriundos dos explantes que passaram pela seleção também apresentaram dificuldades para sofrer elongação da parte aérea $\mathrm{e}$ enraizamento, principalmente, pela via indireta de organogênese, em que somente duas plantas foram recuperadas.

Dificuldades em enraizar plantas transformadas têm sido relatadas em maracujá quando selecionadas em meio com canamicina (Silva, 1998), em Eucalyptus (Ho et al., 1998) e Citrus (Peña et al., 1995a, 1995b).

Debergh \& Read (1991) atribuem à longa permanência dos explantes em presença de citocininas durante o processo de regeneração a dificuldade de enraizamento; portanto, aconselha-se usar subcultivos sucessivos em meios sem reguladores ou em concentrações reduzidas $(<0,5 \mathrm{mg} / \mathrm{L})$ para diminuir o efeito residual e inibitório de citocininas no enraizamento. Em maracujazeiro, ocorre enraizamento em $1 / 2$ MS sem regulador de crescimento (Dornelas \& Vieira, 1994).

Em Citrus a dificuldade na fase de enraizamento foi contornada pela técnica de microenxertia de ápices caulinares oriundos de plantas transgênicas em ramos juvenis, obtidos a partir da germinação de sementes in vitro (Peña et al., 1995a). Esta técnica pode ser indicada para o maracujazeiro.

Dentre 111 explantes que apresentaram brotos em meio seletivo, 27

plantas inteiras (Figura 19C) foram regeneradas em meio seletivo com canamicina $(50 \mathrm{mg} / \mathrm{L})$, dentre elas 7 foram submetidas à analise molecular (PCR), e 5 identificadas como transgênicas (Tabela 8).

Foram testados 2 pares de "primers" para amplificação do gene atacina $A$, amplificando os fragmentos esperados de 350 pb e 500 pb (Figura 19D-E). Na primeira tentativa, as duas outras plantas foram descartadas por não amplificarem as bandas correspondentes, mostrando terem havido escapes 
no meio seletivo $\mathrm{MSB}(\mathrm{A}) \mathrm{K}$. Os fragmentos de $350 \mathrm{pb}$ amplificados dos transformantes primários são correspondentes aos de 500pb ( $\mathrm{TO}_{1}$ a $\left.\mathrm{TO}_{5}\right)$, e por sua vez são equivalentes ao controle positivo (plasmídeo pFFatacina). O DNA genômico proveniente da planta não transformada não apresentou amplificação (Figura 19 D-E).

A incorporação do gene uidA não foi avaliada por reação de $\mathrm{PCR}$. Duas plantas regeneradas mostraram em suas folhas expressão de GUS, sendo que em uma delas a coloração azul foi inteiramente tomada na superfície foliar (dados não apresentados).

Se considerarmos a eficiência de co-transformação pelas seleção em meio com antibiótico e pela amplificação do gene atacina $A$, a eficiência de cointegração dos 2 plasmídeos foi de 100\%. Esses dados estão de acordo com a literatura, que mostra ser relativamente alta a freqüência de co-integração de genes não ligados. Em calos embriogênicos de arroz, Breitler et al. (2002) obtiveram $100 \%$ de integração de 2 genes marcadores não ligados (yfp e $h p h$ ) e Chen et al. (1998b) utilizaram 14 genes independentes que foram cobombardeados em tecidos embriogênicos de arroz. Setenta e cinco porcento dos regenerantes obtidos tinham de 2 a 8 genes co-integrados e 17,6\%, 9 a 13 genes.

Apesar dos problemas relacionados à regeneração com a utilização de canamicina (50 mg/L), a seleção dos brotos se deu eficientemente com apenas 2 escapes em 7 plantas analisadas. Por outro lado, Silva (1998) observou incremento de brotos em meio de cultura nessa mesma concentração de canamicina em maracujá amarelo, sendo necessários $100 \mathrm{mg} / \mathrm{L}$ para a seleção. A autora obteve 8 plantas transgênicas, caracterizadas positivamente por PCR para o gene introduzido (nptIl). A hibridização de DNA dessas plantas com a seqüência do gene reduziu o número para 6 , resultando uma freqüência de transformação de $2 \%$, do total de 300 explantes co-cultivados com a Agrobacterium tumefaciens. 

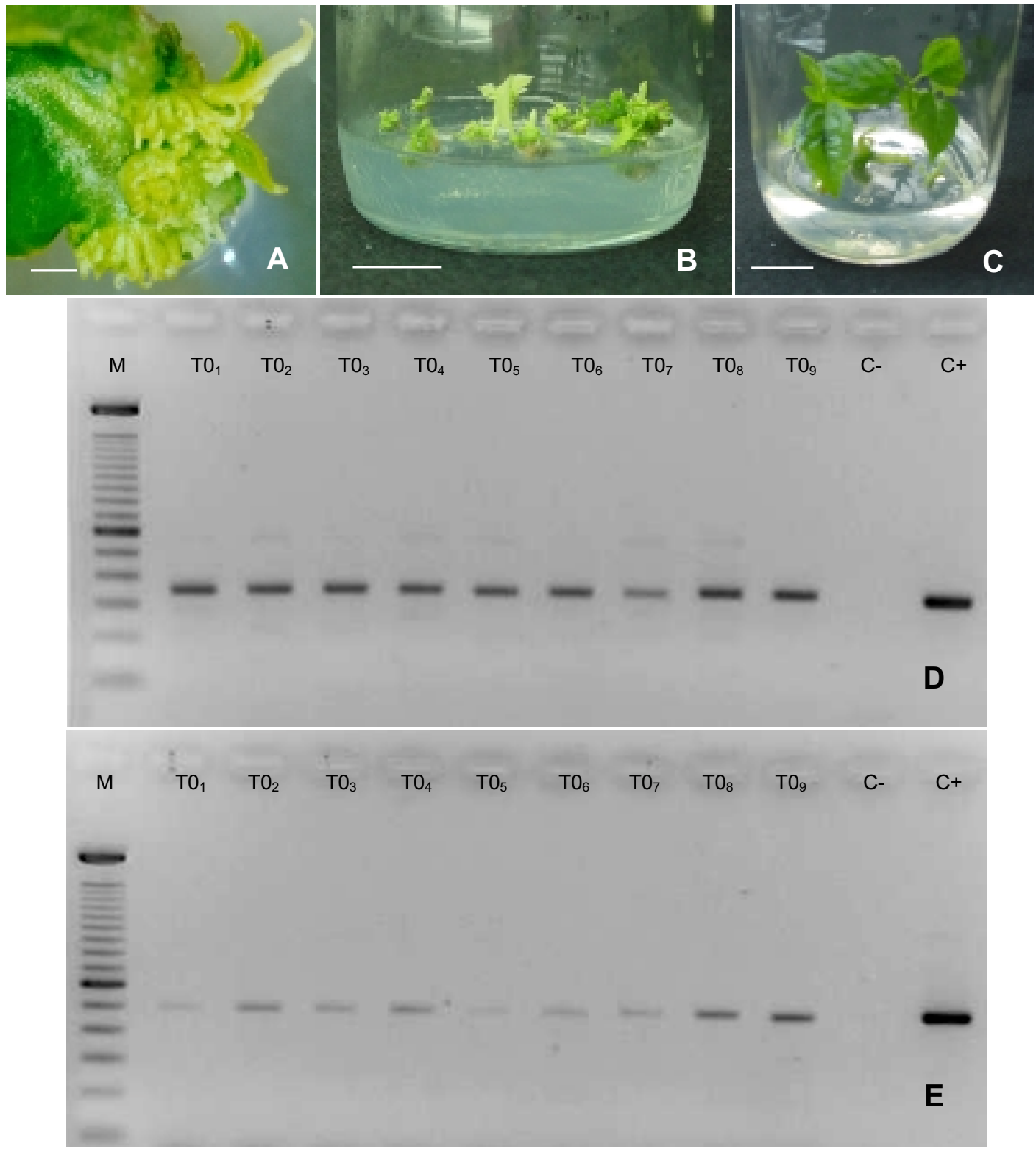

Figura 19 - Seleção e regeneração de plantas de $P$. edulis Sims f. flavicarpa Deg. em meio $\mathrm{MSB}(\mathrm{A}) \mathrm{K}(\mathrm{A}-\mathrm{C})$, e análise por $\mathrm{PCR}$ das plantas transgênicas para o gene atacina $A$ de Trichoplusia ni (D-E). *

* Co-bombardeamento com os plasmídeos pFFatacina/pBI426 ( $\left.\mathrm{TO}_{1}-\mathrm{TO}_{5}\right)$. Bombardeamento com pCatacina $1300\left(\mathrm{TO}_{6}-\mathrm{TO}_{9}\right)$. Planta não transformada (C-: controle negativo) e pFFatacina ( $\mathrm{C}+$ : controle positivo). $\mathrm{M}$ : marcador Ladder $100 \mathrm{pb}$. D- amplificação de fragmentos de 350 pb. E- 500 pb com "primers" específicos para o gene atacina $A$. Barras $=870 \mu \mathrm{m}(A)$ e $2 \mathrm{~cm}(B$ e $C)$. 
Apesar da análise de PCR não comprovar a real integração do gene atacina $A$, os dados aqui apresentados são bons indicativos da sua presença nas plantas analisadas. Também, mostram a eficiência da canamicina como agente seletivo, com apenas 2 escapes em 7 plantas analisadas.

Tabela 8. Resumo dos resultados de co-transformação com os vetores pBI426/pFFatacina e análise molecular de plantas transgênicas por PCR.

\begin{tabular}{|c|c|c|c|c|}
\hline $\begin{array}{c}\text { Tipo de } \\
\text { explante }^{a}\end{array}$ & $\begin{array}{l}\text { Número de } \\
\text { explantes }\end{array}$ & $\begin{array}{c}\text { Seleção em } \\
M S B(A) K^{b}(\%)\end{array}$ & $\begin{array}{c}\text { Plantas } \\
\text { regeneradas (\%) }\end{array}$ & $\begin{array}{c}\text { Análise por PCR } \\
(\%)\end{array}$ \\
\hline \multicolumn{5}{|c|}{ CO-BOMBARDEADOS } \\
\hline Disco foliar & 666 & $111(16,67)$ & $27(4,05)^{c}$ & $5(0,75)$ \\
\hline Calo & 705 & $25(3,55)$ & $2(0,28)^{d}$ & \\
\hline \multicolumn{5}{|l|}{ CONTROLES } \\
\hline Disco foliar & 30 & - & $24(80,0)$ & - \\
\hline Calo & 50 & - & $10(20,0)$ & - \\
\hline
\end{tabular}

a Discos foliares de 3 e calos de 6 dias.

${ }^{\mathrm{b}}$ Meio MS suplementado com $0,5 \mathrm{mg} / \mathrm{L}$ de BA, $5 \%$ de água de coco, $50 \mathrm{mg} / \mathrm{L}$ de canamicina e solidificado com $0,6 \%$ de agar.

c. Dentre as 27 plantas, somente 7 foram submetidas à análise de PCR.

d.Não submetidas à análise molecular.

\subsubsection{Bombardeamento utilizando um único plasmídeo}

Discos foliares e calos de segmentos entrenodais foram bombardeados com o plasmídeo pCatacina 1300. Esse vetor possui o cassete de expressão do gene atacina A (35SP-atacinaA-35ST) ligado ao gene hpt que confere resistência ao antibiótico higromicina.

A Tabela 9 resume os resultados obtidos nesse experimento. A frequência de transformação estável utilizando 1 só vetor foi maior $(1,03 \%)$ em 
comparação ao sistema com 2 vetores que foi de 0,75\% (Tabela 8). Foram bombardeados 390 discos foliares, dos quais 78 sobreviveram à seleção com higromicina e 20 plantas foram regeneradas. Dessas 20, 4 plantas foram analisadas por PCR, as quais mostraram amplificação dos fragmentos esperados, designados de $\mathrm{TO}_{6}$ a $\mathrm{TO}_{9}$ (Figura 19D e E).

Essa freqüência de transformação pode ser explicada quer devido ao melhor ajuste na condição de cultura, quer devido à higromicina como agente seletivo, ou a ambos. A higromicina foi o antibiótico que reduziu a resposta organogênica no teste de agente seletivo (item 4.3). Apesar de $5 \mathrm{mg} / \mathrm{L}$ de higromicina terem permitido o aparecimento de brotos no teste de seleção inicial, a utilização de $3 \mathrm{mg} / \mathrm{L}$ foi favorável à seleção. De fato, a seleção em concentrações mais baixas é recomendada inicialmente, para que o estresse sofrido pelo explante no bombardeamento não leve à não detecção de transformantes.

Problemas relacionados à canamicina como agente seletivo em maracujazeiro podem ser evitados com a utilização de higromicina. Os principais problemas citados são: interação do agente solidificante $x$ canamicina na regeneração (Silva, 1998; Reis, 2001), resistência natural dos transformantes ao antibiótico, sendo essa a razão da alta concentração utilizada (50 - $150 \mathrm{mg} / \mathrm{L})$, escapes freqüentes pelo fato da resistência ser devida à enzima que detoxifica o antibiótico do meio, causando a "proteção cruzada" das células próximas aos tecidos não transformados.

Em mandioca, a freqüência de transformação foi de 0,6 e 1,2\% para os genótipos, MCol22 e TMS60444, respectivamente (Zhang et al., 2000), semelhante ao observado no presente estudo que mostra a eficiência de seleção pela higromicina. 
Tabela 9. Resumo dos resultados de transformação com o vetor pCatacina 1300 e análise molecular de plantas transgênicas por PCR.

\begin{tabular}{ccccc}
\hline $\begin{array}{c}\text { Tipo de } \\
\text { explante }\end{array}$ & $\begin{array}{c}\text { Número de } \\
\text { explantes }\end{array}$ & $\begin{array}{c}\text { Seleção em } \\
\text { MSB(A) } H^{\mathrm{b}}(\%)\end{array}$ & $\begin{array}{c}\text { Plantas } \\
\text { regeneradas }(\%)\end{array}$ & $\begin{array}{c}\text { Análise por PCR } \\
(\%)\end{array}$ \\
\hline $\begin{array}{c}\text { BOMBARDEADOS } \\
\text { Disco foliar } \\
\text { Calo }\end{array}$ & 390 & $78(20,0)$ & $20(5,13)^{\mathrm{c}}$ & $4(1,03)$ \\
CONTROLES & 140 & $12(8,57)$ & & \\
$\begin{array}{c}\text { Disco foliar } \\
\text { Calo }\end{array}$ & 30 & - & $24(80,0)$ & - \\
\hline
\end{tabular}

a Discos foliares de 3 e calos de 6 dias.

${ }^{b}$ Meio MS suplementado com $0,5 \mathrm{mg} / \mathrm{L}$ de $\mathrm{BA}, 5 \%$ de água de coco, $3 \mathrm{mg} / \mathrm{L}$ de higromicina e solidificado com $0,6 \%$ de agar.

c.Dentre as 20 plantas, somente 4 foram submetidas à análise de PCR.

\subsubsection{Síntese dos experimentos de transformação e perspectivas futuras}

Plantas transgênicas de maracujazeiro amarelo carregando o gene atacina $A$, o qual codifica uma proteína bactericida, foram efetivamente caracterizadas por PCR. A análise dos dois sistemas de bombardeamento está apresentada na Tabela 10.

Uma freqüência estável de transformação de 0,85\% foi obtida, e há possibilidade dessa porcentagem aumentar. Uma população de 36 plantas encontra-se em fase de enraizamento. São transgênicos putativos (22 de cotransformação, sendo que 2 deles são provenientes de calo, e 14 transformados com pCatacina 1300).

Para gerar uma planta resistente ou tolerante à Xanthomonas campestris pv. passiflorae, que é o objetivo final do projeto, estudos moleculares subsequentes (Southern blot, Northern e Western blot), assim como ensaios biológicos são necessários a fim de verificar a integração, expressão e atividade, e a ação da proteína. 
Tabela 10. Resumo geral de transformação por biobalística com o gene atacina A (pFFatacina e pCatacina 1300).

\begin{tabular}{ccccc}
\hline $\begin{array}{c}\text { Tipo de } \\
\text { explante }\end{array}$ & $\begin{array}{c}\text { Número de } \\
\text { explantes }\end{array}$ & $\begin{array}{c}\text { Seleção em } \\
\mathrm{MSB}(\mathrm{A}) \mathrm{K} / \mathrm{H}^{\mathrm{b}}(\%)\end{array}$ & $\begin{array}{c}\text { Plantas } \\
\text { regeneradas }(\%)\end{array}$ & $\begin{array}{c}\text { Análise por PCR } \\
(\%)\end{array}$ \\
\hline $\begin{array}{c}\text { Disco foliar } \\
\text { Calo }\end{array}$ & 1056 & $189(17,90)$ & $47(4,45)^{\mathrm{c}}$ & $9(0,85)$ \\
\hline
\end{tabular}

a Discos foliares de 3 e calos de 6 dias.

${ }^{\mathrm{b}}$ Meio MS suplementado com $0,5 \mathrm{mg} / \mathrm{L}$ de $\mathrm{BA}, 5 \%$ de água de coco, $50 \mathrm{mg} / \mathrm{L}$ de canamicina ou $3 \mathrm{mg} / \mathrm{L}$ de higromicina e solidificado com $0,6 \%$ de agar.

c. 36 transgênicos putativos.

Em comparação com as plantas que têm o sistema de transformação por biobalística bem estabelecido usando calos embriogênicos, a freqüência de transformantes resgatados no presente estudo foi baixa (0,85\%). Em milho, as freqüências de transformação por biobalística são de $45 \%$ quando a manose foi utilizada como agente seletivo (Wright et al., 2001) e 15\% utilizando-se o herbicida Basta (Wright et al., 2001). Em trigo, a frequência média utilizando herbicida ou manose foi de $12 \%$ (Wright et al., 2001). No entanto, a média mais freqüentemente encontrada não excede 1\% (Barro et al., 1998; Witrzens et al., 1998; Bliffeld et al., 1999).

Para aumentar a freqüência de transformação do maracujazeiro, um maior número de explantes deve ser bombardeado, da ordem de 5.000. Como as chances de recuperação de plantas transgênicas é baixa, a população de explantes deve ser representativa. Também, como a elongação dos brotos se deu de forma lenta, espera-se encontrar um maior número de transgênicos na medida que um maior número de brotos seja avaliado por PCR.

Outros parâmetros podem ser avaliados como, por exemplo, tratamentos osmóticos (plasmólise) durante o pré e pós-bombardeamento. $\mathrm{O}$ emprego de substâncias como manitol e sorbitol aumentam a osmolaridade do meio de bombardeamento podendo aumentar a eficiência de transformação. A presença de osmóticos faz com que as células sofram uma redução em sua pressão de turgor e, conseqüentemente, facilite a penetração da partícula e 
evite que as células estourem ou extravasem seu conteúdo citoplasmático (Nandadeva et al., 1999). Esse tratamento aumentou a freqüência de transformação por biobalísta em milho, trigo (Wright et al., 2001) e mandioca (Zhang et al., 2000).

Este é o primeiro trabalho de transformação genética por biobalística em maracujazeiro no qual um gene de interesse (atacina $A$ ) que codifica uma proteína bactericida foi introduzido. Produziu 9 plantas transgênicas que podem ser usadas como doadoras de pólen para disseminar o transgene para genótipos elites.

\subsubsection{Maracujá transgênico: riscos e recomendações}

A utilização de maracujazeiro transgênico, particularmente no Brasil, deve ser bem controlada por duas razões: (i) é uma planta alógama e (ii) o Brasil é o centro de diversidade genética, com cerca de 150 espécies de Passiflora distribuídas nas regiões Central e Norte do Brasil, considerado o principal centro de distribuição geográfica.

O escape dos transgenes via pólen é um risco, principalmente nas culturas em que a taxa de fluxo gênico é alta dentro da espécie cultivada e/ou entre esta e as formas silvestres do gênero. Apesar da incompatibilidade sexual entre as espécies de maracujazeiro, há compatibilidade bastante acentuada entre as formas amarela e a roxa, sendo ambas cultivadas.

Diante disso, a transformação do genoma de cloroplasto, o qual tem herança materna para a grande maioria das espécies vegetais, pode ser uma boa alternativa. A transformação de plastídeos com os genes de resistência a herbicida e a inseto são atualmente realizados com sucesso (Daniell, 1999) e estudos vêm sendo realizados para outros patógenos (bactérias e fungos) (DeGray et al., 2001).

Outra preocupação diz respeito à: (i) transferência horizontal dos genes de resistência a antibióticos para microrganismos associados à planta 
(Kidwell, 1993; Schlüter et al., 1995); (ii) dos genes de resistência a herbicida para plantas invasoras (Rogers \& Parkes, 1995), e (iii) do aumento na pressão de seleção para resistência (Schulz et al., 1990). Isto favorece o emprego de sistemas que permitam a retirada desses genes após a seleção (como o sistema Cre/lox, co-bombardeamento), ou a substituição desses agentes por outros (manose/xilose), ou o emprego da regeneração na ausência de agente seletivo.

Apesar dos trabalhos de transformação com proteínas bactericidas não mencionarem o seu efeito na flora exofítica ou endofítica, são também necessários estudos neste sentido. 


\section{CONCLUSÕES}

Os estudos realizados neste trabalho permitiram que se chegasse às seguintes conclusões:

1) Ocorre resposta morfogênica direta e indireta de $P$. edulis Sims f. flavicarpa Deg., população Sul Brasil, em meio $\mathrm{MSB}(\mathrm{A})$ : sais e vitaminas $\mathrm{MS}, 0,5 \mathrm{mg} / \mathrm{L}$ de $B A, 5 \%$ de água de coco e solidificado com agar $(0,6 \%)$.

2) A via de organogênse direta ocorre a partir de discos foliares enquanto a indireta, a partir de segmentos entrenodais e/ou hipocotiledonares (2 $\mathrm{mm}$ ). Cerca de 50 brotos e 300 estruturas semelhantes a gemas são obtidas de discos e segmentos entrenodais e/ou hipocotiledonares, respectivamente. A regeneração é bastante reduzida na fase de elongação, principalmente pela via indireta.

3) A higromicina é eficiente como agente seletivo, inibindo a organogênese em $60 \%$ dos explantes a $5 \mathrm{mg} / \mathrm{L}$. Canamicina a $50 \mathrm{mg} / \mathrm{L}$ e geneticina a $15-20$ $\mathrm{mg} / \mathrm{L}$ de geneticina são suficientes na seleção inicial.

4) Plantas transgênicas contendo o gene exógeno atacina $A$, usando cobombardeamento (pB|426/pFFatacina) e seleção a $50 \mathrm{mg} / \mathrm{L}$ de canamicina, são obtidas a uma freqüência estável de transformação de 0,75\%. Quando um um único vetor (pCatacina 1300) é utilizado por seleção com $3 \mathrm{mg} / \mathrm{L}$ de higromicina, obtém-se freqüência de 1,03\%. 
ANEXOS 


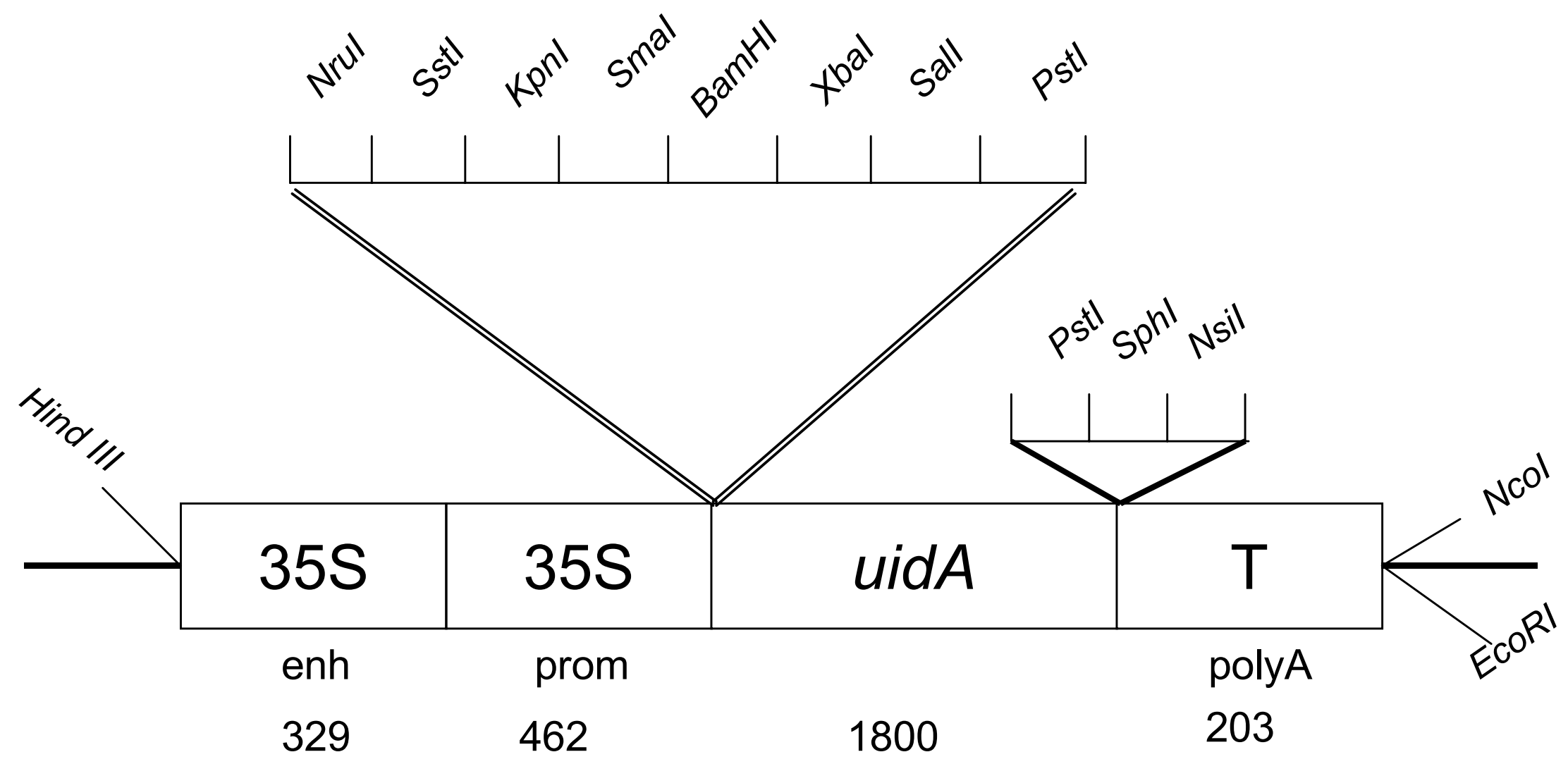

Anexo A - Vetor pFF19G (6,0 kb). O comprimento do cassete de expressão é representado em pb. 


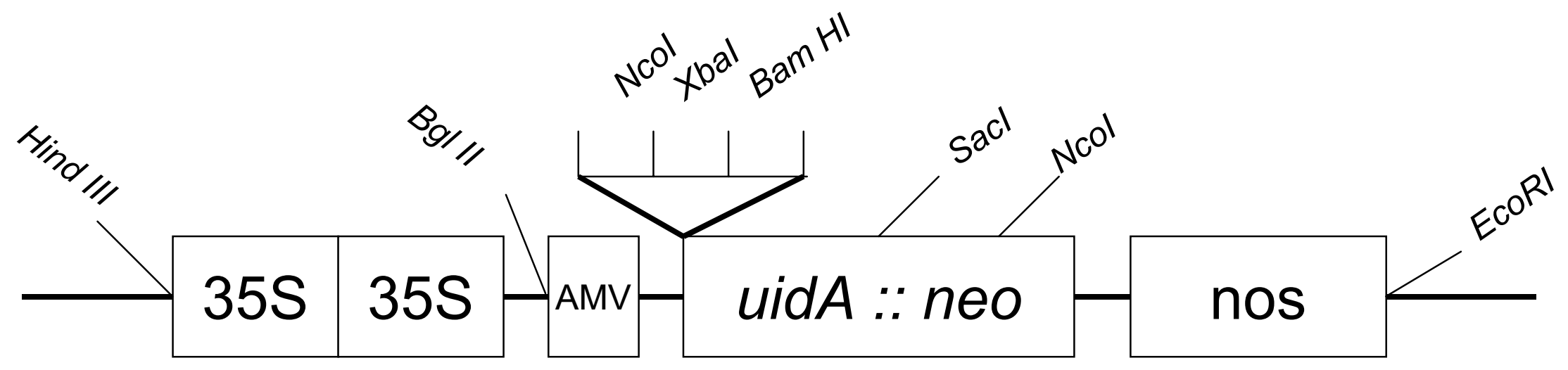

Anexo B - Vetor pBI426 (8,7 kb). 


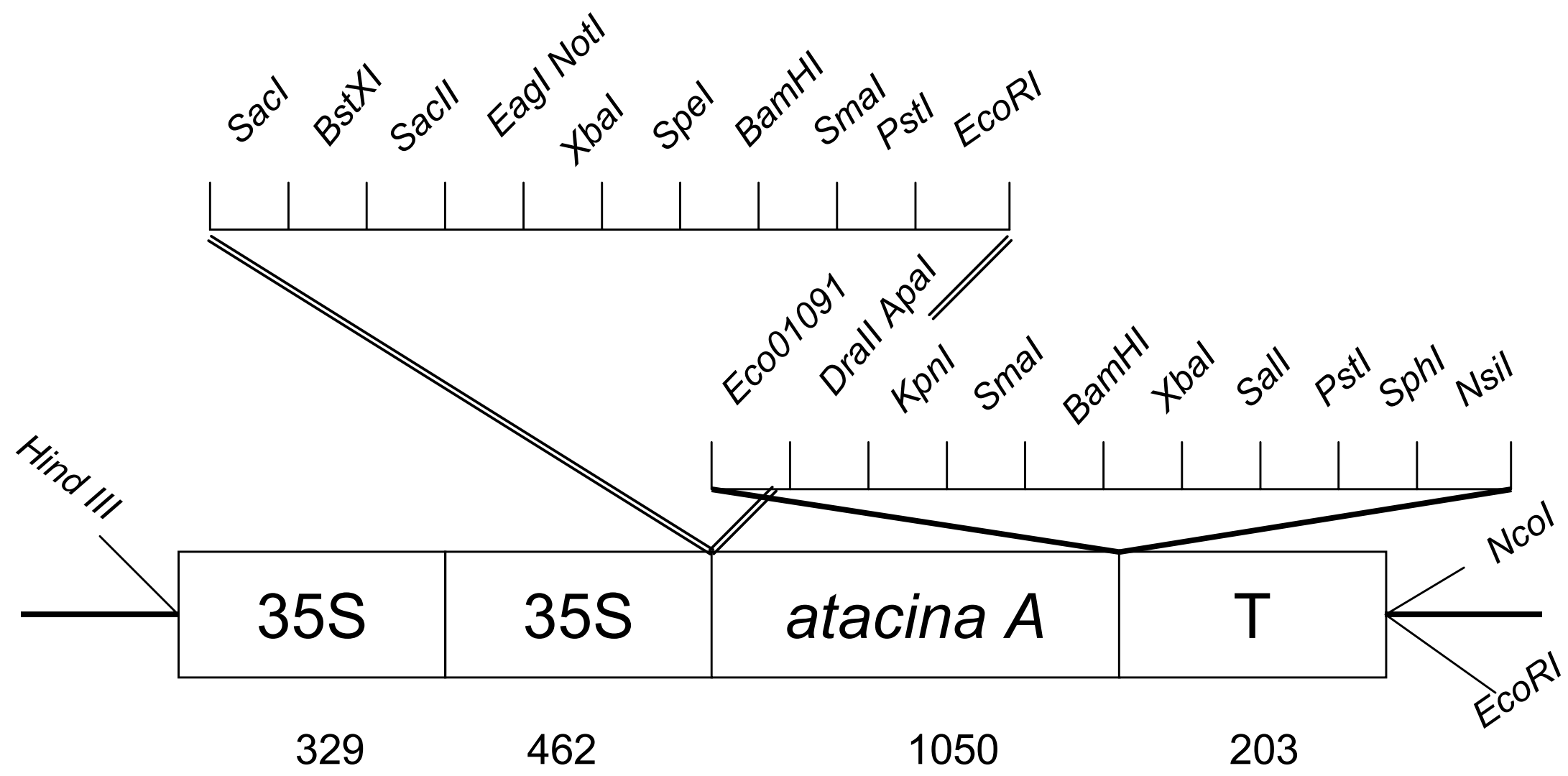

Anexo C - Vetor pFFatacina (5,25 kb). O comprimento do cassete de expressão é representado em pb. 


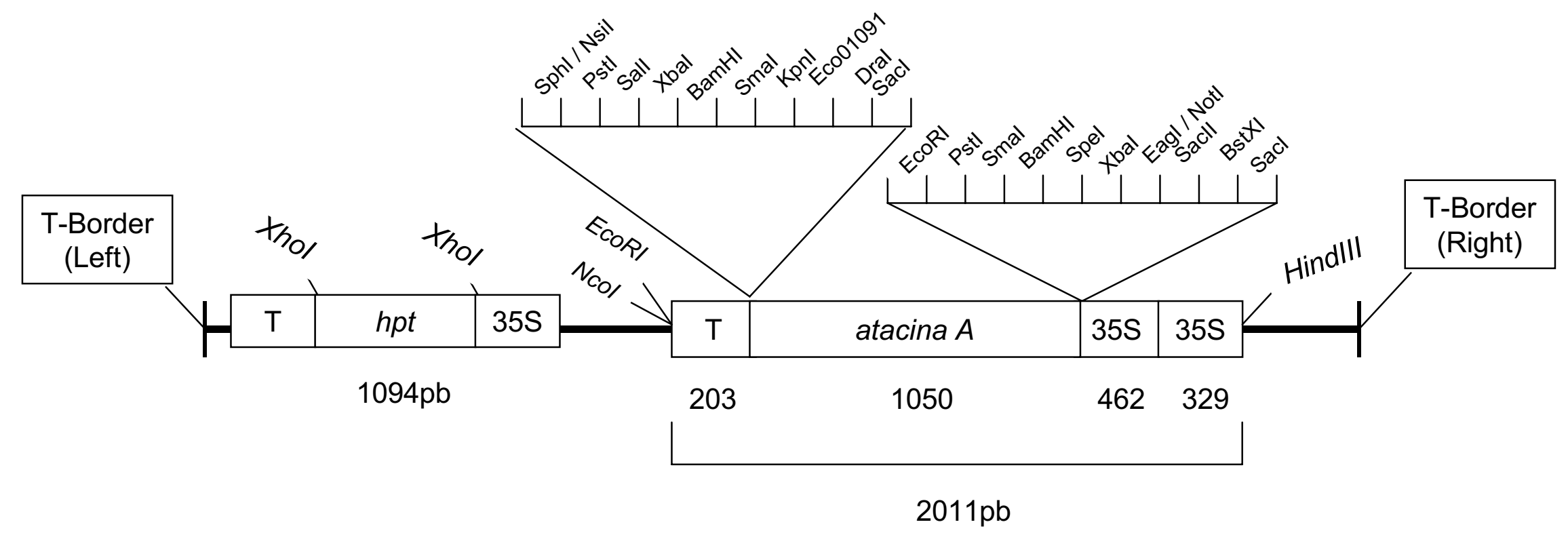

Anexo D - Vetor pCatacina 1300 (10,965 kb). 


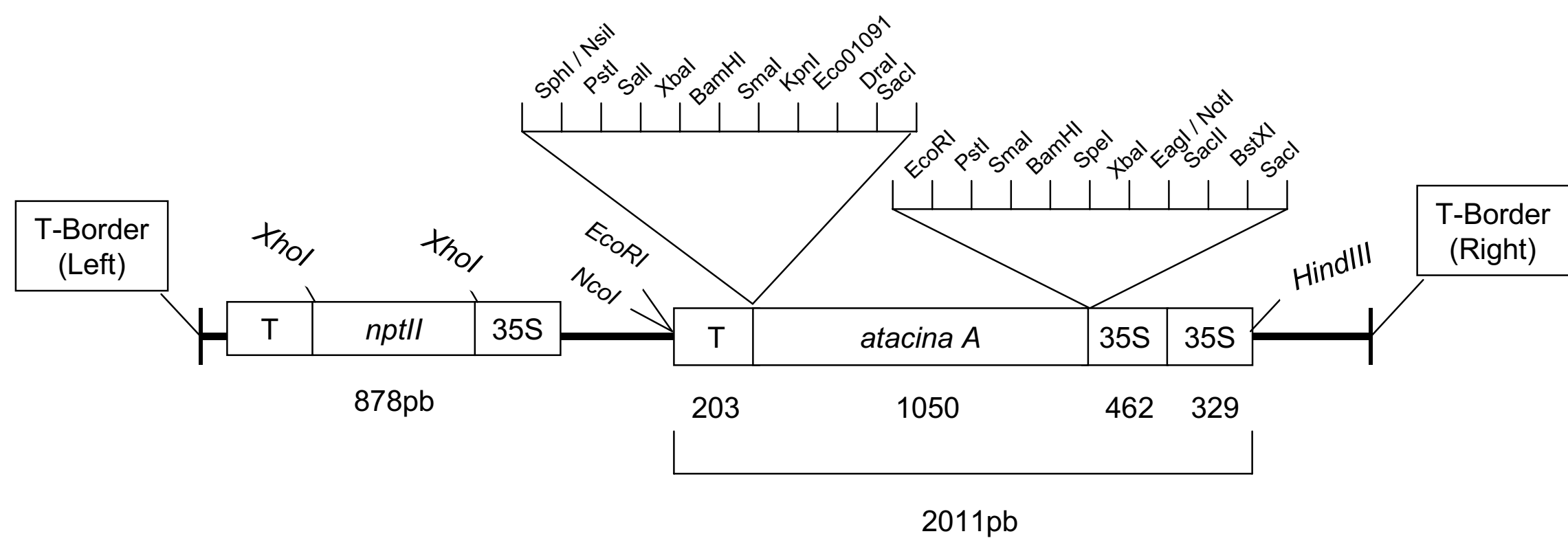

Anexo E - Vetor pCatacina $2300(10,753 \mathrm{~kb})$. 


\section{REFERÊNCIAS BIBLIOGRÁFICAS}

ADANG, M.J.; BRODY, M.S.; CARDINEAU, G. The reconstruction and expression of a Bacillus thuringiensis cryIIIA gene in protoplasts and potato plants. Plant Molecular Biology, v.21, p.1131-1145, 1993.

AHMAD, A.; MAQBOOL, S.B.; RIAZUDDIN, S.; STICKLEN, M.B. Expression of synthetic cry $1 A b$ and cry $1 A c$ gens in Basmati rice (Oryza sativa L.) variety 370 via Agrobacterium-mediated transformation for the control of the European corn borer (Ostrinia nubilalis). In Vitro Cellular \& Developmental Biology-Plant, v.38, p.213-220, 2002.

AKAMA, H.; SHIRAISHI, H.; OHTA, S.; NAKAMURA, K.; OKADA, K.; SHIMURA, Y. Efficient transformation of Arabidopsis thaliana: Comparison of the efficiencies with various organs, plant ecotypes and Agrobacterium strains. Plant Cell Reports, v.1, p.7-11, 1992.

ALFANO, J.R.; COLLMER, A. Bacterial pathogens in plants: life up against the wall. The Plant Cell, v.8, p.1683-1698, 1996.

ALLEFS, S.J.H.M.; FLORACK, D.E.A.; HOOGENDOORN, C.; STIEKEMA, W.J. Erwinia soft rot resistance of potato cultivars transformed with a gene construct coding for antimicrobial peptide cecropin B is not altered. American Potato Journal, v.72, p.437-445, 1995.

APPEZZATO-DA-GLORIA, B. Aspectos histológicos e ultra-estruturais da organogênese somática in vitro de três espécies de leguminosas. Piracicaba, 1998. 74p. Tese (Livre-Docência) - Escola Superior de Agricultura "Luiz de Queiroz", Universidade de São Paulo. 
APPEZZATO-DA-GLORIA, B.; VIEIRA, M.L.C.; DORNELAS, M.C. Anatomical studies of in vitro organogenesis induced in leaf-derived explantes of passionfruit. Pesquisa Agropecuária Brasileira, v.34, p.2007-2013, 1999. ARAGÃO, F.J.L.; BARROS, L.M.G.; BRASILEIRO, A.C.M.; RIBEIRO, S.G.; SMITH, F.D.; SANFORD, J.C.; FARIA, J.C.; RECH, E.L. Inheritance of foreign genes in transgenic bean (Phaseolus vulgaris L.) co-transformed via particle bombardment. Theoretical and Applied Genetics, v.152, p.120134, 1996.

ARMSTRONG, C. The first decade of maize transformation: a review and future perspective. Maydica, v.44, p.101-109, 1999.

ASLING, B.; DUSHAY, M.S.; HULTIMARK, D. Identification of early genes in the Drosophila immune response by PCR-based differential display: the attacinlike proteins. Insect Biochemistry and Molecular Biology, v.25, p.511518, 1995.

BANNO, H.; IKEDA, Y. NIU, Q-W.; CHUA, N-H. Overexpression of Arabidopsis ESR1 induces initiation of shoot regeneration. The Plant Cell, v.13, p.26092618, 2001.

BARBOSA, L.V.; VIEIRA, M.L.C. Meiotic behavior of passion fruit somatic hybrids, Passiflora edulis f. flavicarpa Degener $+P$. amethystina Mikan. Euphytica, v.98, p.121-127, 1997.

BARBOSA, W.M.; OTONI, W.C.; CARNELOSSI, M.; SILVA, E.; AZEVEDO, A.A.; VIEIRA, G. Rhizogenesis in in vitro shoot cultures of passion fruit (Passiflora edulis f. flavicarpa Deg.) is affected by ethylene precursor and by inhibitors. International Journal of Horticultural Science, v.7, p.47-51, 2001.

BARRO, F.; CANNELL, M.E.; LAZZERI, P.A.; BARCELO, P. The influence of auxins on transformation of wheat and tritordeum and analysis of transgene integration patterns in transformants. Theoretical and Applied Genetics, v.97, p.684-695, 1998. 
BECKER, D.K.; DUGDALE, B.; SMITH, M.K.; HARDING, R.M.; DALE, J.L. Genetic transformation of Cavedish banana (Musa spp. AAA group) cv "Grand Nain" via microprojectile bombardment. Plant Cell Reports, v.19, p.229-234, 2000.

BEVAN, M. Binary Agrobacterium vectors for plant transformation. Nucleic Acid Research, v.12, p.8711-8721, 1984.

BEVAN, M.W.; FLAVEL, R.B.; CHILTON, M.D.A chimaeric antibiotic resistance marker gene as a selectable marker for plant cell transformation. Nature, v.304, p.184-487, 1983.

BIASI, L.A.; FALCO, M.C.; RODRIGUEZ, A.P.M.; MENDES, B.M.J. Organogenesis from internodal segments of yellow passion fruit. Scientia Agricola, v.57, p.661-665, 2000.

BLAIR-KERTH, L.K.; DOTRAY, P.A.; KEELING, J.W.; GANNAWAY, J.R.; OLIVER, M.J.; QUISENBERRY, J.E. Tolerance of transformed cotton to glufosinate. Weed Science, v.49, p.375-380, 2001.

BLIFFELD, M.; MUNDY, J.; POTRYKUS, I.; FÜTTERER, J. Genetic engineering of wheat for increased resistance to powdery mildew disease. Theoretical and Applied Genetics, v.98, p.1079-1086, 1999.

BLISKA, F.M.M.; LEITE, R.S.S.; GARCIA, A.E.B. Produção de maracujá no Brasil e sua comercialização nas principais centrais de abastecimento. In: JOSÉ, A.R.S. (Ed.). Maracujá, produção e mercado. Vitória da Conquista: DFZ/UESB, 1994. p.206-222.

BOGORAD, L. Engineering chloroplasts: an alternative site for foreign genes, proteins, reactions and products. Trends in Biotechnology, v.18, p.257263, 2000.

BOGS, J.; BRUCHMüLLER, I.; ERBAR, C.; GEIDER, K. Colonization of host plants by the fire blight pathogen Erwinia amylovora marked with genes for bioluminescence and fluorescence. Phytopathogy, v.88, p.416-421, 1998. 
BOMAN, H.G.; FAYE, I.; GUDMUNDSSON, G.H.; LEE, J-Y.; LIDHOLM, D-A. Cell-free immunity in Cecropia. European Journal of Biochemistry, v.201, p.23-31, 1991.

BOMAN, H.G.; HULTMARK, D. Cell-free immunity in insects. Annual Review Microbiology, v.41, p.103-126, 1987.

BOND, J.E.; ROOSE, M.L. Agrobacterium-mediated transformation of the commercially important citrus cultivar Washington navel orange. Plant Cell Reports, v.18, p.229-234, 1998.

BRASILEIRO, A.C.M.; CARNEIRO, V.T. de C. Manual de transformação genética de plantas. Brasília: Embrapa-SPI/Embrapa-Cenargen, 1998. 309p.

BRAZ, A.S.K. Clonagem e seqüenciamento dos genes da proteína capsidial e da replicase de um Potyvirus causador de endurecimento dos frutos do maracujazeiro, e transformação de maracujá-amarelo com construção derivada desses genes. Viçosa, 1999. 106p. Dissertação (M.S.) Universidade Federal de Viçosa.

BREITLER, J.C.; LABEYRIE, A.; MEYNARD, D.; LEGAVRE, T.; GUIDERDONI, E. Efficient microprojectile bombardment-mediated transformation of rice using gene cassettes. Theoretical and Applied Genetics, v.104, p.709719, 2002.

BRUCKNER, C.H. Perspectivas do melhoramento genético do maracujazeiro. In: SÃO JOSÉ, A.R.; BRUCKNER, C.H.; MANICA, I.; HOFFMANN, M. (Ed.). Maracujá: temas selecionados (1): melhoramento, morte prematura, polinização, taxonomia. Porto Alegre: Cinco Continentes, 1997. p.7-24.

BUDDENDORF-JOOSTEN, J.M.C.; WOLTERING, E.J. Components of the gaseous environment and their effects on plant growth and development in vitro. Plant Growth Regulator, v.15, p.1-6, 1994.

BUTTERFIELD, M.K.; IRVINE, J.E.; GARZA, M.V.; MIRKOV, T.E. Inheritance and segregation of virus and herbicide resistance transgenes in sugarcane. Theoretical and Applied Genetics, v.104, p.797-803, 2002. 
CARLSSON, A.; ENGSTRÖM, P.; PALVA, E.T.; BENNICH, H. Attacin, an antibacterial protein from Hyalophora cecropia, inhibits synthesis of outer membrane proteins in Escherichia coli by interfering with omp gene transcription. Infection and Immunity, v.59, p.3040-3045, 1991.

CARLSSON, A.; NYSTRÖM, T.; COCK, H. de; BENNICH, H. Attacin: an insect immune protein: binds LPS and triggers the specific inhibition of bacterial outer-membrane protein synthesis. Microbiology, v.144, p.2179-2188, 1998.

CARNEIRO, M.S. Mapas de ligação de maracujá amarelo (Passiflora edulis Sims f. flavicarpa Deg.) baseados em marcadores RAPD. Piracicaba, 2001. 92p. Tese (Doutorado) - Escola Superior de Agricultura "Luiz de Queiroz", Universidade de São Paulo.

CARRER, H.; STAUB, J.M.; MALIGA, P. Gentamycin resistance in Nicotiana conferred by $\mathrm{AAC}(3)-\mathrm{I}$, a narrow substrate specificity acetyltransferase. Plant Molecular Biology, v.17, p.301-303, 1991.

CARY, A.; UTTAMCHANDANI, S.J.; SMETS, R.; VAN ONCKELEN, H.A.; HOWELL, S.H.H. Arabidopsis mutants with increased organ regeneration in tissue culture are more competent to respond to hormonal signals. Planta, v.213, p.700-707, 2001.

CATLIN, D.W. The effect of antibiotics on the inhibition of callus induction and plant regeneration from cotyledons of sugarbeet (Beta vulgaris L.). Plant Cell Reports, v.9, p.285-288, 1990.

CHAREST, P.J.; CALÉRO, N.; LACHANCE, D.; DATLA, R.S.S.; DUCHESNE, L.C.; TSANG, E.W.T. Microprojectile-DNA delivery in conifer species: factors affecting assessment of transient gene expression using the $\beta$ glucuronidase reporter gene. Plant Cell Reports, v.12, p.189-193, 1993.

CHAUVIN, J-E; MARHADOUR, S.; COHAT, J.; NARD, M.L. Effects of gelling agents on in vitro regeneration and kanamycin efficiency as a selective agent in plant transformation procedures. Plant Cell, Tissue and Organ Culture, v.58, p.213-217, 1999. 
CHEN, F-C.; KUEHNLE, A.R. Obtaining transgenic Anthurium through Agrobacterium mediated transformation of etiolated internodes. Journal of de American Society for Horticultural Science, v.121, p.47-51, 1996.

CHEN, L.; MARMEY, P.; TAYLOR, N.J.; BRIZARD, J-P.; ESPINOZA, C.; D'CRUZ, P.; HUET, H.; ZHANG, S.; KOCHKO, A. de; BEACHY, R.N.; FAUQUET, C.M. Expression and inheritance of multiple transgenes in rice plants. Nature Biotechnology, v.16, p.1060-1064, 1998b.

CHEN, W.P.; CHEN, P.D.; LIU, D.J.; KYNAST, R.; FRIEBE, B.; VELAZHAHAN, R.; MUTHUKRISHNAN, S.; GILL, B.S. Development of wheat scab symptoms is delayed in transgenic wheat plants that constitutively express a rice thaumatin-like protein gene. Theoretical and Applied Genetics, v.99, p.755-760, 1999.

CHEN, W.P.; GU, X.; LIANG, G.H.; MUTHUKRISHNAN, S.; CHEN, P.D.; LIU, D.J. Introduction and constitutive expression of a rice chitinase gene in bread wheat using biolistic bombardment and the bar gene as a selectable marker. Theoretical and Applied Genetics, v.97, p.1296-1306, 1998a.

CHRISTIANSON, M.L.; WARNICK, D.A. Competence and determination in the process of in vitro shoot organogenesis. Developmental Biology, v.95, p.288-293, 1983.

CHRISTIANSON, M.L.; WARNICK, D.A. Phenocritical times in the process of in vitro shoot organogenesis. Developmental Biology, v.101, p.382-390, 1984.

CHRISTIANSON, M.L.; WARNICK, D.A. Temporal requirement for phytohormone balance in the control of organogenesis in vitro. Developmental Biology, v.112, p.494-497, 1985.

CHRISTOU, P. Soybean transformation by electric discharge particle acceleration. Physiologia Plantarum, v.79, p.163-167, 1990.

CHRISTOU, P. Strategies for variety-independent genetic transformation of important cereals, legumes and woody species utilizing particle bombatdment. Euphytica, v.85, p.13-27, 1995. 
CHRISTOU, P.; FORD, T.L.; KOFRON, M. Production of transgenic rice (Oryza sativa L.) plant from agronomically important indica, and japonica varieties via electric discharge particle acceleration of exogenous DNA into immature zygotic embryos. Bio/Technology, v.9, p.957-962, 1991.

CHRISTOU, P.; McCABE, D.E.; SWAIN, F. Stable transformation of soybean callus by DNA-coated gold particles. Plant Physiology, v.87, p.671-674, 1988.

CLARK, D.G.; GUBRIUM, E.K.; BARRETT, J.E.; NELL, T.A.; KLEE, H. Root formation in ethylene-insensitive plants. Plant Physiology, v.121, p.53-59, 1999.

COLLIN, H.A.; EDWARDS, S. Plant cell culture. Oxford: Bios Scientific Publishers, 1998. 176p.

COMAI, L.; STALKER, D. Mechanism of action of herbicides and their molecular manipulation. Oxford Surveys of Plant Molecular \& Cell Biology, v.3, p.166-195, 1986.

DANIELL, $H$. The next generation of genetically engineered crops for herbicide and insect resistance: containment of gene pollution and resistant insects. AgBiotechNet, v.1, p.1-7, 1999.

DATLA, R.S.; BEKKAOUI, F.; HAMMERLINDL, J.K.; PILATE, G.; DUNSTAN, D.I.; CROSBY, W.L. Improved high-level constitutive foreign gene expression in plants using an AMV RNA4 untranslated leader sequence. Plant Science, v.94, p.139-149, 1993.

DATLA, R.S.; HAMMERLINDL, J.K.; PELCHER, L.E.; CROSBY, W.L.; SELVARAJ, G. A bifunctional fusion between beta-glucuronidase and neomycin phosphotransferase: a broad-spectrum maker enzyme for plants. Gene, v.101, p.239-246, 1991.

DE BLOCK, J.; BOTTERMAN, J.; VANDEWIELE, M.; DOCKX, J.; THOEN, C.; GOSSELE, V.; RAO MOVVA, N.; THOMPSON, C.; VAN MONTAGU, M.; LEEMANS, J. Engineering herbicide resistance in plants by expression of a detoxifying enzyme. EMBO Journal, v.6, p.2513-2518, 1987. 
DEBERGH, P.C.; READ, P.E. Micropropagation. In: DEBERGH, P.C.; ZIMMERMAN.; R.H. (Ed.). Micropropagation: technology and application. Dordrecht: Kluwer, 1991. p.1-13.

DeGRAY, G.; RAJASEKARAN, K.; SMITH, F.; SANFORD, J.; DANIELL, H. Expression of an antimicrobial peptide via the chloroplast genome to control phytopathogenic bacteria and fungi. Plant Physiology, v.127, p.852-862, 2001.

DEKEYSER, R.; CLAES, B.; MARICHAL, M.; VAN MONTAGU, M.; CAPLAN, A. Evaluation of selectable markers for rice transformation. Plant Physiology, v.90, p.217-223, 1989.

DELANNAY, X.; BAUMAN T. T.; BEIGHLEY, D.H.; BUETTNER, M.J., COBLE, H.D.; DEFELICE, M.S.; DERTING, C.W.; DIEDRICK, T.J.; GRIFFIN, J.L.; HAGOOD, E.S.; HANCOCK, F.G.; HART, S.E.; LAVALLEE, B.J.; LOUX, M.M.; LUESCHEN, W.E.; MATSON, K.W.; MOOTS, C.K.; MURDOCK, E.; NICKELL, A.D.; OWEN, M.D.K.; PASCHALL, E.H., PROCHASKA, L.M.; RAYMOND, P.J.; REYNOLDS, D.B.; RHODES, W.K.; ROETH, F.W.; SPRANKLE, P.L.; TAROCHIONE, L.J.; TINIUS, C.N.; WALKER, R.H.; WAX, L.M.; WEIGELT, H.D.; PADGETTE, S.R. Yield evaluation of a glyphosate-tolerant soybean line after treatment with glyphosate. Crop Science, v.35, p.1461-1467, 1995.

DONALDSON, P.A.; ANDERSON, T.; LANE, B.G.; DAVIDSON, A.L.; SIMMONDS, D.H. Soybean plants expressing an active oligomeric oxalate from the wheat $g f-2.8$ (germin) gene are resistant to the oxalate-secreting pathogen Sclerotina sclerotiorum. Physiological and Molecular Plant Pathology, v.59, p.297-307, 2001.

DORNELAS, M.C. Cultura e fusão de protoplastos de Passiflora spp. Piracicaba, 1995. 182p. Dissertação (M.S.) - Escola Superior de Agricultura "Luiz de Queiroz", Universidade de São Paulo. 
DORNELAS, M.C.; TAVARES, F.C.A.; VIEIRA, M.L.C. Plant regeneration from protoplast fusion in Passiflora spp. Plant Cell Reports, v.15, p.106-110, 1995.

DORNELAS, M.C.; VIEIRA, M.L.C. Tissue culture studies on species of Passiflora. Plant Cell, Tissue and Organ Culture, v.36, p.211-217, 1994.

DUGDALE, B.; BECKER, D.K.; BEETHAM, P.R.; HARDING, R.M.; DALE, J.L. Promoters derived from banana bunchy top virus DNA -1 to -5 direct vascular-associated expression in transgenic banana (Musa spp.). Plant Cell Reports, v.19, p.810-814, 2000.

DUNWELL, J.M. Transgenic approaches to crop improvement. Journal of Experimental Botany, v.51, p.487-496, 2000.

DÜRING, K. Genetic engineering for resistance to bacteria in transgenic plants by introduction of foreign genes. Molecular Breeding, v.2, p.297-305, 1996. DUSHAY, M.S.; ROETHELE, J.B.; CHAVERRI, J.M.; DULEK, D.E.; SYED, S.K.; KITAMI, T.; ELDON, E.D. Two attacin antibacterial genes of Drosophila melanogaster. Gene, v.246, p.49-57, 2000.

DYE, D.W.; BRADBURY, J.F.; GOTO, M.; HAYWARD, A.C.; LELLIOT, R.A.; SOHRO, M.N. International standards for naming pathovars of phytopathogenic bacteria and a list of pathovar names and pathotype strains. Review of Plant Pathology, v.59, p.153-168, 1980.

EDWARDS, K.; JOHNSTONE, C.; THOMPSON, C. A simple and rapid method for the preparation of plant genomic DNA for PCR analysis. Nucleic Acid Research, v.19, p.1349, 1991.

ENDO, S.; KASAHARA, T.; SUGITA, K.; MATSUNAGA, E.; EBINUMA, H. The isopentenyl transferase gene is effective as a selectable marker gene for plant transformation in tobacco (Nicotiana tabacum cv. Petite Havana SRI). Plant Cell Reports, v.20, p.60-66, 2001. 
ENGSTRÖM, A.; ENGSTRÖM, P.; TAO, Z.J.; CARLSSON, A.; BENNICH, H. Insect immunity: the primary structure of the antibacterial protein attacin $\mathrm{F}$ and its relation to two native attacins from Hyalophora cecropia. EMBO Journal, v.3, p.2065-2070, 1984a.

ENGSTRÖM, P.; CARLSSON, A.; ENGSTRÖM, A.; TAO, Z.-J.; BENNICH, H.

The antibacterial effect of attacins from the silk moth Hyalophora cecropia is directed against the outer membrane of Escherichia coli. EMBO Journal, v.3, p.3347-3351, 1984b.

ESCANDÓN, A.S.; HAHNE, G. Genotype and composition of culture medium are factors important in the selection of transformaed sunflower (Helianthus annuus) callus. Physiologia Plantarum, v.81, p.367-376, 1991.

FALCO, M.C.; NETO, A.T.; ULIAN, E.C. Transformation and expression of a gene for herbicide resistance in a Brazilian sugarcane. Plant Cell Reports, v.19, p.1188-1194, 2000.

FARIA, L.C.; SEGURA, J. In vitro control of adventitious bud differentiation by inorganic medium components and silver thiosulfate in explants of Passiflora edulis f. flavicarpa Degener. In Vitro Cell Developmental Biology-Plant, v.33, p.209-212, 1997.

FISCHOFF, D.A.; BOWDISH, K.S.; PERLAK, F.J.; MAR-RONE, P.G.; MCCORMICK, S.M.; NIEDERMEYER, J.G.; DEAN, D.A.; KUSANOKRETZMER, K.; MAYER, E.J.; ROCHESTER, D.E.; ROGERS, S.G.;; FRALEY, R.T.; Insect tolerant transgenic tomato plants. Bio/Technology, v.5, p.807-813, 1987.

FLEMING, G.H.; OLIVARES-FUSTER, O.; DEL-BOSCO, S.F.; GROSSER, J.W. An alternative method for the genetic transformation of sweet orange. In Vitro Cell Developmental Biology-Plant, v.36, p.450-455, 2000.

FLORACK, D.; ALLEFS, S.; BOLLEN, R.; BOSCH, D.; VISSER, B.; STIEKEMA, W.. Expression of giant silkmoth cecropin $B$ genes in tobacco. Transgenic Research, v.4, p.132-141, 1995. 
FNP CONSULTORIA \& COMÉRCIO. Agrianual 2002: anuário estatístico da agricultura brasileira. São Paulo, 2002. 536p.

FRALEY, R.T.; ROGERS, S.G.; HORSCH, R.B.; SANDERS, P.R.; FLICK, J.S.; ADAMS, S.P.; BITTNER, M.L.; BRAND, L.A.; FINK, C.L.; FRY, J.S.; GALLUPPI, G.R.; GOLDBERG, S.B.; HOFFMANN, N.L.; WOO, S.C. Expression of bacterial genes in plant cells. Proceedings of the National Academy of Science of USA, v.80, p.4803-4807, 1983.

FUGIMOTO, H.; ITOH, K.; YAMAMOTO, M.; KYOZUKA, J.; SHIMAMOTO, K. Insect resistance rice renerated by introduction of a modified $\delta$-endotoxin gene of Bacillus thuringiensis. Bio/Technology, v.11, p.1151-1155, 1993.

GASPAR, T.; KEVERS, C.; BISBIS, B.; FRANCK, T.; CREVECOEUR, M.; GREPPIN, H.; DOMMES, J. Loss of plant organogenic totipotency in the course of in vitro neoplastic progression. In Vitro Cell Developmental Biology-Plant, v.36, p.171-181, 2000.

GEORGE, E.F. Plant propagation by tissue culture. 2.ed. Edington: Exegetics Limited, 1993. 574p.

GIRI, C.C.; LAXMI, G.V. Production of transgenic rice with agronomically useful genes: an assessment. Biotechnology Advances, v.18, p.653-683, 2000.

GONÇALVES, E.R.; ROSATO, Y.B. Genotypic charachterization of xanthomonad strains isolated from passion fruit plants (Passiflora spp.) and their relatedness to different Xanthomonas species. International Journal of Systematic and Evolutionary Microbiology, v.50, p.811-821, 2000.

GORDON-KAMM, W.; SPENCER, T.; MANGANO, M.L.; ADAMS, T.R.; DAINES, R.J.; TART, W.G.; O'BRIEN, J.V.; CHAMBERS, S.A.; ADAMS, W.R.; WILLETTS, N.G.; RICE, T.B.; MACKEY, C.J.; KRUEGER, R.W.; $\mathrm{KAUSCH}$, A.P.; LEMAUX, P.G. Transformation of maize cells and regeneration of fertile transgenic plants. The Plant Cell, v.2, p.603-618, 1990. 
GUALBERTO, J.M.; LAMATINA, L.; BONNARD, G.; WEIL, J.H.; GRIENENBERGER, J.M. RNA editing in wheat mitochondria results in the conservation of protein sequences. Nature, v.341, p.662-666, 1989.

GUTIERREZ, E.M.A.; LUTH, D.; MOORE, G.A. Factors affecting Agrobacterium-mediated transformation in citrus and production of sour orange (Citrus aurantium L.) plants expressing the coat protein gene of the citrus tristeza virus. Plant Cell Reports, v.16, p.745-753, 1997.

HALDRUP, A.; NOERREMARK, M.; OKKELS, F.T. Plant selection principle based on xylose isomerase. In Vitro Cell Developmental Biology-Plant, v.37, p.114-119, 2001.

HALL, R.M.; DREW, R.A.; HIGGIN, C.M.; DIETZGEN, R.G. Efficient organogenesis of na Australian passionfruit hybrid (Passiflora edulis $\mathrm{x}$ Passiflora edulis var. flavicarpa) suitable for gene delivery. Australian Journal of Botany, v.48, p.673-680, 2000.

HANAHAN, D. Studies on the transformation of Escherichia coli with plasmids. Journal of Molecular Biology, v.166, p.557-580, 1983.

HAUPTMANN, R.M.; VASIL, V.; OZIAS-AKINS, P.; TABAEIZADEH, Z.; ROGERS, S.G.; FRALEY, R.T.; HORSCH, R.B.; VASIL, I.K. Evaluation of selectable markers for obtaining stable transformants in the Gramineae. Plant Physiology, v.86, p.602-606, 1988.

HAYFORD, M.B.; MEDFORD, J.I.; HOFFMAN, N.L.; ROGERS, S.G.; KLEE, H.J. Development of a plant transformation selection system based on expression of genes encoding gentamycin acetyltransferases. Plant Physiology, v.86, p.1216-1222, 1988.

HEDDEN, P.; PROEBSTING, W.M. Genetic analysis of gibberellin biosynthesis.

Plant Physiology, v.119, p.365-370, 1999.

HEDENGREN, M.; BORGE, K.; HULTMARK, D. Expression and evolution of the Drosophila attacin/diptericin gene family. Biochemical and Biophysical Research Communications, v.279, p.574-581, 2000. 
HICKS, G.S. Shoot induction and organogenesis in vitro: a developmental perspective. In Vitro Cell Developmental Biology-Plant, v.30, p.10-15, 1994.

HIGHTOWER, R.; BADEN, C.; PENZES, E.; DUNSMUIR, P. The expression of cecropin peptide in transgenic tobacco does not confer resistance to Pseudomonas syringae pv. tabaci. Plant Cell Reports, v.13, p.295-299, 1994.

HO, C.K.; CHANG, S.H.; TSAY, J.Y.; TSAI, C.J.; CHIANG, V.L.; CHEN, Z.Z. Agrobacterium tumefaciens-mediated transformation of Eucalyptus camaldulensis and production of transgenic plants. Plant Cell Reports, v.17, p.675-680, 1998.

HOBBS, S.L.A.; JACKSON, J.A.; BALISKI, D.S.; DeLONG, C.M.O.; MAHON, J.D. Genotype- and promoter-induced variability in transient $\beta$-glucuronidase expression in pea protoplasts. Plant Cell Reports, v.9, p.17-20, 1990.

HOEKEMA, A.; HIRSCH, P.R.; HOOYKAAS, P.J.J.; SCHILPEROORT, R.A.A binary plant vector strategy based on separation vir and T-region of Agrobacterium tumefaciens Ti-plasmid. Nature, v.303, p.179-180, 1983.

HOFFMANN, J.A.; KAFATOS, F.C.; JANEWAY, C.A.; EZEKOWITZ, A.B. Phylogenetic perspectives in innate immunity. Science, v.248, p.1313-1318, 1999.

HOFFMANN, L.V.; VIEIRA, M.L.C.; Resposta in vitro e suscetibilidade ao Agrobacterium de duas cultivares de Stylosanthes guianensis. Pesquisa Agropecuária Brasileira, v.35, p.733-742, 2000.

HOOD, E.E.; GELVIN, S.B.; MELCHERS, L.S.; HOEKEMA, A. New Agrobacterium helper plasmids for gene transfer into plants. Transgenic Research, v.2, p.208-218, 1993.

HOOLEY, R. Gibberellins: perception, transduction and responses. Plant Molecular Biology, v.26, p.1529-1555, 1994. 
HUANG, Y.; NORDEEN, R.O.; DI, M.; OWENS, L.D.; McBEATH, J.H. Expression of an engineered cecropin gene cassette in transgenic tobacco plants confers disease resistance to Pseudomonas syringae pv. tabaci. Phytopathology, v.87, p.494-499, 1997.

HULTMARK, D. Immune reactions in Drosophila and other insects: a model for innate immunity. Trends in Genetics, v.9, p.178-183, 1993.

HULTMARK, D.; ENGSTRÖM, A.; ANDERSSON, K.; STEINER, H.; BENNICH, H.; BOMAN, H.G. Insect immunity. Attacins, a family of antibacterial proteins from Hyalophora cecropia. EMBO Journal, v.2, p.571-576, 1983.

INOUE, T.; HIGUCHI, M.; HASHIMOTO, Y.; SEKI, M.; KOBAYASHI, M.; KATO, T.; TABATA, S.; SHINOZAKI, K.; KAKIMOTO, T. Identification of CRE1 as a cytokinin receptor from Arabidopsis. Nature, v.409, p.1060-1063, 2001.

JACKSON, S.A.; ZHANG, P.; CHEN, W.P.; PHILLIPS, R.L.; FRIEBE, B.; MUTHUKRISHNAN, S.; GILL, B.S. High-resolution structural analysis of biolistic transgene integration into the genome of wheat. Theoretical and Applied Genetics, v.103, p.56-62, 2001.

JAYNES, J.M.; NAGPALA, P.; DESTEFANO-BELTRAN, L.; HONG-HUNG, J.; KIM, J.; DENNY, T.; CETINER, S. Expression of a cecropin B lytic peptide analogue in transgenic tobacco confers enhanced resistance to bacterial wilt caused by Pseudomonas solanacearum. Plant Science, v.8, p.43-53, 1993. JAYNES, J.M.; XANTHOPOULOS, K.G.; DESTÉFANO-BELTRÁN, L.; DODDS, J.H. Increasing bacterial disease resistance in plants utilizing antibacterial genes from insects. Bioessays, v.6, p.263-270, 1987.

JEFFERSON, R.A.; KAVANAGH, T.A.; BEVAN, M.W. GUS fusion: the $\beta$ glucuronidase as sensitive and versatile gene fusion marker in higher plants. EMBO Journal, v.6, p.3301-3307, 1987.

JOBLING, S.A.; GEHRKE, L. Enhanced translation of chimaeric messenger RNAs containing a plant viral untranslated leader sequence. Nature, v.325, p.622-625, 1987. 
JOERSBO, M. Advances in the selection of transgenic plants using nonantibiotic marker genes. Physiologia Plantarum, v.111, p.269-272, 2001.

JOHNSON, P.R.; ECKER, J.R. The ethylene gas signal transduction pathway: a molecular perspective. Annual Review of Genetics, v.32, p.227-254, 1998. KAKIMOTO, T. CKI1, a histidine kinase homolog implicated in cytokinin signal transduction. Science, v.274, p.982-985, 1996.

KANG, D.; LUNDSTRÖM, A.; STEINER, H. Trichoplusia ni attacin A, a differentially displayed insect gene coding for an antibacterial protein. Gene, v.174, p.245-249, 1996.

KANTHARAJAH, A.S.; DODD, W.A. In vitro micropropagation of Passiflora edulis (Purple passion fruit). Annals of Botany, v.65, p.337-339, 1990.

KAPAUN, J.A.; CHENG, Z-M. Aminoglycoside antibiotics inhibit shoot regeneration from siberian elm leaf explants. HortScience, v.34, p.727-729, 1999.

KARNOVSKY, M.J. A formaldehyde-glutaraldehyde fixative of high osmolarity for use electron microscopy. Journal of Cell Biology, v.27, p.137-138, 1965.

KAWATA, K.; USHIDA, C.; KAWAI, F.; KANAMORI, M.; KURIYAMA, A. Micropropagation of passion fruit from subcultured multiple shoot primordia. Journal of Plant Physiology, v.147, p.281-284, 1995.

KIDWELL, K. Lateral gene transfer in natural populations of eukaryotes. Annual Review of Genetics, v.27, p.235-356, 1993.

KIEBER, J. The ethylene response pathway in Arabidopsis. Annual Review of Plant Physiology Plant Molecular Biology, v.48, p.277-296, 1997.

KIKKERT, J. Biolistic ${ }^{\circledR}$ PDS-1000/HE device. Plant Cell, Tissue and Organ Culture, v.33, p.221-226, 1993.

KLEIN, T.M.; WOLF, E.D.; WU, R.; SANFORD, J.C. High velocity microprojectiles for delivering nucleic acids into living cells. Nature, v.327, p.70-73, 1987. 
KO, K.; NORELLI, J.L.; REYNOIRD, J-P; BORESJZA-WYSOCKA, E.; BROWN, S.K.; ALDWINCKLE, H.S. Effect of untranslated leader sequence of AMV RNA 4 and signal peptide of pathogenesis-related protein $1 \mathrm{~b}$ on attacin gene expression, and resistance to fire blight in transgenic apple. Biotechnology Letters, v.22, p.373-381, 2000.

KOCKUM, K.; FAYE, I.; HOFSTEN, P.V.; LEE, J. Y.; XANTHOPOULOS, K.G.; BOMAN, H.G. Insect immunity. Isolation and sequence of two cDNA from Hyalophora cecropia. EMBO Journal, v.3, p.2071-2075, 1984.

KOHLI, A.; GAHAKWA, D.; VAIN, P.; LAURIE, D.A.; CHRISTOU, P. Transgene expression in rice engineered though particle bombardment: molecular factors controlling stable expression and transgene silencing. Planta, v.208, p.88-97, 1999.

KOHLI, A.; LEECH, M.; VAIN, P.; LAURIE, D.A.; CHRISTOU, P. Transgene integration in rice engineered through direct DNA transfer supports a twophase integration mechanism mediated by the establishment of integration hot spots. Proceedings of the National Academy of Sciences of USA, v.95, p.7203-7208, 1998.

KONONOV, M.E.; BASSUNER, B.; GELVIN, S.B. Integration of T-DNA binary vector 'backbone' sequences into the tobacco genome: Evidence for multiple complex patterns of integration. Plant Journal, v.11, p.945-957, 1997.

KORS, F.T. M. Antibiotics, mode of action, spectrum, resistance, solubility, sterilization, stability. Haarlem: Duchefa Biochemicals B. V., 1991. 352p.

KOSUGI, S.; OHASHI, Y.; NAKAJIMA, K.; ARAI, Y.; An improved assay for $\beta$ glucuronidase in transformed cells: methanol almost completely suppresses a putative endogenous $\beta$-glucuronidase activity. Plant Science, v.70, p.133140, 1990.

KOZIEL, M.G.; BELAND, G.L.; BOWMAN, C. Field performance of elite transgenic maize plants expressing an insecticidal protein derived from Bacillus thuringiensis. Bio/Tecnology, v.11, p.194-200, 1993. 
KURODA, N.H. Avaliação do comportamento quanto à resistência de espécies e progênies de maracujazeiro a Xanthomonas passiflorae Pereira. Jaboticabal, 1981. 47p. Monografia (Graduação) - Faculdade de Ciências Agrárias e Veterinárias, Universidade Estadual Paulista "Julio de Mesquita Filho".

LAZZARO, B.P.; CLARK, A.G. Evidence for recurrent paralogous gene conversion and exceptional allelic divergence in the attacin genes of Drosophila melanogaster. Genetics, v.159, p.659-671, 2001

LESSARD, P.A.; KULAVEERASINGAM, H.; YORK, G.M.; STRONG, A.; SINSKEY, A.J. Manipulation gene expression for the metabolic engineering of plants. Metabolic Engineering, v.4, p.67-79, 2002.

LOPES, S.C. Citogenética do maracujá, Passiflora spp. In: SÃO JOSÉ, A.R. A cultura do maracujá no Brasil. Jaboticabal: Funep, 1991. p.201-209.

MACHADO, M.L.C.; MACHADO, A.C.; HANZER, V.; WEISS, H.; REGNER, F.; STEINKELLNER, H.; MATTANOVICH, D.; PLAIL, R.; KNAPP, E.; KALTHOFF, B.; KATINGER, H. Regeneration of transgenic plants of Prunus armeniaca containing the coat protein gene of Plum Pox Virus. Plant Cell Reports, v.11, p.25-29, 1992

MANDERS, G.; OTONI, W.C.; d'UTRA VAZ, F.B.; BLACKHALL, N.W.; POWER, J.B.; DAVEY, M.R. Transformation of passionfruit (Passiflora edulis $\mathrm{fv}$ flavicarpa Degener.) using Agrobacterium tumefaciens. Plant Cell Reports, v.13, p.697-702, 1994.

MANICA, I. Maracujá: temas selecionados (1): melhoramento, morte prematura, polinização, taxonomia. Porto Alegre: Cinco Continentes, 1997. p.25-46.

MANTE, S.; MORGENS, P.H.; SCORZA, R.; CORDTS, J.M.; CALLAHAM, A.M. Agrobacterium-mediated transformation of plum (Prunus domestica L.) hypocotyl slices and regeneration of transgenic plants. Bio/Technology, v.9, p.853-857, 1991. 
MATSUMOTO, N.; OKADA, M.; TAKAHASHI, H.; MING, Q.X.; NAKAJIMA, Y.; NAKANISHI, Y.; KOMANO, H.; NATORI, S. Molecular cloning of a cDNA and assignment of the C-terminal of sarcotoxina IA, a potent antibacterial protein of Sarcophaga peregrina. Biochemical Journal, v.239, p.717-722, 1986.

MAY, G.D.; AFZA, R.; MASON, H.S.; WIEKO, A.; NOVAK, F.J.; ARNTZEN, C.J. Generation of transgenic banana (Musa acuminata) plants via Agrobacterium-mediated transformation. Bio/Technology, v.13, p.486-492, 1995.

McCABE, D.E.; SWAIN, W.F.; MARTINELL, B.J.; CHRISTOU, P. Stable transformation of soybean (Glycine max) by particle acceleration. Bio/Technology, v.6, p.923-926, 1988.

MELETTI, L.M.; SANTOS, R.R.; MINAMI, K. Melhoramento do maracujazeiroamarelo: obtenção do cultivar 'composto IAC-27'. Scientia Agricola, v.57, p.491-498, 2000.

MELETTI, L.M.M. Situação regional da cultura do maracujá sudeste - Estado de São Paulo. In: REUNIÃO TÉCNICA DE PESQUISA EM MARACUJAZEIRO, Londrina, 1999. Resumos. Londrina: IAPAR/SBF, 1999. p.32.

MELETTI, L.M.M.; MAIA, M.L. Maracujá: produção e comercialização. Campinas: IAC, 1999. 64p. (IAC Boletim Técnico, 181)

MELO, K.T.; MANICA, I.; JUNQUEIRA, N.T.V. Produtividade de seis cultivares de maracujazeiro-azedo durante três anos em Vargem Bonita, DF. Pesquisa Agropecuária Brasileira, v.36, p.1117-1125, 2001.

MITSUHARA, I.; MATSUFURU, H.; OHSHIMA, M.; KAKU, H.; NAKAJIMA, Y.; MURAI, N.; NATORI, S.; OHASHI, Y. Induced expression of sarcotoxin IA enhanced host resistance against both bacterial and fungal pathogens in transgenic tobacco. Molecular Plant-Microbe Interactions, v.13, p.860$868,2000$. 
MITSUHARA, I.; NAKAJIMA, Y.; NATORI, S.; MITSUOKA, T.; OHASHI, Y. In vitro growth inhibition of human intestinal bacteria by sarcotoxin IA, an insect bactericidal peptide. Biotechnology Letters, v.23, p.569-573, 2001.

MITSUHARA, I.; UGAKI, M.; HIROCHIKA, H.; OHSHIMA, M.; MURAKAMI, T.; GOTOH, Y.; KATAYOSE, Y.; NAKAMURA, S.; HONKURA, R.; NISHIMIYA, S.; UENO, K.; MOCHIZUKI, A.; TANIMOTO, H.; TSUGAWA, H.; OTSUKI, Y.; OHASHI, Y. Efficient promotor cassettes for enhanced expression of foreign genes in dicotyledonous and monocotyledonous plants. Plant Cell Physiology, v.37, p.49-59, 1996.

MOK, D.W.S.; MOK, M.C. Cytokinin metabolism and action. Annual Review of Plant Physiology Plant Molecular Biology, v.52, p.89-118, 2001.

MONTEIRO, A.C.B. de A.; NAKAZAWA, G.T.; MENDES, B.M.J.; RODRIGUEZ, A.P.M. Regneração in vitro de Passiflora suberosa a partir de discos foliares. Scientia Agricola, v.57, p.571-573, 2000b.

MONTEIRO, A.C.B. de A.; HIGASHI, E.N.; GONÇALVES, A.N.; RODRIGUEZ, A.P.M. A novel approach for the definition of the inorganic medium components for micropropagation of yellow passionfruit (Passiflora edulis Sims f. flavicarpa Deg.). In Vitro Cell Developmental Biology-Plant, v.36, p.527-531, 2000a.

MORAN ROBLES, J.M. Multiplication végétative in vitro des bourgeons axillaires de Passiflora edulis var. flavicarpa Degener et de P. molissima Bailey. Fruits, v.33, p.693-699, 1978.

MORAN ROBLES, J.M. Potentiel morphogénétique des entrenoeuds de Passiflora edulis var. flavicarpa Deg. et $P$. mollissima Bailey en culture in vitro. Turialba, v.29, p.224-228, 1979.

MOURAD-AGHA, N.; DEXHEIMER, J. Étude ultrastructurale de la différentiotion des éléments conducteurs dans une culture de tissue de Passiflora quadragularis L. I. Cals cultivés à l'obscurité. Cytologia, v.44, p.615-631, 1979. 
MOURGUES, F.; BRISSET, M.N.; CHEVREAU, E. Strategies to improve plant resistance to bacterial disease through genetic engineering. Trends in Biotechnology, v.16, p.203-210, 1998.

MUKHOPADHYAY, A.; ARUMUGAM, N.; NANDAKUMAR, P.B.A.; PRADHAN, A.K.; GUPTA, V.; PENTAL, D. Agrobacterium-mediated genetic transformation of oilseed Brassica campestris: transformation frequency is strongly influenced by mode of shoot regeneration. Plant Cell Reports, v.11, p.506-513, 1992.

MULLINS, M.G.; TANG, F.C.A.; FACCIOTTI, D. Agrobacterium-mediated genetic transformation of grapevines: transgenic plants of Vitis rupestris Scheele and buds of Vitis vinifera L. Bio/Technology, v.8, p.1041-1045, 1990.

MURAKAMI, T.; ANZAI, H.; IMAI, S.; SATOH, A.; NAGAOKA, D.; THOMPSON, C.J. The bialaphos biosynthetic genes of Streptomyces hygroscopicus: molecular cloning and characterization of the gene cluster. Molecular and General Genetics, v.205, p.42-50, 1986.

MURASHIGE, T.; SKOOG, F. A revised medium for rapid growth and bioassays with tobacco tissue cultures. Physiologia Plantarum, v.15, p.473-497, 1962.

MURRAY, M.G.; THOMPSON, W.F. Rapid isolation of high molecular weight plant DNA. Nucleic Acids Research, v.8, p.1134-1137, 1980.

NAKAJIMA, Y.; QU, X.M.; NATORI, S. Interaction between liposomes and sarcotoxin IA, a potent antibacterial protein of Sarcophaga peregrina (flesh fly). Journal of Biological Chemistry, v.262, p.1665-1669, 1987.

NAKATANI, A.K. Diversidade genética de Xanthomonas campestris pv. passiflorae e sensibilidade a produtos químicos. Piracicaba, 2001. 61p. Dissertação (M.S.) - Escola Superior de Agricultura "Luiz de Queiroz", Universidade de São Paulo. 
NANDADEVA, Y.L.; LUPI, C.G.; MEYER, C.S.; DEVI, P.S.; PORTRYKUS, I.; BILANG, R. Microprojectile-mediated transient and integrative transformation of rice embryogenic suspension cells: effects of osmotic cell conditioning and of the physical configuration of plasmid DNA. Plant Cell Reports, v.18, p.500-504, 1999.

NAP, J.P.; BIJVOET, J.; STIEKEMA, W. Biosafety of kanamycin-resistant transgenic plants. Transgenic Research, v.1, p.239-249, 1992.

NETO, J.R., SUGIMORI, M.H., MALAVOLTA, Jr.V.A. Infecção natural em Passiflora alata Ait, por Xanthomonas campestris pv. passiflorae. Summa Phytopathologica, v.10, p.50, 1984.

NORDEEN, R.D.; SINDEN, S.L.; JAYNES, J.M.; OWENS, L.D. Activity of cecropin SB37 against protoplasts from several plant species and their bacterial pathogens. Plant Science, v.82, p.101-107, 1992.

NORELLI, J.; ALDWINCKLE, H. Increasing the fire blight resistance of apple by transformation with genes encoding antibacterial proteins. Acta Horticulturae, v.338, p.385-386, 1993.

NORELLI, J.L.; ALDWINCKLE, H.S.; DESTEFANO-BELTRAN, L.; JAYNES, J.M. Transgenic "Malling 26" apple expressing the attacin E gene has increased resistance to Erwinia amylovora. Euphytica, v.77, p.123-128, 1994.

OKADA, M.; NATORI, S. Mode of action of a bactericidal protein induced in the haemolimph of Sarcophaga peregrina (flesh-fly) larvae. Biochemical Journal, v.222, p.119-124, 1984.

OKAMOTO, M.; MIOTSUHARA, I.; OSHIMA, M.; NATORI, S.; OHASHI, Y. Enhanced expression of an antimicrobial peptide sarcotoxin IA by GUS fusion in transgenic tobacco plants. Plant Cell Phsiology, v.39, p.57-63, 1998. 
OLIVEIRA, G.H.N.; SUDO, S.; SILVA, J.R.; KIMURA, O. Ocorrência de Xanthomonas campestris pv. passiflorae infectando vascularmente plantas de maracujazeiro ( $P$. edulis f. flavicarpa). Fitopatologia Brasileira, v.13, p.107, 1988.

OLIVEIRA, J.C. Melhoramento genético. In: RUGGIERO, C. (Ed.). Cultura do maracujazeiro. Ribeirão Preto: Legis Summa, 1987. p.218-246.

OLIVEIRA, J.C.; FERREIRA, F.R. Melhoramento genético do maracujazeiro. In: SÃO JOSÉ, A.R.; FERREIRA, F.R.; VAZ, R.L. (Ed.). A cultura do maracujá no Brasil. Jaboticabal: FUNEP, 1991. p.211-239.

OSHIMA, M.; MITSUHARA, I.; OKAMOTO, M.; SAWANO, S.; NISHIYAMA, K.; KAKU, H.; NATORI, S.; OHASHI, Y. Enhanced resistance to bacterial disease of transgenic tobacco plants overexpressing sarcotoxina IA, a bactericidal peptide of insect. Journal of Biochemistry, v.125, p.431-435, 1999.

OTAHOLA, V. Regeneración de plantas de parchita (Passiflora edulis $\mathrm{f}$. flavicarpa) a partir del cultivo in vitro de discos de hojas. Bioagro, v.12, p.71-74, 2000.

OTONI, W.C. Hibridação e embriogênese somáticas e transformação genética em espécies de Passiflora. Viçosa, 1995. 198p. Tese (Doutorado) Universidade Federal de Viçosa.

OTONI, W.C.; CASALI, V.W.D.; POWER, J.B.; DAVEY, M.R. Expressão transitória do gene gus em maracujazeiro (Passiflora giberti N. E. Brown) mediada pelo bombardeamento de partículas. Revista Ceres, v.43, p.326335, 1996.

OZAWA, S.; YASUTANI, I.; FUKUDA, H.; KOMAMINE, A.; SUGIYAMA, M. Organogenic responses in tissue culture of srd mutants of Arabidopsis thaliana. Development, v.125, p.135-142, 1998.

PASSOS, I.R.S. Comportamento in vitro em Vitis spp e em Passiflora nitida H. B. K. Piracicaba, 1999, 112p. Tese (Doutorado) - Escola Superior de Agricultura "Luiz de Queiroz", Universidade de São Paulo. 
PAWLOWSKI, W.P.; SOMERS, D.A. Transgenic DNA integrated into the oat genome is frequently interspersed by host DNA. Proceedings of the National Academy of Sciences of USA, v.95, p.12106-12110, 1998.

PEFEROEN, M. Engineering of insect-resistant plants with Bacillus thuringiensis crystal protein genes. In: GATEHOUSE, A. M.R.; HILDER, V.A.; BOULTER, D. (Ed.). Plant genetic manipulation for crop protection. Wallingford: CAB International, 1992. p.237-269 (Biotechnology in Agriculture, 7)

PEÑA, L.; CERVERA, M.; JUÁREZ, J.; NAVARRO, A.; PINA, J.A.; DURÁNVILA, N.; NAVARRO, L. Agrobacterium-mediated transformation of sweet orange and regeneration of transgenic plants. Plant Cell Reports, v.14, p.616-619, 1995a.

PEÑA, L.; CERVERA, M.; JUÁREZ, J.; ORTEGA, C.; PINA, J.A.; DURÁN-VILA, N.; NAVARRO, L. High efficiency Agrobacterium-mediated transformation and regeneration of citrus. Plant Science, v.104, p.183-191, 1995b.

PENG, J.; KONONOWICZ, H.; HODGES, T.K. Transgenic indica rice plants. Theoretical and Applied Genetics, v.83, p.855-863, 1992.

PEREIRA, A.L.G. Uma nova doença bacteriana do maracujá (Passiflora edulis, Sims) causada por Xanthomonas passiflorae n.sp. Arquivo do Instituto Biológico São Paulo, v.36, p.163-174, 1969.

PERES, L.E.P. Bases fisiológicas e genéticas da regeneração de plantas in vitro. Biotecnologia Ciência \& Desenvolvimento, v.4, p.44-48, 2002.

PERES, L.E.P.; KERBAUY, G.B. High cytokinin accumulation following root tip excision changes the endogenous auxin-to-cytokinin ratio during root-toshoot conversion in Catasetum fimbriatum Lindl. (Orchidaceae). Plant Cell Reports, v.18, p.1002-1006, 1999.

PÉREZ-MOLPHE-BALCH, E.; OCHOA-ALEJO, N. Regeneration of transgenic plants of Mexican lime from Agrobacterium rhizogenes-transformed tissues. Plant Cell Reports, v.17, p.591-596,1998 
PERL, A.; LOTAN, O.; ABU-ABIED, M.; HOLLAND, D. Establishment of an Agrobacterium-mediated transformation system for grape (Vistis vinifera L.): the role of antioxidants during grape-Agrobacterium interactions. Nature Biotechnology, v.14, p.624-628, 1996.

PERLAK, F.J.; DEATON, R.W.; ARMSTRONG, T.O.; FUCHS, R.L.; SIMS, S.R.; GREENPLATE, J.T.; FISCHOFF, D.A. Insect resistant cotton plants. Bio/Technology, v.8, p.939-943, 1990.

PHATAK, S.C.; JAWORSKI, C.A.; LIPTAY, A. Flowering and adventitious root growth of tomato cultivars as influenced by ethephon. HortScience, v.16, p.181-182, 1981.

PINK, D.; PUDDEPHAT, I. Deployment of disease resistance genes by plant transformation - a 'mix and match' approach. Trends in Plant Science, v.4, p.71-75, 1999.

PITTS, R.J.; CERNAC, A.; ESTELLE, M. Auxin and ethylene promote root hair elongation in Arabidopsis. Plant Journal, v.16, p.553-560, 1999.

POTRYKUS, I. Gene transfer to plants: assessment and perspectives. Physiologia Plantarum, v.79, p.125-134, 1990.

POTRYKUS, I.; SAUL, M.W.; PETRUSKA, J.; PASZKOWSKI, J.; SHILLITO, R.D. Direct gene transfer to cells of a graminaceous monocot. Molecular and General Genetics, v.199, p.183-188, 1985.

QUECINI, V.M. Transferência direta de genes para plantas de Stylosanthes guianensis (Aubl.) Sw. Piracicaba, 1999. 172p. Tese (Doutorado) - Escola Superior de Agricultura "Luiz de Queiroz", Universidade de São Paulo.

QUECINI, V.M.; VIEIRA, M.L.C. Plantas transgênicas. In: SERAFINI, L.A.; BARROS, N.M. de; AZEVEDO, J.L. de. (Coord.). Biotecnologia na agricultura e na agroindústria. Guaíba: Agropecuária, 2001. cap.8, p.279331. 
REED, J.; PRIVALLE, L.; POWELL, M.L.; MEGHJI, M.; DAWSON, J.; DUNDER, E.; SUTTIE, J.; WENCK, A.; LAUNIS, K.; KRAMER, C.; CHANG, Y-F.; HANSEN, G.; WRIGHT, M. Phosphomannose isomerase: an efficient selectable marker for plant transformation. In Vitro Cell Developmental Biology-Plant, v.37, p.127-132, 2001.

REED, W.A.; ELZER, P.H.; ENRIGHT, F.M.; JAYNES, J.M.; MORREY, J.D.; WHITE, K.L. Interleukin 2 promoter/enhancer controlled expression of a synthetic cecropin-class lytic peptide in transgenic mice and subsequent resistance to Bruccella abortus, Transgenic Research, v.6, p.337-347, 1997.

REIS, L.B. dos. Morfogênese in vitro de maracujá-amarelo (Passiflora edulis $\mathrm{f}$. flavicarpa Degener) associada ao etileno e a agentes gelificantes. Viçosa, 2001. 89p. Dissertação (M.S.) - Universidade Federal de Viçosa.

REYNOIRD, J.P.; MOURGUES, F.; NORELLI, J.; ALDWINCKLE, H.S.; BRISSET, M.N.; CHEVREAU, E. First evidence for improved resistance to fire blight in transgenic pear expressing the attacin $E$ gene from Hyalophora cecropia. Plant Science, v.149, p.23-31, 1999.

ROBBINS, J.A.; KAYS, S.J.; DIRR, M.A. Enhanced rooting of wounded mung bean cuttings by wounding and ethephon. Journal of de American Society for Horticultural Science, v.108, p.325-329, 1983.

ROGERS, H.J.; PARKES, H.C. Transgenic plants and the environment. Journal of Experimental Botany, v.46, p.467-488, 1995.

ROMANO, A.; RAEMAKERS, K.; VISSER, R.; MOOIBROEK, H. Transformation of potato (Solanum tuberosum) using particle bombardment. Plant Cell Reports, v.20, p.198-204, 2001.

RUGGIERO, C.; SÃO JOSÉ, A.R.; VOLPE, C.A.; OLIVEIRA, J.C. de; DURIGAN, J.F.; BAUMGARTNER, J.G.; SILVA, J.R.; NAKAMURA, K.; FERREIRA, M.E.; KAVATI, R.; PEREIRA, V. de P. Maracujá para exportação: aspectos técnicos da produção. Brasília: MAARA/EMBRAPA, SPI, 1996. 64p. (Série Publicações Técnicas FRUPEX, 19) 
SÁGI, L.; PANIS, B.; REMY, S.; SCHOOFS, H.; DE SMET, K.; SWENNEN, R.; CAMMUE, B.P.A. Genetic transformation of banana and plantain (Musa spp.) via particle bombardment. Bio/Technology, v.13, p.481-485, 1995a.

SÁGI, L.; REMY, S.; VERELST, B.; PANIS, B.; CAMMUE, B.P.A.; VOLCKAERT, G.; SWENNEN, R. Transient gene expression in transformed banana (Musa cv. Bluggoe) protoplasts and embryogenic cell suspensions. Euphytica, v.85, p.89-95, 1995b.

SAKAI, W.S. Simple method form different staining of parafin embedded plant material using toluidine blue O. Stain Technology, v.48, p.247-249, 1973.

SAMBROOK, J.; FRITSCH, E.E.; MANIATIS, T.I. Molecular cloning: a laboratory manual. 2.ed. New York: Cold Spring Harbor Laboratory Press, 1989. 543p.

SANFORD, J.C. The biolistic plant transformation. Physiologia Plantarum, v.79, p.206-209, 1990.

SANFORD, J.C.; DEVIT, M.J.; RUSSELL, J.A.; SMITH, F.D.; HARPENDING, PR.; ROY, M.K.; JOHNSTON, S.A. An improved, helium-driven biolistic device. Technique, v.3, p.3-16, 1991.

SANFORD, J.C.; SMITH, F.D.; RUSSELL; J.A. Optimizing the biolistic process for different biological applications. Methods in Enzymology, v.217, p.483509, 1993.

SCHLÜTER, K.; FÜTTERE, J.; POTRYKUS, I. "Horizontal" gene transfer from a transgenic potato line to a bacterial pathogen (Erwinia chrysanthemi) occurs - if at all - at an extremely low frequency. Bio/Tehnology, v.13, p.10941098, 1995.

SCHMIDT, R.; WILLMITZER, L. High efficiency Agrobacterium tumefaciens mediated leaf disc transformation of Arabidopsis thaliana leaf and cotyledons explants. Plant Cell Reports, v.7, p.583-586, 1988.

SCHULZ, A.; WENGENMAYER, F.; GOODMAN, H. M. Genetic engineering of herbicide resistance in higher plants. Critical Reviews in Plant Science, v.9, p.1-15, 1990. 
SCORZA, R.; CALLAHAN, A.; LEVY, L.; DAMSTEEGT, V.; RAVELONANDRO, M. Transferring potyvirus coat protein genes through hybridization of transgenic plants to produce plum pox virus resistant plums (Prunus domestica) L. Acta Horticulturae, v.472, p.421-425, 1998.

SCORZA, R.; JANICK, J. In vitro flowering of Passiflora suberosa L. Journal of de American Society for Horticultural Science, v.105, p.892-897, 1980.

SCORZA, R.; RAVELONANDRO, M.; CALLAHAN, A.M.; CORDTS, J.M.; FUCHS, M.; DUNEZ, J. Transgenic plums (Prunus domestica L.) express the plum pox virus coat protein gene. Plant Cell Reports, v.14, p.18-22, 1994.

SHELP, B.J.; SWANTON, C.J.; HALL, J.C. Glufosinate (phosphinothricin) mobility in young soybean shoots. Journal of Plant Physiology, v.139, p.626-628, 1992.

SILVA, M.B. Transformação genética de maracujá-amarelo (Passiflora edulis $\mathrm{f}$. flavicarpa Degener) mediada por Agrobacterium tumefaciens. Viçosa, 1998. 45p. Dissertação (M.S.) - Universidade Federal de Viçosa.

SILVA-FILHO, M.C.; FALCO, M.C. Plantas transgênicas no melhoramento. In: NASS, L.L.; VALOIS, A.C.C.; MELO, I.S. de; VALADARES-INGLIS, M.C. Recursos genéticos \& melhoramento. Rondonópolis: Fundação MT, 2001. p.1011-1056.

SKOOG, F.; MILLER, C.O. Chemical regulation of growth and organ formation in plant tissues cultured in vitro. Symposium Society Experimental Biology, v.11, p.118-130, 1957.

SMIGOCKI, A.C.; HAMMERSCHLAG, F.A. Regeneration of plants from peach embryo cells infected with a shooty mutant strain of Agrobacterium. Journal of the American Society for Horticultural Science, v.116, p.1092-1097, 1991.

SMITH, F.D.; JOFRE-GARFIAS, A.; SANFORD, J.C. Transformation of bean apical dome cells by microparticle bombardment. Phytopathology, v.82, p.1167-1168, 1992. 
SMITH, N.; KILPATRICK, J.B.; WHITELAM, G.C. Superfluous transgene integration in plants. Critical Reviews in Plant Science, v.20, p.215-249, 2001.

SRIPAORAYA, S.; MARCHANT, R.; POWER, J.B.; DAVEY, M.R. Herbicidetolerant transgenic pineapple (Ananas comosus) produced by microprojectile bombardment. Annals of Botany, v.88, p.597-603, 2001.

STASKAWICZ, B.J.; MUDGETT, M.B.; DANGL, J.L.; GALAN, J.E. Common and contrasting themes of plant and animal diseases. Science, v.292, p.22852289, 2001.

STEWART, C.N.; ADANG, M.J.; ALL, J.N.; RAYMER, P.L.; RAMACHANDRAM, S.; PARROTT, W.A. Insect control and dosage effects in transgenic canola containing a synthetic Bacillus thuringiensis crylAc gene. Plant Physiology, v.112, p.115-120, 1996.

SUGIYAMA, M. Genetic analysis of plant morphogenesis in vitro. International Review of Cytology, v.196, p.67-84, 2000.

SUN, S.C; LINDSTRÖM, I.; LEE, J.Y.; FAYE, I. Structure and expression of the attacin genes in Hyalophora cecropia. European Journal of Biochemistry, v.196, p.247-254, 1991.

SWAIN, S.M.; OLSZEWSKI, N.E. Genetic analysis of gibberellin signal transduction. Plant Physiology, v.112, p.11-17, 1996.

TACHIBANA, K.; WATANABE, T.; SEKIZAWA, Y.; TAKEMATSU, T. Accumulation of ammonia in plants treated with bialaphos. Journal of Pesticide Science, v.11, p.33-37, 1986b.

TACHIBANA, K.; WATANABE, T.; SEKIZAWA, Y.; TAKEMATSU, T. Inhibition of glutamine synthetase and quantitative changes of free amino acids in shoots of bialaphos-treated Japanese barnyard millet. Journal of Pesticide Science, v.11, p.27-31, 1986a.

TAKANO, M.; EGAWA, H.; IKEDA, J.E.; WADASA, K. Structure of integration sites in transgenic rice. Plant Journal, v.11, p.353-361, 1997. 
TAKATSU, A. Classificação atual de bactérias fitopatogênicas. Revisão Anual de Patologia de Plantas, v.8, p.93-120, 2000.

TEIXEIRA, C.G. Cultura. In: TEIXEIRA, C. G. (Ed.). Maracujá: cultura, matéria prima, processamento e aspectos econômicos. Campinas: ITAL, 1994. p.1142. (Série Frutas Tropicais, 9)

THOMPSON, C.J.; RAO MOVVA, N.; TIZARD, R.; CRAMERI, R.; DAVIES, J. E.; LAUWEREYS, M.; BOTTERMAN, J. Characterization of the herbicideresistant bar gene from Streptomyces hygroscopicus. EMBO Journal, v.6, p.2519-2523, 1987.

TIMMERMANS, M.C.P.; MALIGA, P.; VIEIRA, J.; MESSING, J. The pFF plasmids: cassettes utilising CaMV sequences for expression of foreign genes in plants. Journal of Biotechnology, v.14, p.333-344, 1990.

TORRES, A.C.; CALDAS, L.S. Técnicas e aplicações da cultura de tecidos de plantas. Brasília: ABCTP/EMBRAPA-CNPH, 1990. 433p.

TORRES, F.J.; PONTE, J. Estudo sobre o controle da bacteriose ou "morte precoce" (Xanthomonas campestris pv. passiflorae) do maracujá amarelo (Passiflora edulis f. flavicarpa). Fitopatologia Brasileira, v.19, p.34-38, 1994.

UEGUCHI, C.; SATO, S.; KATO, T.; TABATA, S. The AHK4 gene involved in the cytokinin-signaling pathway as a direct receptor molecule in Arabidopsis thaliana. Plant Cell Physiology, v.42, p.751-755, 2001.

VALVEKENS, D.; MVAN MONTAGU, M.; VAN LIJSEBETTENS, M. Agrobacterium tumefaciens-mediated transformation of Arabidopsis thaliana root explants by using kanamycin selection. Proceedings of the National Academy of Sciences of USA, v.85, p.5536-5540, 1988.

VAN DEN ELZEN, P.J.M; TOWNSEND, J.; LEE, K. Y.; BEDBROOK, J.R.A. Chimaeric hygromycin resistance gene as a selectable marker in plant cells. Plant Molecular Biology, v.5, p.299-305, 1985.

VANDERPLANK, J. Passion flowers. London: Cambridge Press, 1996. 224p. 
VASIL, K.I.; THORPE, T.A. Plant cell and tissue culture. London: Kluwer Academic Publishers, 1994. 593p.

VIEIRA, M.L.C. Hibridação somática em plantas. Biotecnologia Ciência \& Desenvolvimento, v.3, p.36-40, 1997.

WALDRON, C.; MURPHY, E.B.; ROBERTS, J.L.; GUSTAFSON, G.D.; ARMOUR, S.L.; MALCOLM, S.K. Resistance to hygromycin B, a new marker for plant transformation studies. Plant Molecular Biology, v.5, p.103-108, 1985.

WEIDE, R.; KOORNEEF, M.; ZABEL, P.A. Simple, nondestructive spraying assay for the detection of an active kanamycin resistance gene in transgenic tomato plants. Theoretical and Applied Genetics, v.78, p.169-172, 1989.

WELANDER, M.; MAHESWARAN, G. Shoot regeneration from leaf explants of dwarfing apple rootstocks. Journal of Plant Physiology, v.140, p.223-228, 1992.

WENCK, A.; CZAKO, M.; KANEVSKI, I.; MARTON, L. Frequent collinear long transfer of DNA inclusive of the whole binary vector during Agrobacteriummediated transformation. Plant Molecular Biology, v.34, p.913-922, 1997.

WENDLAND, A. Avaliação de espécies de maracujazeiro (Passiflora spp.) à bacteriose e caracterização de Xanthonomas sp. pv. passiflorae. Londrina, 1997. 87p. Monografia (Graduação) - Universidade Estadual de Londrina.

WILMINK, A.; DONS, J.J.M. Selective agents and marker genes for use in transformation of monocotyledonous plants. Plant Molecular Biology Reporter, v.11, p.165-185, 1993.

WINKS, C.W.; MENZEL, C.M.; SIMPSON, D.R. Passionfruit in Queensland 2. Botany and Cultivars. Queensland Agricultural Journal, v.114, p.217-224, 1988.

WITRZENS, B.; BRETTELL, R.; MURRAY, F.; McELROY, D.; LI, Z.; DENNIS, E. Comparison of three selectable marker genes for transformation of wheat by microprojectile bombardment. Australian Journal of Plant Physiology, v.25, p.39-44, 1998. 
WOHLLEBEN, W.; ARNOLD, W.; BROER, I.; HILLEMANN, D.; STRAUCH, E.; PÜHLER, A. Nucleotide sequence of the phosphinothricin-N-acetyltransferase gene from Streptomyces viridochromogenes Tü494 and its expression in Nicotiana tabacum. Gene, v.70, p.25-37, 1988.

WRIGHT, M.; DAWSON, J.; DUNDER, E.; SUTTIE, J.; REED, J.; KRAMER, C.; CHANG, Y.; NOVITZKY, R.; WANG, H.; ARTIM-MOORE, L. Efficient biolistic transformation of maize (Zea mays L.) and wheat (Triticum aestivum L.) using the phosphomannose isomerase gene, pmi, as the selectable marker. Plant Cell Reports, v.20, p.429-436, 2001.

XIA, L.Q.; GUO, S.D. Integration and inheritance stability of foreign Bt toxin gene in the bivalent insect-resistant transgenic cotton plants. Chinese Science Bulletin, v.46, p.1372-1375, 2001.

YAMASHIRO, T. Doenças do maracujazeiro. In: RUGGIERO, C. (Ed.). Cultura do maracujazeiro. Jaboticabal: FCAV-UNESP, 1980. p.95-102.

YAMASHIRO, T. Principais doenças do maracujazeiro amarelo no Brasil. In: RUGGIERO, C. (Ed.) Maracujá. Ribeirão Preto: Legis Summa, 1987. p.146159.

YASUTANI, I.; OZAWA, S.; NISHIDA, T.; SUGIYAMA, M.; KOMAMINE, A. Isolation of temperature-sensitive mutants of Arabidopsis thaliana that are defective in the redifferentiation of shoots. Plant Physiology, v.105, p.815822, 1994.

YE, X.; AL-BABILI, S.; KLÖTI, A.; ZHANG, J.; LUCCA, P.; BEYER, P.; POTRYKUS, I. Engineering the provitamin A ( $\beta$-carotene) biosynthetic pathway into (carotenoid-free) rice endosperm. Science, v.287, p.303-305, 2000.

ZHANG, P.; LEGRIS, G.; COULIN, P.; PUONTI-KAERLAS, J. Production of stably transformed cassava plants via particle bombardment. Plant Cell Reports, v.19, p.939-945, 2000. 